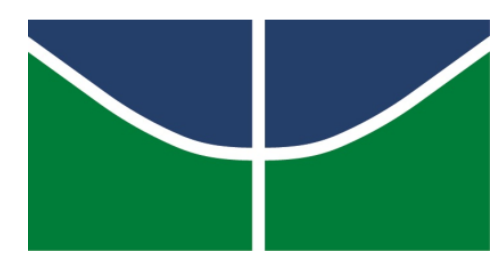

UNIVERSIDADE DE BRASÍLIA (UnB)

FACULDADE DE ECONOMIA, ADMINISTRAÇÃO E CONTABILIDADE DEPARTAMENTO DE ECONOMIA MESTRADO EM ECONOMIA DO SETOR PÚBLICO

Dayson Pereira Bezerra de Almeida

EXPANSÃO DO CRÉDITO E INFLAÇÃO NO BRASIL: uma análise econométrica

Brasília 
Dayson Pereira Bezerra de Almeida

\title{
EXPANSÃO DO CRÉDITO E INFLAÇÃO NO BRASIL: uma análise econométrica
}

\begin{abstract}
Dissertação apresentada ao Departamento de Economia da Faculdade de Economia, Administração e Contabilidade da Universidade de Brasília, como requisito parcial para a obtenção do título de Mestre em Economia.
\end{abstract}

Orientador: Prof. Dr. Paulo Springer de Freitas

\section{Brasília}


[espaço reservado à ficha catalográfica] 


\section{EXPANSÃO DO CRÉDITO E INFLAÇÃO NO BRASIL:}

uma análise econométrica

Dissertação - Mestrado em Economia do Setor Público

$2^{\circ}$ Semestre de 2016

Dayson Pereira B. de Almeida

Banca Examinadora:

Prof. Dr. Paulo Springer de Freitas (UnB)

Prof $^{\mathrm{a}}$. Dr ${ }^{\mathrm{a}}$. Maria Eduarda Tannuri-Pianto (UnB)

Prof. Dr. Tito Belchior Silva Moreira (UCB)

Brasília, 19 de setembro de 2016. 
Por ela e para ela, amada esposa e incondicional companheira, Patrícia. 


\section{Resumo}

Esta pesquisa investigou, para o caso do Brasil, os impactos sobre a inflação derivados do aumento no volume de crédito concedido pelo sistema financeiro, diante da sensível ascensão no saldo das operações dessa natureza observada nos últimos anos. A recente expansão creditícia apresentou-se como uma das medidas que conformaram a chamada "Nova Matriz Macroeconômica" - política que se sucedeu ao regime caracterizado pelo tripé macroeconômico (austeridade fiscal, livre flutuação cambial e metas para a inflação). Por seu turno, a teoria do canal do crédito ressalta o potencial do crédito como um mecanismo amplificador dos efeitos de alterações no mercado monetário sobre a economia real, tanto pela via do canal dos empréstimos bancários (bank lending channel), quanto por meio do canal do balanço dos devedores (balance sheet channel). Tendo em conta referidos fundamentos teóricos e a evidência empírica de existência e funcionamento do canal de crédito no Brasil, ao lado da mencionada elevação no nível de crédito na última década, lançou-se mão de um modelo irrestrito de correção de erros (UECM) - fazendo uso de dados trimestrais de setembro de 1999 a setembro de 2015 - para testar a hipótese de cointegração entre as séries temporais de crédito e inflação, incluindo-se outras variáveis relevantes para a análise do equilíbrio de longo prazo. Estimou-se, ademais, modelo vetorial de correção de erros (VECM) para exame das funções resposta-impulso e da decomposição da variância dos erros de previsão, buscando descrever a dinâmica de curto prazo do relacionamento entre as variáveis. Os resultados indicam que, no curto prazo, uma perturbação positiva no crédito relaxaria parcialmente a restrição de liquidez, possibilitando um aumento do nível de despesas de firmas e famílias, o que estimula a demanda agregada e eleva o hiato do produto, de modo que elevações no volume de crédito têm impacto positivo e significante sobre a inflação. Para o longo prazo, as evidências obtidas sugerem que um aumento no nível de crédito acarreta pressões inflacionárias, confirmando, para o país, o caráter nocivo de excessos na política creditícia. Resultados adicionais apontam que o crédito reage negativamente a uma elevação na taxa básica de juros da economia - conforme previsões teóricas -, e sinalizam certa leniência da política monetária sob a égide da "Nova Matriz Macroeconômica", dado que a taxa Selic não respondeu com a tempestividade e magnitude necessárias aos movimentos inflacionários provocados pela aceleração no volume de crédito ofertado na economia.

Palavras-chave: Inflação. Crédito. Brasil. UECM. VECM. 


\begin{abstract}
This study investigates, in the case of Brazil, the response of inflation rate to substantial increase that took place in the past few years in the amount of credit made available by the financial system. The recent expansion of credit reflects one of the policies adopted in the so called "New Macroeconomic Matrix" - a policy instrument adopted subsequently to the regime characterized by the macro-economic tripod (fiscal austerity, floating exchange rate, and inflation targets.) The credit channel theory, in turn, highlights credit's potential as a mechanism for amplifying the effects upon the real economy of changes in the money market, both via bank lending channel and balance sheet channel. Considering the theoretical foundations as well as empirical evidence pointing to the existence and functioning of the credit channel in Brazil - in addition to the aforementioned rise in credit offerings in the past decade - this study employs an Unrestricted Error Correction Model (UECM), with quarterly data ranging from September 1999 to September 2015, to test the hypothesis of the co-integration among credit and inflation time series, which include other variables relevant to the analysis of long-term equilibrium. Furthermore, this work estimates the Vector Error Correction Model (VECM) in order to examine impulse-response functions and the decomposition of forecast error variance, seeking to describe the short-term dynamics of the relationships amongst the variables. The results indicate that, in the short term, a positive disturbance in credit partially loosens liquidity restrictions, enabling spending increases among businesses and families, which stimulates aggregate demand and raises the output gap, such that increases in the volume of credit positively and significantly impact inflation rates. Evidence obtained in this study suggest that in the long-term an increase in credit levels generates inflationary pressures, confirming, for the country in question, the damaging effects of excesses committed by credit policies. Additional findings indicate that credit reacts negatively to elevations in the economy's basic interest rate - in conformity with theoretical predictions - and signal some degree of leniency in the monetary policies adopted under the auspices of the "New Macroeconomic Matrix," given the fact that Brazil's basic interest rate (or Selic) has not responded with the timeliness and intensity necessary to tackle the inflationary movements caused by the acceleration in the volume of credit offered in the economy.
\end{abstract}

Key words: Inflation. Credit. Brazil. UECM. VECM. 


\section{LISTA DE TABELAS}

Tabela 2.1 - Desonerações Tributárias - Nova Matriz Macroeconômica................................. 19

Tabela 4.1 - Descrição das séries temporais e fontes de dados .............................................. 41

Tabela 4.2 - Estatística descritiva das variáveis. Amostra: 1999.3 - 2015.3 ........................... 42

Tabela 5.1 - Resultados do teste para análise de cointegração (bounds test approach)...........53

Tabela 5.2 - Coeficientes de curto prazo ECM. Variável dependente: $\Delta \pi_{\mathrm{t}}$. Período: 1999.3-

$2015-3$ 53

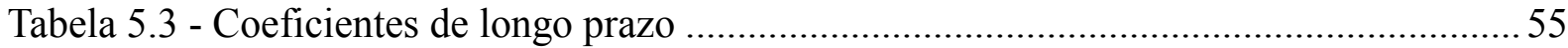

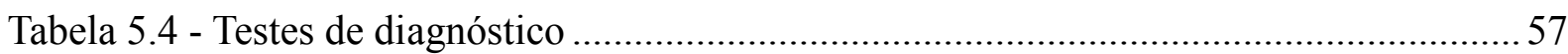

Tabela 5.5 - Decomposição da variância do erro de previsão ................................................. 62

Tabela A.1 - Resultados dos testes de raiz unitária Augmented Dickey Fuller (ADF) ............ 77

Tabela A.2 - Resultados dos testes de raiz unitária Phillips-Perron (PP) .............................. 77

Tabela A.3 - Resultados dos testes de raiz unitária Kwiatkowski-Phillips-Schmidt-Shin

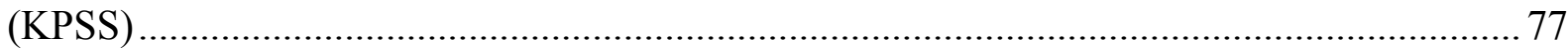

Tabela A.4 - VECM - Raízes do polinômio característico ...................................................... 78

Tabela A.5 - Função impulso-resposta generalizada .............................................................. 79 


\section{SUMÁRIO}

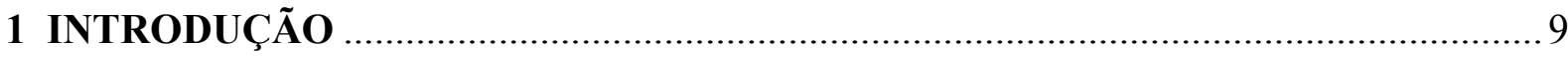

2 POLÍTICA ECONÔMICA BRASILEIRA RECENTE .............................................. 12

2.1 Do tripé à nova matriz macroeconômica ................................................................ 12

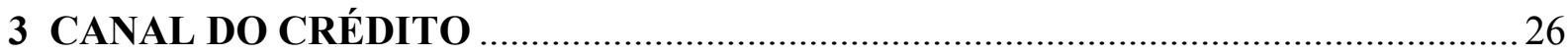

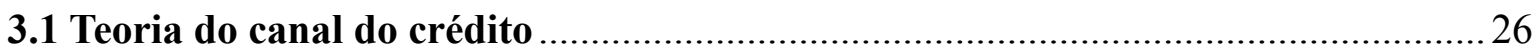

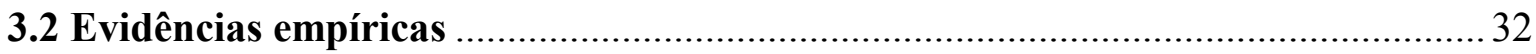

3.3 Liquidez e demanda de firmas e famílias ........................................................... 36

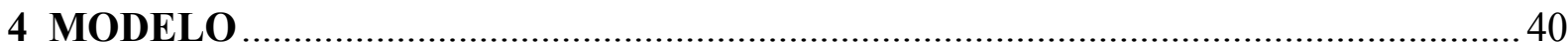

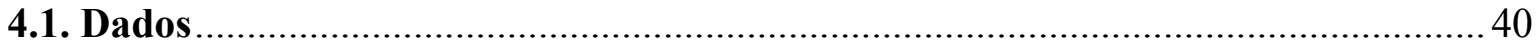

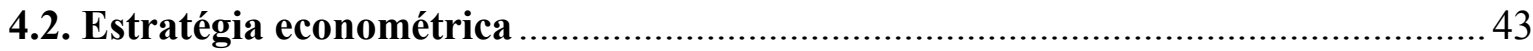

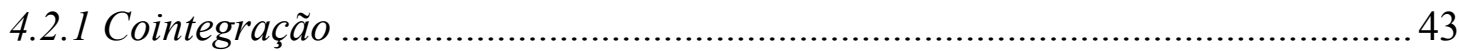

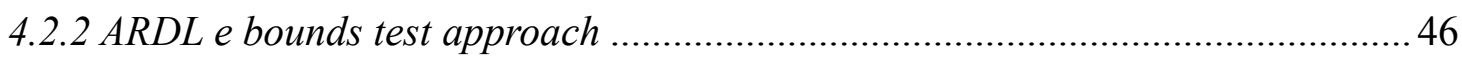

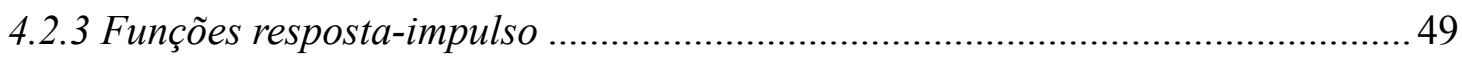

4.2.4 Decomposição da variância dos erros de previsão ............................................ 51

5 RESULTADOS

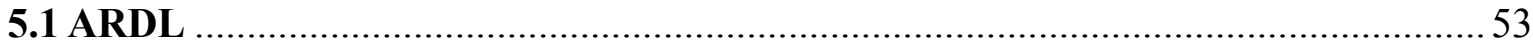

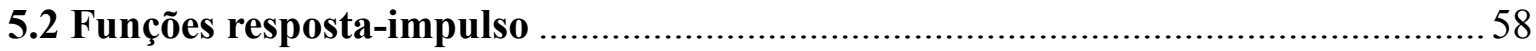

5.3 Decomposição da variância dos erros de previsão .................................................... 62

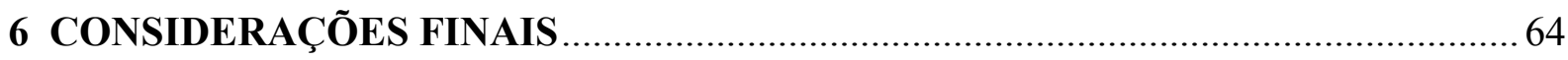

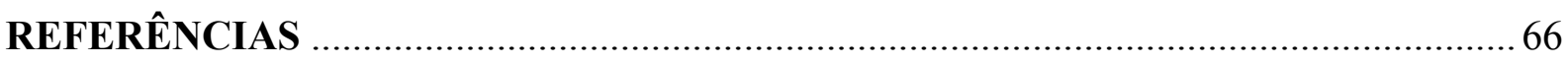

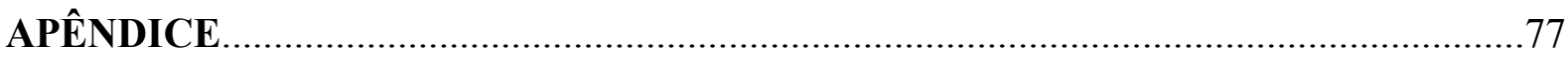




\section{INTRODUÇÃO}

A teoria do canal do crédito aponta a importância dos movimentos no mercado de crédito - sejam oriundos da capacidade de endividamento de firmas e famílias (lado dos demandantes), sejam decorrentes das possibilidades de concessão por parte de emprestadores (lado da oferta) - no contexto dos mecanismos de transmissão da política monetária (BERNANKE, 1992). Oferece, assim, uma explicação que se alia à tradicional visão do canal de demanda agregada (via alterações na taxa de juros) para auxiliar na compreensão da magnitude e do timing dos efeitos das ações da referida política sobre o curso da economia real.

Desenvolvida a partir da década de 80 do século passado, a visão do canal do crédito procura investigar o relacionamento entre moeda e atividade econômica e qualifica o debate ao propor novas possibilidades de leitura ao funcionamento das engrenagens pertinentes às ações de política monetária. Para além de trabalhos teóricos, diversos estudos deram suporte empírico ao canal do crédito, oferecendo evidências do funcionamento do bank lending channel e do balance sheet channel em diversas economias e em diferentes épocas (OLINER e RUDEBUSCH, 1996; KASHYAP e STEIN, 2000; CICARELLI et al, 2010; dentre vários outros). Na literatura nacional, Souza-Sobrinho (2003) e Oliveira e Andrade Neto (2008), por exemplo, corroboram a existência e a importância do canal de empréstimos bancários na transmissão da política monetária brasileira.

Essa linha de pesquisa deu novo impulso a pesquisas dedicadas ao processo de criação de crédito e seus efeitos sobre o produto (CALZA e SOUZA, 2005; OZCELBI, 2012; AVDJIEV e ZENG, 2014, por exemplo). Em particular, perquiriu-se eventual relação entre os movimentos creditícios e a inflação observada em determinada economia, buscando-se quantificar os impactos observados (veja-se, e.g., TANG, 2001; ESLAMLOUEYAN e DARVISHI, 2007; MOINESCU, 2012). Referidos estudos, em síntese, indicam a existência de relacionamento não desprezível entre inflação e seus principais determinantes, incluso o volume de crédito concedido pelo sistema financeiro. Para o Brasil, Catão e Pagan (2009) registram que choques de crédito têm sensíveis efeitos sobre produto e inflação.

Dado o contexto acima delineado, voltam-se as atenções para o cenário brasileiro. É cediço que, formalmente, o Brasil adota um regime de metas para inflação desde 1999. Ao lado do compromisso com a austeridade fiscal e da livre flutuação cambial, as metas de inflação compõem o tripé de política econômica implementado no país na virada do século que, ao menos no discurso político, permanece vigente até os dias de hoje. 
É de se ressaltar, de outro lado, que a estratégia de crescimento do país posta em prática nos últimos anos foi orientada pela ampliação do mercado de consumo de massa, fiando-se no proeminente papel exercido pelos bancos públicos e na expansão do crédito para pessoas físicas (BRASIL, 2011). Lima e Ferreira (2012) afirmam que a expansão do crédito foi um desdobramento deliberado da política econômica do governo Lula. Com efeito, o crédito total saltou de 26,8\% do PIB, em 2001, para 48\%, em 2010 (BARBI, 2014a). Dados atualizados do Banco Central (BACEN) indicam que a relação alcançou $54,65 \%$ ao fim de 2014.

As instituições financeiras controladas pelo setor público (ou bancos públicos, a bem da simplicidade, adotando-se, doravante, quaisquer dos termos indiscriminadamente), máxime na esfera federal, desempenharam um papel proeminente nesse contexto. Com efeito, de acordo com o Banco Central, se o saldo de crédito (livre + direcionado) concedido por bancos públicos equivalia a $35 \%$ do total no encerramento do exercício de 2001, a participação de tais instituições saltou para 56\% ao final de setembro de 2015. O fenômeno explicita a "estatização" do crédito que o Brasil experimentou no período em discussão.

Noutro aspecto, a última oportunidade em que a inflação acumulada em doze meses, medida pelo IPCA, esteve abaixo do centro da meta do Bacen ( $4,5 \%$ a.a.) deu-se em agosto de 2010: naquele mês, a variação anual do índice marcou 4,29\%, segundo o Instituto Brasileiro de Geografia e Estatística (IBGE). Findo citado exercício, a inflação efetiva fechou em 5,91\% a.a. e, desde então, os resultados têm permanecido consistentemente nesse patamar ou acima, atingindo 10,67\% a.a. em 2015 - o que obrigou o Banco Central a divulgar Carta Aberta ao Ministro de Estado da Fazenda, nos termos do art. $4^{\circ}$, parágrafo único, do Decreto 3.088/1999, explicitando os motivos que levaram ao descumprimento da meta de inflação fixada para o exercício e as medidas que seriam adotadas para assegurar o cumprimento da meta nos anos subsequentes.

A sobreposição temporal observada entre a sensível e continuada expansão do crédito e a persistência da pressão inflacionária, ao lado da perspectiva teórica e evidências empíricas acima comentadas, mostra a relevância do estudo da eventual relação entre tais fenômenos. Deve-se, portanto, questionar em que medida o aumento da oferta de crédito pode influenciar o processo sustentado de elevação de preços, especialmente diante da constatação da relevância que o canal de crédito tem assumido perante os ciclos econômicos do país (MINELLA e SOUZA-SOBRINHO, 2011). É esta, portanto, a razão motivadora deste trabalho, na esteira de pesquisas análogas (BARBI, 2014b; FONSECA, 2014). 
Objetiva-se, destarte, verificar e mensurar os possíveis impactos do crédito sobre a inflação, no curto e longo prazos, controlando-se para determinadas variáveis recorrentemente lembradas pela literatura nacional. Para tanto, com dados do período entre 1999 e 2015, foi adotada a seguinte estratégia econométrica:

a) a priori, visando a testar a hipótese de que crédito e inflação estão relacionados no longo prazo, recorreu-se à análise de cointegração entre as séries temporais, seguindo-se a abordagem proposta por Pesaran et al (2001), que sugerem a aplicação de um modelo irrestrito de correção de erros (UECM) capaz de testar tal hipótese, ainda que presente uma combinação de variáveis com diferentes graus de integração, conforme identificado em testes preliminares de estacionariedade;

b) procedeu-se à análise das funções resposta-impulso (FRI) visando testar a existência de relacionamento e descrever a dinâmica de curto prazo entre crédito e inflação;

c) efetuou-se, ainda, o exame da decomposição da variância dos erros de previsão para mensurar a influência, no curto prazo, dos movimentos no crédito sobre a inflação e as demais variáveis relevantes.

Os resultados do exercício empreendido confirmam a hipótese de relacionamento entre crédito e inflação: no curto prazo, um choque de crédito é inflacionário; movimentos no saldo de crédito concedido pelo sistema financeiro explicam 11,6\% do erro de previsão da variância da inflação no horizonte de doze trimestres. Ademais, também na situação de equilíbrio (longo prazo), o índice de preços acompanha variações no nível absoluto de crédito ofertado na economia. Resultados adicionais indicam, ainda, que o crédito reage negativamente a uma elevação na taxa básica de juros da economia - conforme previsto pela teoria do canal do crédito -, e sinalizam certa leniência da política monetária diante da escalada do crédito a partir de 2011.

A par desta introdução, que constitui o Capítulo 1, o texto subdivide-se em mais cinco capítulos. No segundo, oferece-se breve revisão sobre a política econômica brasileira recente, desde a adoção do regime de metas para inflação até a conformação da assim chamada "Nova Matriz Macroeconômica”. O capítulo 3 aborda o canal do crédito, seus pressupostos teóricos e evidências empíricas, aduzindo considerações sobre a importância da liquidez para o nível de demanda de firmas e famílias. Em seguida, o texto dedica-se aos aspectos metodológicos do trabalho: detalham-se o conjunto de dados utilizados e a estratégia econométrica que balizou a pesquisa. O quinto capítulo expõe os resultados alcançados e, por fim, apresentam-se as considerações finais. 


\section{POLÍTICA ECONÔMICA BRASILEIRA RECENTE}

Este capítulo discutirá, brevemente, as características e fundamentos da política econômica brasileira nos últimos anos, com destaque para a transição entre o regime caracterizado pelo tripé macroeconômico e as medidas que conformaram a nova matriz macroeconômica implementada no governo Dilma Roussef.

No contexto da pesquisa aqui proposta, a reconstrução da narrativa acerca da economia do País no período justifica-se pela potencial relevância do canal do crédito para a calibragem das ações do Banco Central em um regime de metas de inflação. Além disso, conforme se verá adiante, a expansão creditícia patrocinada no escopo da nova matriz sugere que o canal do crédito tenha alcançado ainda maior centralidade como mecanismo de transmissão das ações de política monetária no passado recente.

\subsection{Do tripé à nova matriz macroeconômica}

Vão-se mais de quinze anos desde que, na esteira da implementação do Plano Real e premido pelas circunstâncias do momento - crise fiscal e expressivos déficits na conta corrente - o Brasil adotou formalmente, em 1999, um regime de política econômica que passou a ser tradicionalmente referido como o "tripé macroeconômico". Os três pilares referenciados pelo termo são assim sintetizados (AVERBURG e GIAMBIAGI, 2000):

a) austeridade fiscal;

b) livre flutuação cambial; e

c) metas para a inflação (inflation target).

O compromisso com a austeridade, na forma de resultados fiscais superavitários, estava inserido no contexto de um acordo firmado com o Fundo Monetário Internacional (FMI) ao final de 1998 (AVERBUG e GIAMBIAGI, 2000). Tal compromisso fora, posteriormente, reafirmado e reforçado mediante a edição da Lei Complementar 101/2000, popularmente conhecida como Lei de Responsabilidade Fiscal, que possui o objetivo declarado de assegurar o equilíbrio das contas públicas (BRASIL, 2000).

A livre flutuação do câmbio veio substituir o modelo até então vigente, em que a autoridade monetária intervinha no mercado de divisas para garantir que a cotação da moeda estrangeira permanecesse dentro de certo intervalo preestabelecido, conforme requerido pela estratégia de ancoragem que caracterizou a gestão cambial durante os primeiros anos do Plano 
Real (SOARES, 2006). Com a mudança do regime cambial, o Banco Central ganharia graus de liberdade para utilizar a taxa de juros no controle da inflação.

O regime de metas de inflação, por sua vez, consiste em um arcabouço para a política monetária em que ocorre o anúncio público da taxa de inflação a ser perseguida em um horizonte temporal específico (WALSH, 2010). Segundo Carrara e Corrêa (2012, p. 443):

Durante a década de 1990, o regime de metas de inflação tornou-se um instrumento utilizado por vários países que procuravam institucionalizar a busca da estabilidade de seus preços, dar maior transparência à condução da política monetária, eliminar os problemas ligados ao viés inflacionário e, por conseguinte, fazer com que a sua autoridade monetária tenha maior credibilidade.

Os autores aduzem, ainda, que a publicação periódica das metas visa à "transparência das ações dos formuladores de política, e ao comprometimento com a estabilidade de preços e com o cumprimento das metas" (2012, p. 443). Para Averbug e Giambiagi (2000, p. 29), citado compromisso explícito representou uma "experiência inédita no Brasil (...) verdadeira revolução cultural".

Formalmente, o regime de metas foi introduzido no país pelo Decreto $\mathrm{n}^{\mathrm{o}} 3.088$, de 21 de junho de 1999, que estabeleceu a sistemática de "metas para a inflação" como diretriz para fixação do regime de política monetária (BRASIL, 1999a). Em seguimento, o Conselho Monetário Nacional (CMN) editou a Resolução 2.615, fixando as metas para a inflação e seus respectivos intervalos de tolerância, bem como o índice de preços a que se aplicam, para os anos de 1999 e os dois seguintes (BRASIL, 1999b).

O tripé e seus elementos, brevemente descritos acima, avalizam a ideia prevalecente (BLANCHARD et al, 2010) de que a política monetária deve preocupar-se unicamente com a inflação - tendo como principal instrumento a taxa básica de juros de curto prazo - ao lado da neutralidade ou secundarismo da política fiscal. Nesse arcabouço, a autoridade monetária somente deve considerar movimentos cambiais à medida que estes se tornem relevantes em termos de impactos sobre a variável de interesse. Da mesma forma, o Banco Central não deve tomar decisões de política monetária tendo outros objetivos, como o crescimento de curto prazo do PIB.

Para Morais e Saad-Filho (2011), o arranjo de política macroeconômica em questão, implementado durante o segundo mandato do presidente Fernando Henrique Cardoso, estendeu-se, sem grandes perturbações, ao longo do primeiro mandato do presidente Luiz Inácio Lula da Silva (2003-2006). Oreiro (2014, p. 119) faz o levantamento de um balanço das realizações alcançadas sob a égide do assim chamado tripé macroeconômico e oferece a seguinte avaliação acerca dos resultados da política em comento: 


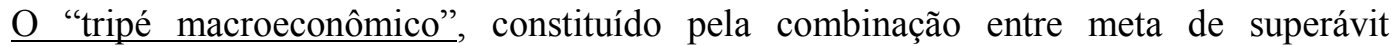
primário, câmbio flutuante e metas de inflação, foi muito bem-sucedido no que se refere a alcançar os objetivos para os quais foi pensado (...) a saber: estabilizar/reduzir a relação dívida pública/PIB, garantir a estabilidade da taxa de inflação e permitir que a política monetária fosse conduzida com vistas ao atendimento de objetivos domésticos, em vez de ser desenhada em função das necessidades de ajuste do balanço de pagamentos (grifamos).

Haveria, contudo, nos anos seguintes, certo distanciamento do cerne da política consubstanciada pelo tripé macroeconômico. Modenesi et al (2013, p. 175) apontam o ano de 2007 como marco inicial para um processo de mudanças que "aproximou a política econômica de propostas pós-keynesianas”. Barbosa e Souza (2010, p. 14 e 11), por sua vez, argumentam que, já em 2006, o governo Lula "optou mais claramente por uma política econômica desenvolvimentista", que "procurou testar na prática a existência de tais limites [ao produto potencial], de forma a ultrapassá-los".

Há, portanto, certa imprecisão acerca do exato momento em que a gestão macroeconômica nacional passou a contar com "certa diversidade de objetivos e de instrumentos" (MODENESI et al, 2013, p. 175); as opiniões convergem, entretanto, para atestar uma mudança de rumos na condução da política econômica prevalecente no início do século. Oreiro $(2015$, p. 1) reforça a percepção: “ao final do primeiro mandato do Presidente Lula (...) o 'tripé macroeconômico', embora mantido, começa a ser flexibilizado".

A “inflexão do Governo Lula" teve como premissa a maior participação do Estado na promoção do desenvolvimento econômico - quer nos investimentos diretos, quer na regulação dos mercados. Conforme a visão desenvolvimentista, "O financiamento do aumento no investimento público (...) poderia ocorrer tanto por receitas tributárias quanto por emissão de dívida pública” (BARBOSA e SOUZA, 2010, p. 13), assumindo-se que o déficit daí decorrente seria absorvido pelo crescimento econômico esperado.

A nova abordagem de política econômica envolveu a adoção de medidas monetárias e fiscais de estímulo ao crescimento, ao lado da ampliação das transferências de renda para as famílias como instrumento de expansão da demanda agregada. A esse respeito, citam-se a sensível elevação no salário mínimo, observada a partir de 2006, os diversos incentivos tributários setoriais concedidos e a ampliação do crédito ao setor privado (BARBOSA e SOUZA, 2010). Para este último, contribuíram, em um primeiro momento, a redução na taxa real de juros e a simplificação dos procedimentos de recuperação de crédito, com o advento da nova Lei de Falências (Lei 11.101/2005), além da introdução e "crescimento acelerado [das operações de crédito consignado], a partir de 2004" (BARBOSA e SOUZA, 2010, p. 7). 
A expansão do crédito - como, de resto, ocorreria com boa parte das medidas acima referidas no contexto desenvolvimentista - seria, contudo, alçada a outro patamar no contexto da crise financeira mundial deflagrada em 2008. Diante do cenário adverso instaurado na ocasião, observou-se acentuada queda no volume de concessão de crédito por parte do setor bancário privado. "Nesse momento, os bancos públicos e de desenvolvimento entraram agressivamente nesse mercado, para restaurar a liquidez das empresas e das famílias, manter o giro das atividades daquelas e contribuir para a reestruturação das dívidas de ambas" (MODENESI et al, 2013, p. 173).

Barbosa e Souza (2010, p. 25-26) detalham que, abastecido por linha de crédito concedida pela união, o BNDES intensificou a oferta de financiamentos ao setor produtivo; no mesmo sentido, Caixa Econômica e Banco do Brasil disponibilizaram capital de giro aos setores com maior dificuldade de liquidez. As instituições financeiras controladas pela União, no papel de emprestadores de penúltima instância e sob orientação do governo federal, reduziram seus spreads de taxa de juro e aceleraram a concessão de crédito. Os autores pontuam que "entre setembro de 2008 e julho de 2009, os bancos públicos aumentaram sua oferta de crédito em $33 \%$, enquanto as instituições privadas nacionais cresceram $4 \%$ e as instituições estrangeiras 1,5\%".

Nesse sentido, "enquanto o BNDES garantia a reestruturação das dívidas e o funding de longo prazo de diversas empresas, BB e Caixa garantiam a sanidade das contas das famílias e o giro das empresas" (MODENESI et al, 2013, p. 174).

A par do estímulo à política creditícia, Barbosa e Souza (2010) apontam, ainda, outras ações - de cunho emergencial ou estrutural - adotadas durante a turbulência financeira do final da década. No primeiro grupo estariam intervenções do Banco Central voltadas ao mercado de câmbio, com vistas a atenuar a desvalorização da moeda doméstica, e à redução dos depósitos compulsórios, além de um corte substancial na taxa Selic (de 13,75\% em setembro/2008 para 8,75\% em julho/2009). Entre as medidas estruturais, assim denominadas por prolongarem-se além da crise, os autores indicam a mudança no patamar na taxa de juros reais da economia (de 9\% para 5\%), aproveitando-se do recuo da inflação decorrente do desaquecimento da produção no país.

Do lado dos estímulos fiscais, Araújo e Gentil (2011) citam desonerações tributárias que beneficiaram os setores automotivo, de eletrodomésticos, de material de construção e moveleiro, viabilizadas mediante a redução da meta de superávit primário para 2009 (de 4,3\% para $2,5 \%$ do PIB). 
Mello (2015, p. 21) arremata: "Com o advento da crise, o Brasil utilizou-se de instrumentos pouco ortodoxos de política econômica”, citando os vetores da estratégia que se voltou ao crescimento impulsionado pela demanda: ampliação do crédito subsidiado pelos bancos estatais, aumento dos gastos públicos e concessão de incentivos ao consumo. Em resumo: "A crise financeira de 2008 (...) levou a um aprofundamento do processo de flexibilização do "tripé macroeconômico", estabelecendo as bases de um novo regime de política macroeconômica no Brasil" (OREIRO, 2015, p. 11).

Esse novo regime, calcado em redistribuição de renda, aumentos salariais e expansão do crédito, teria por objetivos (OREIRO, 2015, p. 16-17):

manter a estabilidade da taxa real de câmbio, aumentar a participação dos salários na renda nacional, garantir a estabilidade da taxa de inflação no longo-prazo, induzir um crescimento robusto do produto real e viabilizar um forte aumento da demanda agregada doméstica por intermédio de um crescimento acelerado dos gastos primários do governo.

Contudo, prossegue o professor, "esses objetivos não são mutuamente consistentes, ou seja, não podem ser obtidos simultaneamente" (2015, p. 16), evidenciando a ausência ou impossibilidade de coordenação entre as políticas monetária, salarial, fiscal e cambial, e suas respectivas metas.

De fato, explica-se:

a expansão fiscal e o aumento da participação dos salários na renda são incompatíveis com os objetivos de estabilidade da taxa real de câmbio e estabilidade da taxa de inflação. Isso porque a forte expansão da demanda agregada doméstica num contexto de elevação do custo unitário do trabalho e crescimento acelerado do produto real resulta na aceleração da taxa de inflação, caso o governo decida impedir a valorização da taxa real de câmbio resultante dessa combinação de políticas. Por outro lado, se a decisão do governo for manter a inflação estável e dentro das metas definidas pelo Conselho Monetário Nacional, a taxa de juros nominal e real de juros deverá ser mantida em patamares elevados, induzindo assim uma forte entrada de capitais externos, a qual termina por produzir a continuidade da apreciação da taxa real de câmbio (OREIRO, 2015, p. 16).

Daí as críticas oferecidas por referido autor, que alude ao modelo por “desenvolvimento inconsistente", compreendendo o período entre os anos de 2008 a 2011 (OREIRO, 2015, p. 17).

Por seu turno, Mello (2015, p. 21) aponta que, superada a crise em 2010, “o país voltou a apostar no tripé macroeconômico e no recrudescimento do aperto fiscal como forma de reduzir as expectativas inflacionárias e a taxa de juros". Não obstante, é precisa a avaliação de Modenesi et al (2013, p. 177), para quem, “os tempos de reinado absoluto do tripé de política econômica parecem ter ficado para trás. (...) apesar de o tripé não ter sido abandonado, a sua era de ouro já passou”. 
Com efeito, entre junho de 2010 e agosto de 2011, o Banco Central patrocinou uma contração monetária em resposta às pressões inflacionárias surgidas em virtude do overheating da economia nacional, que crescera 7,5\% em 2010: verificou-se um aumento de 300 pontos base na Selic, no período em questão. Tal movimento, contudo, não foi suficiente para avalizar um retorno absoluto ao regime ortodoxo vigente até 2005. Consoante já ressaltado, mesmo na nova conformação, a política monetária continuaria a buscar uma inflação estável, mas, doravante, o faria tendo em conta um maior prazo de convergência para o centro da meta (OREIRO, 2015, p.16).

Ademais, ainda em 2011 observar-se-ia uma reversão no ciclo de ascensão da taxa de juros. Esse fato - argumenta-se - revelou a transmudação, ainda que implícita, daquilo que representa a taxa básica de juros da economia: a Selic passara de instrumento para objetivo de política econômica, com todos os prejuízos disso resultantes.

Não pode ser outra a conclusão a partir da leitura de Bresser-Pereira (2013, p. 14): "Sob a presidência de Alexandre Tombini, o Banco Central do Brasil voltou a se identificar com os interesses nacionais. (...) Assim apoiada, a presidente logrou reduzir substancialmente a taxa de juros em termos nominais e reais, que afinal caiu para cerca de $3 \%$ ao ano" (grifamos). Naquela oportunidade, predominava entre os gestores do alto escalão do governo federal a avaliação de que o nível de juros observado no país era disfuncional e causador de problemas mais profundos:

A despeito das substanciais melhorias ao longo da última década, que colocaram o Brasil como um novo protagonista na cena econômica internacional, as taxas de juros ainda vinham se sustentando em níveis excessivamente elevados ao longo do tempo. Era uma anomalia que não se justificava (...).

As taxas elevadas estão na gênese de duas outras grandes distorções na economia, a saber, câmbio valorizado e carga fiscal elevada, que levam à má alocação de recursos e a um menor crescimento da economia. Juros elevados atraem capital externo para a arbitragem, valorizando o real (especialmente em um ambiente de afrouxamento quantitativo em países desenvolvidos) e diminuindo a competitividade da produção brasileira. Por outro lado, o alto serviço da dívida pública, que chegou a consumir 5,8\% do PIB em juros até o ano passado, exige uma arrecadação maior de impostos, para atingir as metas fiscais estabelecidas pelo governo (...).

Nesse sentido, colocava-se como absolutamente estratégico remover, ou pelo menos minimizar, a distorção que havia nos dois principais preços do país: juros e câmbio (MANTEGA, 2012, p. 1) (grifamos).

Assim, alçada à condicionante do desenvolvimento nacional, a taxa básica de juros passou a ser adereçada como problema que demandava urgente tratamento. Daí se falar em transmudação da Selic de instrumento para objetivo de política monetária. Oreiro $(2015$, p. 2), em interpretação análoga a aqui oferecida, ao caracterizar o novo regime de política econômica, cita a "redução da autonomia operacional do Banco Central, o qual teria sido 
induzido pela Presidência da República a iniciar um ciclo de redução da taxa de juros no segundo semestre de 2011 apesar das pressões inflacionárias latentes na economia brasileira" (grifamos).

O novo regime de política econômica a que faz referência o autor viria a ser conhecido como "Nova Matriz Macroeconômica", assim denominado pelo então Ministro Mantega, e seria caracterizado pela combinação entre juros baixos, câmbio "competitivo" e política fiscal “amigável” ao investimento público (OREIRO, 2015, p. 2). Segundo o então Secretário de Política Econômica do Ministério da Fazenda, o tripé que compunha a nova matriz traduzirse-ia em (i) um ambiente de negócios em que são prevalentes juros baixos, tendo a queda de 5,25 pontos percentuais da Selic, entre agosto de 2011 e novembro de 2012, caminhado nesse sentido; (ii) uma taxa de câmbio mais competitiva, em favor de maiores produção e emprego; e (iii) uma "consolidação fiscal amigável ao investimento e ao crescimento": políticas físcais anticíclicas traduzidas em desonerações do investimento e da produção (HOLLAND, 2012). Propalava-se, na oportunidade, "uma alteração qualitativa na gestão da política econômica, expressa numa melhor coordenação das políticas monetária, cambial e fiscal" (CASTRO et al, 2013, p. 9).

O ano de 2012 marcaria, assim, o momento em que "o governo da Presidente Dilma Rouseff tentou se libertar definitivamente do 'tripé macroeconômico', substituindo-o por uma "nova matriz macroeconômica"” (OREIRO, 2015, p. 2). Ao final daquele exercício, o então Ministro da Fazenda, Guido Mantega, publicou artigo no jornal Valor Econômico, intitulado "O primeiro ano da nova matriz econômica" (2012), referindo-se a diversas medidas que compunham o modelo em comento: queda na taxa de juros, desonerações tributárias, programa de investimentos e concessões públicas, redução do preço da energia elétrica e disponibilização de R 100 bilhões em crédito a juros subsidiados, por intermédio do Banco Nacional de Desenvolvimento Econômico e Social (BNDES). À exceção da queda na taxa de juros, já abordada anteriormente, tais medidas são detalhadas a seguir.

No que concerne às desonerações tributárias, foram beneficiados diversos setores (mais de quarenta, no caso da desoneração da folha de pagamentos), gradativamente, com o objetivo de aumentar a competitividade da economia. De acordo com o relatório "Economia Brasileira em Perspectiva", publicado pelo Ministério da Fazenda, "as desonerações tributárias em 2012 foram superiores a R $\$ 40$ bilhões e, para 2013, a previsão é que superem os R\$ 70 bilhões, quase 2\% do PIB” (BRASIL, 2013, p.7). A tabela a seguir sumariza as medidas adotadas e os respectivos impactos orçamentários: 
Tabela 2.1 - Desonerações tributárias - Nova Matriz Macroeconômica

\begin{tabular}{lccc}
\hline \multicolumn{1}{c}{ Medidas } & \multicolumn{3}{c}{ Impacto (em R\$ bilhões) } \\
\cline { 2 - 4 } & 2012 & 2013 & 2014 \\
\hline Redução da CIDE a zero para gasolina e diesel & 8,9 & 11,4 & 11,4 \\
Redução do IPI (automóveis, caminhões, material de & 8,5 & 11,8 & 7,1 \\
construção, linha branca, BK, móveis, papel de parede etc.) & & & \\
Redução para zero do prazo de apropriação dos créditos & 7,6 & - & - \\
de PIS/ COFINS sobre aquisição de bens de capital & & & \\
Aumento dos limites das faixas de tributação & 5,7 & 5,9 & 6,5 \\
do SIMPLES e MEI & & 3,4 & 2,7 \\
REINTEGRA - Regime Especial de Reintegração de & 3,4 & & 24,7 \\
Valores Tributários para Empresas Exportadoras & 3,8 & 16,0 & 3,6 \\
Desoneração da folha de pagamentos & 2,8 & 3,6 & - \\
Redução do IOF sobre operações de crédito pessoa física & 1,1 & 0,6 & 1,0 \\
(de 3\% para 1,5\%) & 0,5 & 1,0 & 8,2 \\
Alíquota zero de PIS/COFINS sobre trigo e massas & - & 5,5 & 1,0 \\
Banda Larga - Redes & - & - & 22,0 \\
Desoneração da Cesta Básica & 2,2 & 10,9 & $\mathbf{8 8 , 2}$ \\
Aumento do Limite do Lucro Presumido & $\mathbf{4 4 , 5}$ & $\mathbf{7 0 , 1}$ & \\
Demais & &
\end{tabular}

Fonte: Ministério da Fazenda (BRASIL, 2013, p. 42)

As iniciativas referentes a investimentos do governo e concessões à iniciativa privada indicavam a centralidade do setor de infraestrutura na agenda das políticas públicas, visando a intensificar o aumento da Formação Bruta de Capital Fixo do país (FBKF) (BRASIL, 2013). Tais ações traduziram-se no Programa de Investimentos em Logística, que previa a aplicação de R $\$ 133$ bilhões na reforma e construção de $7.500 \mathrm{~km}$ de rodovias e de $10.000 \mathrm{~km}$ de ferrovias federais; nas concessões dos aeroportos de Brasília, Viracopos e Guarulhos, cujos investimentos planejados perfaziam R\$ 16 bilhões (BRASIL, 2012a, p. 32) e, numa segunda etapa, dos aeroportos de Confins e Galeão, que adicionariam mais de R\$ 11 bilhões ao montante. Ao lado disso, foram concebidos investimentos de $\mathrm{R} \$ 7,3$ bilhões para o fomento da aviação regional, com a implantação de 270 aeroportos distribuídos por todo o País.

Na mesma linha, citam-se, ainda: o projeto do Trem de Alta Velocidade (TAV), que teria investimentos de mais de $\mathrm{R} \$ 35$ bilhões; a licitação de 159 Portos Marítimos Organizados, com despesas de R \$ 54,6 bilhões; os investimentos planejados no setor de energia, mediante leilões para geração e transmissão de energia de fontes hidrelétrica, termelétrica, eólica, bimossa, etc., que totalizariam $\mathrm{R} \$ 148,1$ bilhões; a $1^{\mathrm{a}}$ rodada das licitações sob o regime de partilha de produção do Pré-Sal, em conjunto com outras intervenções no setor e petróleo e gás, com mais $\mathrm{R} \$ 80$ bilhões em investimentos (BRASIL, 2013). 
Quanto à redução das tarifas de energia elétrica, tal medida foi adotada no escopo do programa de reestruturação do setor elétrico, que, segundo Castro et al (2013, p. 10), teve por objetivo central "reduzir o custo da energia" - apontado como "uma das causas da perda de competitividade da economia nacional". A queda nas tarifas permitiria, por arrastamento, “baixar a inflação em valor estimado de 0,5\% em 2013" (CASTRO et al, 2013, p. 11).

Mediante a Medida Provisória 579/2012, posteriormente convertida na Lei 12.783/2013, determinou-se o fim da cobrança, nas tarifas, dos encargos referentes à Conta de Consumo de Combustíveis (CCC) e à reserva global de reversão (RGR), e a redução, para $25 \%$, do encargo relativo à Conta de Desenvolvimento Energético (CDE) (CASTO et al, 2013, p. 16). Além disso, "houve uma mudança de paradigma no que diz respeito à remuneração das hidroelétricas": para renovação das concessões de geração e transmissão, o governo ofereceu "condições comerciais nitidamente menos vantajosas que as que vinham sendo praticadas, financeiramente suficientes apenas para cobrir os custos de operação e manutenção com uma margem bastante estreita" (CASTRO et al, 2013, p. 18).

Citada intervenção no preço da energia representou, em média, uma redução de $18 \%$ nas tarifas para famílias, e de 32\% para empresas (BRASIL, 2013, p. 40).

A aludida disponibilização de R 100 bilhões em financiamentos via BNDES estava inserida no contexto de aceleração de aportes do Tesouro em favor do referido banco de desenvolvimento, observada desde 2009. Naquele exercício, visando a constituir fonte adicional de recursos para permitir o financiamento de projetos de investimento na carteira do BNDES, a Medida Provisória 453, posteriormente convertida na Lei 11.948/2009, autorizou a União a conceder crédito ao banco no valor de $\mathrm{R} \$ 100$ bilhões, mediante a emissão direta de títulos em favor daquela instituição financeira (BRASIL, 2009). Referida norma seria seguida por diversas outras - Medidas Provisórias 472/2009, 505/2010 e 526/2011, por exemplo com objetivos semelhantes e marcaria o início do processo de evolução de créditos junto ao BNDES na carteira de ativos do governo federal: de R\$ 6,6 bilhões ao final de 2007 para R\$ 514,5 bilhões no exercício de 2014 (BACEN).

Contudo, a expansão creditícia não seria observada apenas no setor de investimentos e infraestrutura: outros bancos públicos, máxime Banco do Brasil e Caixa Econômica Federal, "foram utilizados de forma anticíclica pelo governo (...) para prover crédito ao consumo" (SANTIN, 2013, p. 17-18), confirmando a estratégia de impulsionar a demanda agregada mediante firme ampliação do crédito. Modenesi et al aduzem (2013, p. 174):

Em 2012, houve nova rodada de expansão do crédito público, agora com objetivo mais amplo, o de restaurar não só a saúde financeira dos agentes, mas principalmente a 
demanda agregada, a partir do financiamento do consumo e do investimento. Isso foi acompanhado por uma cruzada contra as elevadas taxas de juros praticadas no mercado de crédito, iniciada com a redução dos spreads de BB e Caixa.

Nesse contexto:

Em dezembro 2012, o volume total de crédito no Brasil alcançou o montante de $\mathrm{R} \$ 2,36$ trilhões, atingindo $53,6 \%$ do PIB. O total de crédito não direcionado atingiu $\mathrm{R} \$ 1,39$ trilhão, com aumento anual de 13,5 p.p. O total do crédito direcionado, por sua vez, apresentou elevação ainda mais robusta, totalizando R \$ 968 bilhões e uma alta de 20,7 p.p. em relação ao mesmo período do ano anterior (BRASIL, 2013, p. 84).

Nesse passo, observou-se sensível alteração no martket share do setor bancário: o saldo das operações de crédito das instituições financeiras sob controle público, que representava $33,8 \%$ do total em dezembro de 2007 , acelerou para $47,8 \%$ em 2012 , chegando a $56 \%$ ao final de 2015, ou 30,36\% em relação ao PIB daquele exercício. Conforme Costa (2015, p. 5-6):

Graças à investida no crédito com forma de enfrentamento da crise financeira internacional de 2008, a Caixa é o banco que mais conquistou participação no mercado de crédito. O estoque de crédito do banco sextuplicou de junho de 2009 a dezembro de 2014 (...). Em operações de crédito, no final de 2014, a Caixa só estava abaixo do Banco do Brasil, que tinha R $\$ 645,0$ bilhões em sua carteira de crédito.

(...)

Desde 2008, quando o BNDES passou a receber aportes periódicos de recursos do Tesouro Nacional, da ordem de R $\$ 400$ bilhões, sua carteira de crédito saltou de $6,2 \%$ para $10,6 \%$ do PIB. As alocações orçamentárias para capitalizar as Instituições Financeiras Públicas Federais (IFPF) se transformam em reservas de empréstimos. Estes empréstimos multiplicam a quantidade de dinheiro na economia, exacerbando ciclos de expansão ou atuando contra-ciclo de queda da renda (grifamos).

De modo a possibilitar o agressivo aumento do crédito público oferecido por BB e Caixa, o Tesouro Nacional precisou, à semelhança do ocorrido com o BNDES, reforçar o capital de tais instituições financeiras. Tais aportes ocorreram de diversas maneiras. Destacam-se:

a) Concessões de créditos enquadráveis como instrumento híbrido de capital e dívida, que alcançaram R\$ 52,9 bilhões em dezembro 2015, quando, ao final de 2007, perfaziam R\$ 7,5 bilhões. Referidas fontes de recursos para ampliação dos limites operacionais dos bancos estatais foram viabilizadas mediante a edição de Medidas Provisórias, a exemplo das MPVs 470/2009, 581/2012, 600/2012 e 620/2013 (BRASIL, vários anos);

b) Aumento de capital mediante a transferência de ações ordinárias de emissão da Petróleo Brasileiro S.A. - PETROBRAS, bem como ações de diversas sociedades anônimas de capital aberto (Decretos 7.653/2011 e 7.880/2012, dentre outros) (BRASIL, vários anos).

Aqui, cabe um parêntesis acerca dos mecanismos utilizados para injeção de recursos nos bancos estatais que levaram a termo a estratégia de crescimento econômico alavancada 
pelo crédito público. Tais instrumentos, per si, já representariam tema robusto o suficiente a justificar um trabalho autônomo. Contudo, dada a relação umbilical entre os meios e o fim (e suas consequências) - este último objeto central desta pesquisa - julga-se oportuno fazer breve menção às disfunções derivadas da sistemática em comento, que fundamentou a expansão creditícia em estudo.

Em primeiro lugar, pontua-se a elevação da dívida bruta em decorrência da emissão direta de títulos em favor das instituições financeiras estatais, especialmente o BNDES. Entre dezembro de 2011 e dezembro de 2015, a dívida bruta do governo geral (DBGG) avançou de $51,3 \%$ para $66,2 \%$ do PIB, tendo a concessão de créditos aos bancos públicos desempenhado papel relevante em referido movimento. O agravamento da relação dívida bruta/PIB, indicando maior fragilidade financeira do governo e deterioração das contas públicas perante o mercado, alimenta a desconfiança acerca da solvência do Estado e tem como consequências naturais o aumento do custo dessa mesma dívida, vindo a desaguar em piora no ambiente de negócios, queda no nível e no fluxo de investimentos privados e contração da atividade econômica.

Aliás, na origem de tal engenharia - que, a um só tempo, torna a União devedora e credora de montantes simétricos - está a incapacidade de o Tesouro Nacional promover, na magnitude desejada, o aumento de capital da maneira tradicional, isto é, em moeda corrente e com trânsito pelo Orçamento Geral da União. Além da crítica relacionada à falta de transparência, a prática tem reflexos também sobre a credibilidade do cálculo do resultado fiscal, pois traduz um dos artifícios que passaram a ser rotulados por "contabilidade criativa" na apuração do superávit determinado em lei: a despesa primária que seria realizada com o aporte de capital deixa de ocorrer e, ainda assim, o controlador obtém o resultado desejado agora sem macular a meta fiscal.

Ainda relacionado ao resultado fiscal, outro aspecto problemático deriva da retenção, em carteira dos títulos recebidos da União, promovida pelas instituições beneficiárias do empréstimo. É que, dado o diferencial de juros favorável ao devedor - os bancos, no caso -, colhe-se um resultado financeiro positivo ao final do exercício que é repassado, então, ao ente controlador, sob a forma de dividendos (receita primária). Assim, a União alcançaria a melhoria de seu resultado fiscal apenas mediante a emissão de títulos públicos em favor de instituições financeiras controladas, sem que essas necessitem, sequer, após a conversão em moeda, aplicar os recursos na operacionalização das políticas públicas de que tomam parte (ROARELLI et al, 2013). 
Questão também digna de nota é o vulto dos subsídios decorrentes de tais operações, com a consequente carga que impõem sobre as contas públicas. Tanto os custos explícitos aqueles individualizados na Lei Orçamentária Anual (LOA) -, consubstanciados na equalização das taxas de juros devida às instituições financeiras operadoras de financiamentos, quanto os implícitos - que recebem esta denominação justamente por não serem apresentados na LOA de maneira clara -, derivados do diferencial entre o custo de captação da União e o patamar de juros pactuado com os bancos em cada operação de crédito, alcançaram valores não desprezíveis nos últimos anos. O Tribunal de Contas da União (BRASIL, 2012) estimou, ainda no ano de 2012, em R\$28,7 bilhões e R\$ 86,5 bilhões, respectivamente, os montantes correspondentes aos custos explícito e implícito da política, considerando apenas o BNDES e tendo como parâmetro uma soma de R 234,8 bilhões de créditos da União junto à referida instituição - menos da metade, portanto, do valor atualmente verificado nos balanços dos envolvidos.

Problemas adicionais poderiam ser indicados. Contudo, para manter concisa a exposição, encerra-se a presente digressão para retomar o detalhamento das medidas que conformaram a Nova Matriz Macroeconômica.

Além das iniciativas já referidas anteriormente, outras são apontadas no arcabouço da nova política econômica. Oreiro $(2015$, p. 2) indica o "aumento da intervenção do Estado na economia na forma de controle dos preços administrados (combustíveis e tarifas de transporte urbano)" e o "aumento do protecionismo comercial, por intermédio da adoção generalizada da cláusula de 'conteúdo nacional mínimo' nos contratos de fornecimento para o governo e empresas estatais como a Petrobras" (2015, p. 2) (grifos no original). Castro et al (2013, p. 10) referem-se, ainda, a "medidas conjunturais [que] objetivam dar aos setores mais afetados pela crise da indústria uma capacidade de defesa ou de reação diante da concorrência do produto importado, (...) [minimizando] o impacto da concorrência externa na produção doméstica". A esse respeito, promoveu-se a elevação temporária do imposto de importação de cem itens produzidos no Brasil, dos setores de siderurgia, petroquímica, borracha, pneus, medicamentos e bens de capital - Resolução 70/2012, do Conselho de Ministros da Câmara de Comércio Exterior (BRASIL, 2012b).

Intensificou-se, ademais, o ativismo do Banco Central quanto aos controles de capitais e às regulações do mercado cambial:

[em 2011, a autoridade monetária determinou] o recolhimento, sob a forma de depósito compulsório, de $60 \%$ do valor da posição de câmbio vendida [excedente a US\$ 3 bilhões] (...), e instituiu a cobrança de IOF de $1 \%$ sobre os contratos de derivativos cujo valor nocional tenha sido ajustado pela taxa de câmbio e que resultem do aumento da exposição 
líquida vendida. Para reduzir a entrada de capitais, instituiu a cobrança de IOF de $6 \%$ sobre ingresso de recursos no país decorrentes de empréstimo externo com prazo até 360 dias, depois ampliado para 720 dias. (...)

Nos primeiros meses de 2012, o Banco Central deu prosseguimento às políticas que tinham por objetivo reduzir a exposição cambial dos agentes, aumentar o nível de reservas e evitar a entrada de capitais. A cobrança de $6 \%$ de IOF foi alterada para empréstimos externos com prazo de até três anos e, em seguida, para empréstimos de até cinco anos (...) (BASTOS e FONTES, 2014, p. 61-62).

Para os autores, dado que não houve crise internacional aguda ou fortes flutuações na taxa de câmbio no período, o ativismo observado "denota o grau de preocupação do governo com os efeitos da valorização cambial sobre a economia" (BASTOS E FONTES, 2014, p. 65).

Bresser-Pereira (2013, p. 15) confirma essa percepção:

Sem dúvida, a principal explicação para os resultados medíocres do governo Dilma em termos de crescimento do PIB $(2,7 \%$ em 2011 e $0,9 \%$ em 2012) é essa sobreapreciação cambial.

Para compensar essa sobreapreciação o governo adotou uma política fiscal de expansão moderada da despesa pública, e uma política industrial de redução da carga tributária através, principalmente, da desoneração da folha de diversos setores da indústria manufatureira (grifamos).

Diante desse conjunto de alterações implementadas pelo governo da presidente Dilma Roussef, Gonçalves (2015, p. 2) avalia o quadro e opina: “Em 2012 (...) foi aplicado o golpe de misericórdia sobre os três pilares do framework macroeconômico até então existente (consolidação fiscal, metas para inflação e câmbio flutuante)" (tradução livre). O autor assim resume as modificações albergadas pelo novo arcabouço, rotulado de Nova Matriz Macroeconômica: "o crédito público cresceu rapidamente, aumentaram as intervenções visando depreciar a moeda local, e uma política fiscal mais expansiva foi perseguida (...) ao lado de uma política monetária indevidamente frouxa" (GONÇALVES, 2015, p. 2-3) (tradução livre).

Mello (2015, p. 21) assevera que a tentativa de flexibilizar o tripé macroeconômico "na realidade não possuía um conjunto claro de políticas e uma estratégia conjunta”. Nassif (2015, p. 15), de seu lado, é ainda mais incisivo: “[a] nova matriz econômica não passou de um emaranhado de contradições".

Dado que o crédito está entre "as condicionantes mais importantes para o desempenho do consumo" (CALDAS, 2011, p. 442), entre tais contradições estaria - argumenta-se justamente a política expansionista do crédito doméstico "respeitado o regime de metas de inflação" (HOLLAND, 2012), especialmente em um cenário em que os gestores da política econômica estavam determinados a "avançar definitivamente na queda dos juros" 
(MANTEGA, 2012, p. 1-2). Referida incoerência está na origem motivadora do presente trabalho.

Com efeito, segundo Fraga Neto (2009, p. 33):

a participação do Estado no mercado de crédito terá de ser acompanhada de perto. Num momento de crise como o atual, é natural que o BNDES aumente sua participação no financiamento do investimento; mas não se pode esquecer que, mesmo neste caso, um aumento da oferta de crédito reduz o espaço para a queda da taxa de juros (na medida em que reduz a potência da política monetária). Da mesma forma, uma vez superada a etapa crítica do ciclo, caberá cautela para que os mecanismos de crédito oficial não exijam um aperto monetário superior ao que seria a princípio necessário (além de inibir o desenvolvimento de um mercado privado de financiamento de longo prazo) (grifamos).

Tais assertivas são especialmente relevantes diante da constatação de que "o canal de crédito - a relação crédito/PIB cresceu significativamente desde 2005 - tem recentemente se tornado um elemento importante no ciclo econômico do país" (MINELLA e SOUZASOBRINHO, 2011, p. 87). O canal de crédito será objeto do próximo capítulo. 


\section{CANAL DO CRÉDITO}

Neste capítulo será exposta a abordagem teórica atinente ao canal do crédito: sua origem, fundamentos e peculiaridades, conceituando e diferenciando as vertentes do balance sheet channel e do banking lending channel. Serão apresentadas, ainda, evidências empíricas colhidas na literatura nacional e na internacional acerca da existência e do funcionamento do canal do crédito e da influência dos movimentos desse agregado sobre a economia real. Por fim, far-se-ão breves comentários sobre a importância do crédito em um contexto de restrição de liquidez imposta a firmas e famílias.

\subsection{Teoria do canal do crédito}

Historicamente, "uma substancial quantidade de recursos tem sido dedicada ao estudo do relacionamento entre moeda e produto" (CALZA e SOUZA, 2005, p. 5). Bernanke e Blinder (1992, p. 901) asseveram que os efeitos e os mecanismos de transmissão da política monetária são dois dos temas mais importantes no estudo da macroeconomia. Mishkin (1995, p. 3), por seu turno, aponta que a política monetária tem assumido, cada vez mais, uma posição central na gestão macroeconômica, aduzindo que “o entendimento dos mecanismos de transmissão monetária é crucial para responder uma ampla gama de questões na formulação de políticas" (p. 9).

Não obstante referidas constatações, o período entre o final da década de 1980 e o início dos anos 1990 do século passado era marcado por um ambiente no qual havia amplo consenso acerca da influência da política monetária sobre o curso da economia real, mas pouca convergência sobre como exatamente tal influência verificava-se, na prática (BERNANKE e GERTLER, 1995, p. 3). Nesse cenário, iniciou-se o desenvolvimento da teoria do canal do crédito, que pretendeu preencher certas lacunas na análise dos mecanismos de transmissão e da magnitude dos efeitos reais decorrentes da política monetária.

Bernanke (1992) explica que, além da tradicional visão de que a autoridade monetária pode reduzir a demanda agregada mediante drenagem de reservas do sistema bancário diminuindo a disponibilidade de moeda, o que, via de consequência, eleva os juros no curto prazo e, ao fim, deprime a demanda pelo aumento dos custos relativamente ao retorno do capital (FRIEDMAN, 1968, apresenta argumento similar) - deve-se ter em conta, também, o canal de transmissão da política monetária através do crédito: o impacto de referida política é 
potencializado pela alteração nos termos ou na própria disponibilidade de novos empréstimos bancários.

No primeiro caso - visão tradicional - tem-se em operação o canal dos juros, por meio do qual mudanças na taxa real de juros de curto prazo influenciam o custo do capital e, por conseguinte, afetam o investimento das empresas e a demanda pelo consumo de bens por parte das famílias, alterando o próprio nível de produção da economia (BLACK e ROSEN, 2011, p. 4).

Esquematicamente:

$$
\downarrow \mathrm{M} \rightarrow \uparrow \mathrm{i} \rightarrow \uparrow \mathrm{r} \rightarrow \downarrow \mathrm{I} \rightarrow \downarrow \mathrm{Y}, \quad \text { isto é: }
$$

uma política monetária contracionista reduz a liquidez da economia $(\mathrm{M} \downarrow)$, elevando a taxa nominal de juros (i $\uparrow$ ), o que, por sua vez, implica aumento do juro real ( $\mathrm{r} \uparrow$ ), supondo dada a taxa de inflação no curto prazo. A elevação da taxa real de juros eventualmente aumenta o custo do capital, o que acaba deprimindo o nível de investimento (I $\downarrow$ ) e, consequentemente, a demanda agregada (Y $\downarrow$ ) (SOUZA-SOBRINHO, 2003, p. 11).

O mecanismo convencional acima descrito deriva de um modelo keynesiano que "agrupa empréstimos bancários junto a outros instrumentos de dívida em um 'mercado de títulos', que é, então, convenientemente suprimido pela Lei de Walras" (BERNANKE e BLINDER, 1988, p. 435).

A visão do canal do crédito rejeita referida assunção de perfeita substituição entre títulos e empréstimos bancários. Com base na hipótese de informação imperfeita nos mercados financeiros, é atribuído ao canal do crédito o potencial de amplificar os efeitos previstos pela visão tradicional, por meio das modificações no custo dos financiamentos que decorrem dos movimentos na taxa básica de juros da economia; desse modo, a teoria do canal do crédito não se coloca como um mecanismo independente e paralelo de transmissão da política monetária (BERNANKE e GERTLER, 1995).

Walsh (2010, p. 478) sintetiza as principais particularidades que diferenciam as visões referidas acima:

A visão do crédito ressalta o papel distinto desempenhado por ativos e passivos financeiros. Em vez de agregar todos os ativos financeiros não monetários em uma única categoria chamada de títulos, a visão do crédito argumenta que os modelos macroeconômicos precisam distinguir entre os diferentes ativos não monetários, seja diferenciando entre fontes de recursos bancárias e não bancárias ou, de maneira geral, entre financiamento externo e interno. A visão do crédito também destaca a heterogeneidade entre devedores, sublinhando que alguns deles podem ser mais vulneráveis que outros a mudanças nas condições de crédito. Finalmente, o investimento pode ser sensível a variáveis tais como patrimônio líquido ou fluxo de caixa se os custos de agenciamento associados à informação imperfeita ou monitoramento criarem uma cunha entre o custo de fundos internos e externos. Um aumento na taxa de juros pode provocar uma contração mais forte sobre a economia se a posição financeira das empresas 
já estiver fraca, introduzindo a possibilidade de não-linearidades nos impactos da política monetária (tradução livre, grifamos).

Embora concebida sob um modelo IS-LM tradicional, a teoria do canal do crédito é aceita por correntes não keynesianas (FUERST, 1992). Para Bernanke e Gertler (1995, p. 910), o desenvolvimento da teoria em questão foi motivado pela observação de alguns puzzles não explicados, adequadamente, pela via única do efeito dos juros sobre o custo de capital. Tais enigmas estariam relacionados à magnitude, ao timing e à composição da resposta da economia aos choques de política monetária:

i) mesmo pequenas inovações na taxa de juros de mercado afetam consideravelmente a economia real, embora não se observem movimentos de mesma magnitude nos componentes do gasto privado, quando considerados unicamente os efeitos devidos ao custo de capital;

ii) há um descasamento entre o timing do movimento nos juros e a resposta dos componentes de gasto privados; enquanto um choque na taxa básica é largamente transitório (com os juros retornando à sua tendência em cerca de nove meses após a perturbação), alguns agregados reais somente começam a responder com considerável atraso e a duração do choque prolonga-se no tempo;

iii) a resposta da economia não é a esperada em termos de composição dos efeitos do choque monetário, pois variáveis que deveriam depender dos juros de longo prazo, como investimentos em habitação, acabam por reagir mais rápida e fortemente à inovação nos juros de curto prazo, comparativamente a estoques e consumo de alguns tipos de bens duráveis.

Os defensores da visão do crédito argumentam, então, que "a política monetária afeta não apenas o nível geral de juros, mas também o tamanho do prêmio de financiamento externo" (BERNANKE e GERTLER, 1995, p. 11), definido como "a diferença no custo entre fundos levantados externamente (via emissão de ações ou de dívida) e fundos gerados internamente (pela retenção de lucros)" (BERNANKE e GERTLER, 1995, p. 5). Esse movimento complementar observado no prêmio de financiamento externo, prosseguem os autores, "pode ajudar a melhor explicar a força, o timing e a composição dos efeitos da política monetária” (BERNANKE e GERTLER, 1995, p. 11).

Nesse quadro conceitual, o canal do crédito tem suas bases na ideia de informação imperfeita, primariamente apontada por Akerlof (1970), em contraposição ao modelo de mercados completos. Sob esse paradigma, o papel intermediador dos bancos - criadores de moeda escritural por intermédio da multiplicação do crédito - ganha relevo por reduzir a assimetria de informação entre poupadores e tomadores de recursos. Ainda antes de se terem 
claros os contornos da economia da informação, Modigliani (1965) afirmou que, diante do papel dos intermediadores financeiros e das falhas de mercado, a política monetária deveria passar a ser entendida como o controle sobre o poder dos bancos de criar moeda, tamanho o poder e influência de tais instituições sobre os efeitos da referida política.

Comumente, são pontuados dois ramos através dos quais se dá o funcionamento da visão do crédito: o canal dos empréstimos bancários (bank lending channel) e o canal do balanço dos devedores (balance sheet channel). Enquanto o primeiro está voltado aos efeitos da política monetária sobre o lado da oferta do crédito intermediado, o segundo dedica-se a avaliar tais impactos sobre o lado dos demandantes (BERNANKE e GERTLER, 1995).

Bernanke e Blinder (1988) sugerem que o bank lending channel materializa o efeito transmitido por intermédio do nível e composição dos ativos bancários. No caso:

uma "política monetária contracionista $[\mathrm{M} \downarrow$, mediante venda de títulos no mercado pelo Banco Central, aumento da alíquota dos depósitos compulsórios ou da taxa de redesconto, por exemplo] drena reservas do sistema bancário [R $\uparrow$, deixando os bancos com menos recursos disponíveis para tomada [e, portanto, concessão] de empréstimos (DL $\downarrow$, depósitos livres), reduzindo o crédito [L $\downarrow$ ]" (BLACK e ROSEN, 2011, p. 4) (tradução livre).

Ou seja:

$\downarrow \mathrm{M} \rightarrow \uparrow \mathrm{R} \rightarrow \downarrow \mathrm{DL} \rightarrow \downarrow \mathrm{L}$.

Ainda que não se observe uma redução relevante na quantidade de fundos disponíveis aos bancos, a elevação nos custos de intermediação em épocas de aperto monetário acarretaria uma redução no volume de empréstimos (Black e Rosen, 2011, p. 4).

Conforme argumentam Bernanke e Gertler (1995, p. 18), bancos são a fonte primordial de crédito intermediado na maioria dos países e, portanto, "uma redução na oferta de crédito bancário, em relação a outras formas de crédito, provavelmente aumenta o prêmio de financiamento externo e reduz a atividade real" (tradução livre), fechando o ciclo de transmissão da política monetária via canal dos empréstimos bancários $(\downarrow \mathrm{L} \rightarrow \downarrow(\mathrm{I}+$ Consumo) $\rightarrow \downarrow Y$ ).

Nesses termos, é apropriada a conceituação oferecida por Brooks (2007, p. 3), que resume o até aqui dito:

O bank lending (ou narrow credit) channel refere-se ao efeito adverso de maiores taxas de juros sobre a oferta de crédito bancário, que pode reprimir a atividade econômica se firmas e consumidores não conseguirem substituir completamente os empréstimos em falta por outras fontes de crédito (tradução livre).

Blinder e Stiglitz (1983) corroboram o argumento e acrescentam que a recessão decorrente do aperto monetário pode ser verificada ainda que a elevação na taxa de juros seja de pequena monta, de modo que a efetividade da atuação do Banco Central não dependeria de uma alta elasticidade em relação aos juros. 
O balance sheet (ou broad credit) channel, por sua vez, parte da premissa de que assimetrias de informação acarretam um custo de crédito (prêmio de financiamento externo) pago pelo tomador que é inversamente proporcional à força de sua posição financeira, medida em termos de patrimônio líquido, endividamento, liquidez e fluxo de caixa (BERNANKE e GERTLER, 1989). O canal do balanço refletiria, justamente, o impacto da política monetária sobre a posição financeira dos tomadores de crédito (com seus respectivos custos de endividamento): "ao induzir um declínio na atividade real e na inflação, um aperto monetário deteriora o fluxo de caixa dos tomadores de crédito e aumenta o custo de suas dívidas, elevando o prêmio de financiamento externo [pfe $\uparrow$ ]" (HENDRICKS e KEMPA, 2011, p. 404) (tradução livre).

Bernanke e Gertler afirmam que uma mudança na política monetária altera a posição financeira dos tomadores de crédito tanto direta quanto indiretamente. De maneira direta, por exemplo:

um aperto monetário $[\mathrm{M} \downarrow]$ enfraquece os balanços dos devedores de pelo menos duas formas: primeiro, na extensão em que têm dívidas de curto prazo ou com juros flutuantes, um aumento na taxa de juros diretamente aumenta suas despesas financeiras, reduzindo o fluxo de caixa líquido e enfraquecendo a posição financeira dos tomadores de crédito $[P F \downarrow]$. (...) Segundo, o aumento na taxa de juros também está tipicamente associado ao declínio no preço dos ativos, o que, entre outras coisas, diminui o valor das garantias dos devedores (1995, p. 13) (tradução livre).

Indiretamente, uma contração monetária pode reduzir a demanda pelos produtos da firma - e, consequentemente, suas receitas - enquanto os custos permaneceriam estáveis no curto prazo; isso aumentaria a necessidade de financiamento da firma, erodindo seu patrimônio e solvência ao longo do tempo (BERNANKE e GERTLER, 1995, p. 13).

Desse modo, sintetizam os autores:

como a posição financeira dos tomadores de crédito afeta o prêmio de financiamento externo e, assim, os termos gerais do crédito à sua disposição [L], flutuações na qualidade dos balanços dos tomadores deveria, similarmente, afetar suas decisões de investimento [I] e de gastos (BERNANKE e GERTLER, 1995, p. 12) (tradução livre).

O esquema a seguir resume a mecânica do balance sheet channel:

$\downarrow \mathrm{M} \rightarrow \downarrow \mathrm{PF} \rightarrow \uparrow \mathrm{pfe} \rightarrow \downarrow \mathrm{L} \rightarrow \downarrow \mathrm{I} \rightarrow \downarrow \mathrm{Y}$.

Black e Rosen (2011, p. 4-5) lembram, também, que os emprestadores podem reduzir a concessão de crédito a firmas que experimentam um aumento em seus respectivos prêmios de financiamento externo, escolhendo, alternativamente, realizar aplicações em investimentos mais seguros (flight to quality). Destarte, os efeitos do broad credit channel seriam mais intensos sobre pequenas empresas com posições financeiras mais frágeis, implicando uma realocação na oferta de crédito entre firmas na economia - das menores para as maiores (BLACK e ROSEN, 2007, p.1). 
Naturalmente, o canal do crédito funciona nos dois sentidos. Bernanke (1992) exemplifica: uma flexibilização na política monetária, reduzindo os juros de mercado, acarreta uma melhoria da liquidez das firmas (ao suavizar a relação juros/fluxo de caixa) e pode levar a um aumento de gastos no setor, caso essa melhoria de liquidez reflita-se em maior disponibilidade interna de fundos e/ou aumente a capacidade das firmas em atrair financiamentos externos.

Mishkin (2010, p. 608) registra, ainda, que "embora a maioria da literatura sobre o canal do crédito dedique-se ao gasto empresarial, a visão do crédito deve-se aplicar igualmente às despesas de consumo das famílias, particularmente com bens duráveis e habitação." (tradução livre):

O declínio na concessão de empréstimos bancários induzido por uma contração monetária deveria causar uma queda na aquisição de bens duráveis e de imóveis por parte de consumidores que não têm acesso a outras fontes de crédito. Similarmente, aumentos na taxa de juros causam uma deterioração no balanço das famílias, pois o fluxo de caixa dos consumidores é negativamente afetado (MISHKIN, 2010, p. 608) (tradução livre).

Desse modo, existiria um "efeito liquidez sobre as famílias", em decorrência política monetária, cujo funcionamento dar-se-ia da seguinte forma: uma expansão monetária $(\mathrm{M} \uparrow)$ aumenta o preço das ações e dos ativos financeiros em poder das famílias (AF $\uparrow$ ); dada a relação inversa entre a solidez do seu patrimônio e a probabilidade de que determinada família passe por uma crise financeira, o reforço da posição financeira da família reduziria essa probabilidade $(\mathrm{O} \downarrow)$ e estimularia o consumo de bens duráveis e a aquisição de imóveis $(\mathrm{D} \uparrow)$, com reflexos sobre o produto agregado (Y $\uparrow)$. Em notação:

$$
\uparrow \mathrm{M} \rightarrow \uparrow \mathrm{AF} \rightarrow \downarrow \mathrm{O} \rightarrow \uparrow \mathrm{D} \rightarrow \uparrow \mathrm{Y} \quad \text { (MISHKIN, 2010, p. 608-609) }
$$

O autor aponta, por fim, três razões que atestam a importância do canal do crédito entre os mecanismos de transmissão da política monetária:

i) o considerável corpo de evidências sobre o comportamento das firmas que convalida a relevância de imperfeições no mercado de crédito para decisões de gasto e de quantitativo de pessoal por parte das firmas;

ii) a evidência de que firmas menores (e mais prováveis a sofrer restrições de liquidez) são mais afetadas por contrações monetárias, comparativamente a grandes corporações;

iii) a construção teórica sobre o canal do crédito, fortemente calcada na assimetria de informações, tem ajudado a explicar outros importantes fenômenos, tais como as razões para a estrutura e própria existência do sistema financeiro, e os motivos pelos quais crises no setor são tão prejudiciais à economia (MISHKIN, 2010, p. 609). 


\subsection{Evidências empíricas}

No que diz respeito a estudos empíricos, inúmeros trabalhos dedicaram-se a demonstrar a existência do canal do crédito e seus respectivos efeitos sobre variáveis econômicas relevantes. Kashyap e Stein (1994, p. 247) enumeram vários papers que, fazendo uso de dados agregados ou individualizados em nível de firmas, sugerem que "a transmissão monetária opera, pelo menos parcialmente, através de mudanças induzidas na oferta de empréstimos". Referidos autores conduziram, posteriormente, pesquisa que investigou os efeitos de uma política monetária restritiva sobre a atividade bancária, concluindo que as instituições financeiras com menor liquidez reduzem mais fortemente seus empréstimos em tais circunstâncias - observou-se um gap de 5,3\% no nível de empréstimos entre bancos líquidos e ilíquidos, após um ano do choque positivo na taxa básica de juros, achado favorável à existência do bank lending channel (KASHYAP e STEIN, 2000).

Oliner e Rudebusch (1996), empregando dados de mais de 7.000 empresas manufatureiras norte-americanas, concluem que, após uma contração monetária, firmas de pequeno porte tornam-se mais dependentes de fundos gerados internamente, indicando escassez de financiamento externo - tal como prevê o mecanismo descrito pelo balance sheet channel. No mesmo sentido, Gilchrist e Zakrajsek (1995) apontam a alta responsividade de pequenos negócios às condições gerais de crédito prevalentes: pós-aperto monetário, a contração observada em manufaturas é 2,5 maior que a experimentada por grandes empresas.

Ciccarelli et al (2010) utilizam-se de um modelo de vetores autorregressivos (VAR) com dados da zona do Euro e dos Estados Unidos e apresentam evidências do funcionamento do canal do crédito em tais regiões, tanto pela via do balanço dos devedores quanto pelo canal dos empréstimos bancários, abrangendo crédito imobiliário, a empresas e aos consumidores. Os autores acrescentam que o bank lending channel impacta mais fortemente as firmas, enquanto as famílias sofrem com mais intensidade os efeitos repassados através do balance sheet channel. Tornell e Westermann (2002) atestam a existência do canal do crédito em países de renda média (entre os quais o Brasil) e afirmam que referido mecanismo representa um forte componente na transmissão da política monetária em tais nações.

Evidências sobre o canal do crédito também são encontradas na literatura nacional. Oliveira e Andrade Neto (2008) avaliam que "o fato de [o Brasil] não apresentar um mercado de capitais desenvolvido indica que os empréstimos bancários são de grande relevância como fonte de financiamento nesse país". Com base em referida hipótese, os autores conduzem investigação objetivando verificar a existência e relevância do canal de empréstimos 
bancários no Brasil, com base em balancetes mensais colhidos de 293 instituições financeiras entre 1994 e 2005. Os resultados apresentados pelo artigo corroboram a existência de um canal de empréstimos bancários ativo na transmissão da política monetária brasileira.

No mesmo sentido, Souza-Sobrinho (2003) apresenta evidências empíricas para o bank lending channel no Brasil, durante o período pós-Plano Real. O estudo empreendido conclui que "a oferta de crédito e, em menor grau, o spread bancário contêm informação que ajuda a prever o comportamento futuro do produto", reforçando a importância do canal dos empréstimos bancários (SOUZA-SOBRINHO, 2003, p. 9). O autor registra, ademais, que, "Apesar da baixa relação crédito/PIB, os dados sobre a estrutura de financiamento comprovam a existência de firmas dependentes dos bancos no Brasil, que é uma das condições necessárias para a operação do canal do crédito" (SOUZA-SOBRINHO, 2003, p. 30).

Carneiro et al (2006, p. 20) examinam "o canal de crédito como transmissor dos choques de demanda, via balanço das empresas, atuando como um "multiplicador financeiro" e apresentam evidências acerca da presença desse mecanismo de propagação da política monetária na economia brasileira.

A literatura acima referida, portanto, confirmou, no cenário nacional e internacional, a existência do canal do crédito, bem como seus efeitos sobre a operação da política monetária.

Nesse contexto, o processo de criação de crédito - consubstanciado no direcionamento da poupança de determinadas firmas e indivíduos para o uso de outras firmas e indivíduos (seja para investimento ou consumo) (BERNANKE, 1992) - e a atividade bancária - cuja própria existência é baseada no conceito de suprimento de liquidez (BARBI, 2014a) passaram a gozar de papel proeminente no novel arcabouço teórico voltado à revelação dos efeitos da política monetária sobre a atividade econômica, atraindo a atenção da pesquisa macroeconômica recente. A esse respeito, mencionam-se, a seguir, estudos dedicados a investigar o impacto do volume de empréstimos sobre preços e atividade real.

A forte correlação entre empréstimos e produção vem de longa data (WALSH e WILCOX, 1995). De fato, conforme lembram Avdjiev e Zeng (2014, p. 2) "a noção de que evoluções no mercado de crédito afetam flutuações cíclicas na atividade macroeconômica pode ser resgatada desde Fisher (1933) e Keynes (1936)" (tradução livre). Friedman e Kuttner (1993, p. 210), por exemplo, observam que "tanto preços quanto quantidades no mercado de crédito de curto prazo contêm informação estatisticamente significante acerca das flutuações subsequentes no produto real": um choque no volume de empréstimos tem efeito expansionista sobre a produção. Avdjiev e Zeng (2014) confirmam o resultado para os 
Estados Unidos, enquanto Calza e Souza (2005) e Ozcelebi (2012) oferecem conclusões análogas para a zona do Euro e Turquia.

Gilchrist e Zakrajsek (1995) apresentam robustas evidências no sentido de que o fluxo de crédito possui poder preditivo em relação à atividade econômica: um aumento no endividamento das firmas leva a um acréscimo altamente significante nas taxas de crescimento do PIB, da produção e do emprego da indústria manufatureira.

Naturalmente, diante da constatação acerca da influência do crédito sobre o produto, aliada ao efeito expansivo que um aumento na oferta de empréstimos acarreta sobre a quantidade de moeda no mercado (BERNANKE e BLINDER, 1988), vários estudos buscam associar os movimentos no mercado de crédito com a inflação observada em determinada economia, quantificando os impactos decorrentes de tal relação.

Moinescu (2012, p. 2) explicita o argumento: “o crescimento do consumo doméstico acima da capacidade interna de produção, por intermédio de empréstimos bancários, alimenta a formação de uma espiral de preços, mascarada por um processo de pseudo-convergência". Dessa forma, "a aceleração no crédito induz um crescimento superior ao produto potencial e a economia entra em um processo de sobreaquecimento, que favorece o aumento generalizado dos preços" (MOINESCU, 2012, p. 3). O autor conduz estudo econométrico voltado à zona do Euro, concluindo que um choque no fluxo de crédito reflete-se em um desvio de $15 \%$ do crescimento econômico em relação ao nível potencial; mencionado o hiato do produto, por seu turno, eleva em $15 \%$ a média de inflação observada. A pesquisa destaca, ainda, que

Nem mesmo um cenário de desaceleração da economia está livre de riscos à estabilidade dos preços, dado que a redução das receitas devido a um hiato negativo do produto não é acompanhada por um ajuste similar nas despesas. Em tal contexto, há forte pressão sobre o déficit governamental e a taxa de inflação pode registrar crescimento significativo, impulsionada pelo inevitável aumento de impostos (MOINESCU, 2012, p. 9) (tradução livre).

Ainda mais didática é a explicação oferecida por Avdjiev e Zeng (2014, p. 13):

Intuitivamente, um choque positivo no volume de crédito é mais efetivo no estimulo à demanda agregada quando a economia está operando abaixo de sua plena capacidade (...) que quando está sobreaquecida. No primeiro caso, a demanda adicional desencadeada pelo impulso do crédito pode ser acomodada empregando-se os recursos ociosos da economia. Em contraste, no último caso há poucos recursos ociosos a serem utilizados e a demanda adicional criada pela expansão no volume de crédito leva a uma maior inflação em vez de um maior crescimento do produto (tradução livre, grifamos).

Calza e Souza (2005) lançaram mão de um sistema não linear de vetores autorregressivos para investigar a resposta da inflação a choques creditícios. Os autores mostram que um choque real na taxa de crescimento de crédito é seguido por um desvio positivo e estatisticamente significante da inflação, no curto prazo. 
Korkmaz (2015) cita, ainda, os seguintes estudos acerca do crédito e seus impactos na evolução do nível de preços: Tang (2001) confirmou a existência de um equilíbrio de longo prazo na Malásia entre inflação e oferta monetária, crédito bancário, renda real e preço dos produtos importados; Eslamloueyan e Darvishi (2007) apontaram que existe um relacionamento de longo prazo entre inflação e seus principais determinantes no Irã: crédito bancário, PIB, taxa de câmbio e preço dos produtos importados; Arsène e Guy-Paulin (2013) buscaram esclarecer as relações existentes entre o crédito ao setor privado, a inflação e o crescimento econômico, concluindo que o crédito insuficiente retarda o crescimento e, noutro sentido, quando em excesso traz consigo o problema da hiperinflação.

No que concerne ao Brasil, Catão e Pagan (2009) registram que choques creditícios têm efeitos não triviais sobre o produto interno e a inflação no Brasil e no Chile. Além disso, os autores indicam a existência de um eventual efeito moderador que o canal do crédito poderia apresentar em relação a choques monetários sobre consumo e investimento nacionais, por meio dos efeitos transmitidos via taxa de câmbio:

enquanto maiores taxas de juros reduzem a absorção interna através do efeito intertemporal padrão, também alimentam a demanda por crédito bancário mediante a apreciação do câmbio no curto prazo que uma contração monetária tipicamente acarreta. Os efeitos balanço e/ou riqueza que derivam da apreciação da moeda (particularmente para produtores de bens não comercializáveis, que tendem a ser mais dependentes do crédito bancário) mitigam o impacto contracionista padrão que um aperto monetário exerce sobre a absorção interna. Muito embora o efeito recessivo seja maior, no agregado, aparentemente tal efeito é mitigado pelo impacto intratemporal provocado pelo câmbio (CATÃO e PAGAN, 2009, p. 35).

Saxegaard (2006) também analisa a execução da política monetária em um ambiente de expansão creditícia. $\mathrm{O}$ autor pontua os riscos inflacionários inerentes a uma expansão no crédito e anota que os bancos centrais devem examinar a eventual necessidade de remover o excesso de liquidez do sistema, evitando a materialização do mencionado risco de uma escalada nos preços. Os Bancos Centrais do Brasil (1999) e da Europa (2005) já demonstraram estar atentos ao tema. A esse respeito, Barbi (2014b, p. 68) registra que, nas minutas do Comitê de Política Monetária (Copom), o Banco Central do Brasil "tem repetidamente argumentado em desfavor do crédito público, insistindo na redução dessa forma de estímulo fiscal".

A evidência empírica aqui descrita denota, em nível agregado, a importância dos movimentos relacionados às variáveis creditícias para a gestão macroeconômica. No caso brasileiro, por exemplo, viu-se que o canal do crédito é relevante e pode interferir na transmissão dos impactos desejados pela autoridade monetária quando esta induz 
perturbações na taxa básica de juros. Ademais, a associação entre o avanço no volume do crédito e a inflação, conforme acima apontado, constitui o próprio cerne desta pesquisa.

É de se ressaltar, por outro lado, que os dados em nível agregado refletem, naturalmente, decisões tomadas individualmente por firmas e famílias. Nesse sentido, relevante parcela da literatura econômica - de cunho teórico e prático - aborda o tema, destacando o papel do crédito como um fator relevante para a conformação dos níveis de consumo, poupança e investimento dos indivíduos. Naturalmente, é clara a relação existente entre os efeitos do funcionamento canal do crédito e o consequente recrudescimento (ou relaxamento) das restrições de liquidez de firmas e famílias - e vice-versa - pelo que se mostra oportuno oferecer breves comentários sobre o assunto. A próxima seção trata do tema na extensão requerida.

\subsection{Liquidez e demanda de firmas e famílias: teoria e evidências empíricas}

Do ponto de vista das famílias, a decisão pelo endividamento pode caracterizar uma escolha ótima, por levar a um aumento do bem-estar ao proporcionar um padrão mais desejável de gastos e possibilitar a suavização da trajetória do consumo ao longo do tempo (BERTOLA et al, 2006). Em síntese, para alcançar essa conclusão, tais autores partem do modelo de comportamento do consumidor baseado na hipótese da renda permanente e sumarizado como se segue (DEATON, 1992): as famílias escolhem seu nível de consumo, em cada período, sujeitas a uma restrição orçamentária. O problema da família é, então, maximizar seu nível de utilidade, dada a restrição intertemporal em comento. $\mathrm{O}$ crescimento do consumo depende da magnitude relativa entre a taxa de juros e uma taxa de desconto subjetiva, particular à família, sendo a relação entre as utilidades marginais do consumo atual e futuro dado pela equação de Euler (ROMER, 2012). A mecânica do modelo estende-se a decisões de consumo relativas a bens duráveis, ainda que tais bens representem, ao mesmo tempo, a alocação de recursos em consumo e uma parte da riqueza da família.

Nesse framework:

Quando se espera que o valor presente da renda cresça, é ótimo que a poupança seja negativa: a família irá reduzir seus ativos, ou endividar-se caso não possua ativos, se aguarda uma renda futura maior (...). Inversamente, a família irá poupar se prevê uma redução na renda futura (...). Poupança e endividamento tornam possível redistribuir gastos durante o ciclo de vida, de períodos em que a renda é alta para períodos em que a renda é baixa (BERTOLA et al, 2006, p. 5-6, tradução livre).

Destarte, dado que a solução para o problema de otimização do agente pode indicar um nível de gastos superior ou inferior a sua renda corrente, o mercado de crédito permite 
unir unidades deficitárias e superavitárias em benefício mútuo (POOLE, 1993), caracterizando-se como um fator potencialmente relevante para a maximização do bem-estar das famílias. A pesquisa econômica empírica debruçou-se sobre referida hipótese convalidando-a - conforme breve extrato indicado a seguir.

Utilizando dados dos Estados Unidos para o período pós $2^{\mathrm{a}}$ Guerra Mundial, Campbell e Mankiw (1990) examinam a consistência da Hipótese da Renda Permanente (apenas mudanças não previstas na renda afetam o consumo), a partir de estimativas do efeito de alterações previsíveis no nível de renda sobre o consumo. Os resultados indicam que ao menos parte dos consumidores sofre restrição de liquidez e, portanto, fricções no mercado de crédito têm efeito na demanda agregada.

Zeldes (1989) examina as implicações de eventuais restrições de crédito para o consumo das famílias norte-americanas e confirma a hipótese de que a incapacidade de endividar-se, antecipando os rendimentos futuros do trabalho, afeta o consumo de significante parcela da população. Ludvigson (1999) aduz que a antecipação de um aumento no crédito ao consumidor está significativamente relacionada ao crescimento no consumo agregado.

Em um estudo sobre o comportamento do consumo em nível agregado abrangendo o Brasil e outros países sulamericanos, Gomes e Paz (2010) concluem que os consumidores brasileiros sofrem restrição de liquidez, reforçando a importância do crédito para o nível de dispêndios das famílias. Na mesma linha, Gomes (2010) encontra evidência em favor da hipótese de restrição de crédito e do comportamento das famílias brasileiras no sentido de suavizar o consumo ao longo do tempo.

Por seu turno, diante da opção de investir em determinado ativo, as firmas decidem racionalmente, amparadas no critério de maximização de valor de mercado (MODIGLIANI e MILLER, 1958). De maneira análoga, a estrutura ótima de capital da firma busca a minimização dos custos de transação, ou seja, uma vez feita a opção pelo investimento, a origem dos recursos (se interna ou externa) baliza-se pelo menor custo de agenciamento (JENSEN e MECKLING, 1976).

Fazzari, Hubbard e Petersen (1988) concluíram que o fluxo de caixa das empresas tem um efeito positivo e significante sobre o investimento, indicando que, também no caso das firmas, a variável crédito é determinante para o nível de dispêndio.

Partindo das evidências acima, no sentido de que a disponibilidade de liquidez é relevante para a decisão de gastos de famílias e firmas, Bayoumi e Melander (2008) apresentam o seguinte modelo para explicitar os relacionamentos entre variáveis macrofinanceiras: 
Figura 3.1: Modelo para relações macrofinanceiras

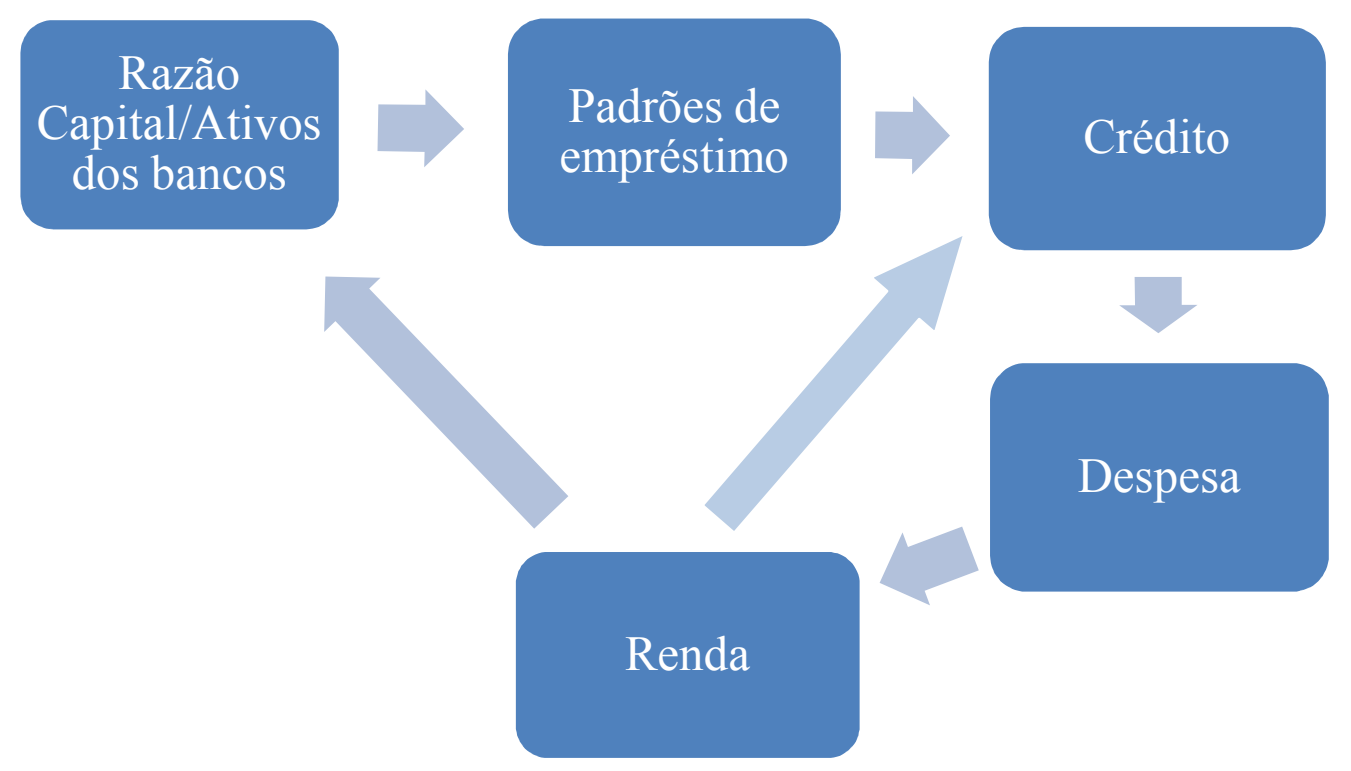

De acordo com o modelo, partindo-se, por exemplo, de um aumento na razão requerida entre capital e ativos das instituições financeiras, quer por razões regulatórias, quer pela disciplina do mercado, serão observadas restrições na capacidade de concessão de crédito por parte das entidades bancárias. Esse movimento induz a adoção de padrões mais rígidos para a liberação de empréstimos, refletindo-se na disponibilidade de crédito. A queda no crédito tem um efeito direto no nível de despesa, em virtude das restrições de liquidez de firmas e famílias. Por seu turno, a mudança no patamar de gastos acarreta alterações na renda agregada via mecanismos multiplicadores. Por fim, a redução na renda reflete negativamente nos balanços de firmas e famílias, potencializando a restrição de crédito e acelerando perdas na atividade de intermediação, o que deteriora ainda mais a razão capital/ativos dos bancos, completando e reiniciando o ciclo.

Em seguimento, os autores estimaram o efeito quantitativo do crédito sobre o gasto agregado. Para os três componentes do gasto (bens de consumo, imóveis e investimento empresarial) constataram-se impactos positivos e significantes: um aumento de um dólar em crédito ao consumidor provoca uma elevação contemporânea no gasto com bens de consumo de 0,64 dólar, e um acréscimo adicional de 0,26 dólar depois de um trimestre; para o crédito imobiliário, a relação, no longo prazo, é de 0,10 dólar gasto em imóveis para cada dólar adicional de crédito concedido; por fim, para um dólar extra de crédito a firmas, o investimento empresarial responde em 0,12 dólar no período, e outro 0,50 dólar no longo prazo. 
Vê-se, portanto, que o endividamento de famílias e empresas apresenta-se como instrumento viabilizador de escolhas ótimas e, de fato, impacta a decisão e o nível de dispêndio. Bernanke e Gertler (1995) anotam que a demanda por crédito contém, aparentemente, forte componente contracíclico, derivado do desejo de firmas e famílias de suavizar as variações em sua renda sobre seus dispêndios com produção ou consumo.

No caso recente do Brasil, a intervenção governamental no mercado de crédito, discutida no Capítulo 2, pode ter acarretado um crescimento do crédito agregado incompatível com a estrutura de produção nacional, gerando instabilidade macroeconômica:

O desequilíbrio de curto prazo entre oferta e demanda, espelhado pela abundância de crédito ao consumo, sugere que se o consumo crescer mais rápido que a oferta de investimentos haverá pressão sobre o nível de preços. (...) O crédito público ao consumo tem crescido mais rápido que o crédito às empresas. De fato, a inflação atual tornou-se estável bem acima da meta de 4,5\%, sugerindo que o crédito público tem alguma responsabilidade sobre a inflação corrente (BARBI, 2014b, p. 68, tradução livre).

De modo semelhante, embora apresentem raízes e diagnóstico diversos para o fenômeno, Belluzzo e Coutinho (1998, p. 139) argumentam que a maior alavancagem dos gastos das famílias excita "a demanda muito além das expectativas normais dos empresários que produzem bens de consumo", causando elevações de preços.

Nesse compasso, utilizando-se da abordagem proposta por Pesaran et al (2001), investiga-se, para o caso brasileiro, a existência de relacionamento, no curto e longo prazos, entre inflação e determinadas variáveis (crédito total entre elas) que seguem processos de diferentes ordens, mediante a adoção de um modelo irrestrito de correção de erros (UECM). A estratégia econométrica lança mão de dados agregados, à semelhança dos estudos empreendidos por Barbi (2014b) e Fonseca (2014) e abarca, ainda, a análise de funções resposta-impulso e da decomposição da variância dos erros de previsão a partir de um modelo vetorial de correção de erros (VECM), conforme detalhado no capítulo seguinte. 


\section{MODELO}

Uma vez exposto o quadro caracterizado pela política econômica nacional nos últimos anos, bem como a apresentação dos fundamentos teóricos pertinentes ao canal do crédito e suas implicações para a economia, o presente capítulo dedica-se, inicialmente, a detalhar o conjunto de dados utilizados com o objetivo de levar a termo a investigação sobre o relacionamento entre crédito e inflação, no curto e longo prazos. A seção 4.2, por seu turno, cuida da descrição da estratégia econométrica e dos modelos adotados (ARDL e VECM), tendo em vista o objetivo que balizou o desenvolvimento desta pesquisa.

\subsection{Dados}

Diversos estudos empíricos na literatura nacional dedicam-se ao propósito de identificar os determinantes da taxa de inflação observada no País. Considerando referida literatura - em parte detalhada adiante - e tendo em conta o cerne da investigação empreendida neste trabalho, assume-se aqui que a inflação depende da inflação passada, das expectativas de inflação, da taxa básica nominal de juros da economia (Selic), do nível de crédito bancário, do hiato do produto e do câmbio:

$\pi_{\mathrm{t}}=\mathrm{f}\left\{\pi_{\mathrm{t}-\mathrm{i}}, \mathrm{E}_{\mathrm{t}-1}\left(\pi_{\mathrm{t}}\right), \mathrm{i}_{\mathrm{t}}, \mathrm{c}_{\mathrm{t}}, \mathrm{h}_{\mathrm{t}}, \mathrm{e}_{\mathrm{t}}\right\}$

Onde: $\pi_{t}, E_{t-1}\left(\pi_{t}\right), i_{t}, c_{t}, h_{t}, e_{t}$ representam a inflação, a expectativa para a inflação, a taxa básica de juros, o volume de crédito concedido pelo sistema financeiro, o hiato do produto e o preço internacional convertido em moeda doméstica, respectivamente.

No caso do modelo vetorial de correção de erros (VECM), a inflação foi medida pelo logaritmo natural $(\ln )$ da variação trimestral do índice de preços ao consumidor amplo (IPCA); a taxa básica nominal de juros da economia é o ln da Selic anualizada medida no final do período; a variável de crédito representa o (logaritmo natural) do saldo total das operações de crédito, em R \$ milhões, concedidas por instituições financeiras em operação no país; o hiato do produto foi obtido mediante a diferença entre as séries dessazonalizadas do PIB efetivo e do PIB potencial (ambos em logaritmo natural), este último extraído a partir da tendência linear do produto ao longo do tempo; o preço internacional convertido em moeda doméstica é o (logaritmo natural) do resultado do produto entre a cotação média do dólar nominal no período e o producer price index-commodities (PPI), publicado pelo Bureau of Labor Statistics (BLS), dos Estados Unidos. A variável $\pi_{\mathrm{t}-\mathrm{i}}$ capta o componente inercial da inflação. Para as estimações empreendidas com o uso do modelo irrestrito de correção de 
erros (UECM), as variáveis foram especificadas como acima, exceto pela inflação, representada pelo ln do próprio índice trimestral do IPCA, e pela Selic, utilizada em percentual; incluiu-se, ademais, a expectativa para a inflação, extraída do relatório Focus publicado semanalmente pelo Bacen, representando a previsão do mercado para a inflação acumulada no trimestre, lida com um período de defasagem.

Todos os dados são trimestrais, de modo a minimizar eventual volatilidade inerente a séries com maior frequência de observações, e referem-se ao período entre 1999.3 e 2015.3, perfazendo, portanto, 65 observações. O termo de início da amostra foi propositalmente selecionado, evitando-se recorrer a observações anteriores a 1999, dado que a mudança de regime observada naquele ano "trouxe uma alteração substancial nos mecanismos de transmissão monetária no Brasil” (MINELLA e SOUZA-SOBRINHO, 2011, p. 41). As tabelas 4.1 e 4.2, abaixo, trazem informações adicionais sobre as séries selecionadas.

Tabela 4.1 - Descrição das séries temporais e fontes de dados

\begin{tabular}{|c|c|c|}
\hline Variável $^{(1)}$ & Descrição & Fonte $^{(2)}$ \\
\hline Índice de inflação $(\pi)$ & $\begin{array}{c}\text { Índice nacional de preços ao } \\
\text { consumidor-amplo (IPCA) - } \\
\text { número índice (dez } 1993= \\
100)\end{array}$ & IBGE \\
\hline Taxa básica nominal de juros (i) & $\begin{array}{c}\text { Taxa de juros Selic anualizada } \\
\text { base } 252\end{array}$ & BCB1178 \\
\hline Crédito (c) & $\begin{array}{c}\text { Saldo das operações de } \\
\text { crédito das instituições } \\
\text { financeiras sob controle } \\
\text { público (R\$ milhões) } \\
+ \\
\text { Saldo das operações de } \\
\text { crédito das instituições } \\
\text { financeiras sob controle } \\
\text { privado (R\$ milhões) }\end{array}$ & $\begin{array}{l}\text { BCB2007 } \\
\text { BCB2043 }\end{array}$ \\
\hline Hiato do produto $(\mathrm{h})$ & $\begin{array}{l}\text { Obtido a partir da extração da } \\
\text { tendência linear do produto, } \\
\text { utilizando-se o índice } \\
\text { dessazonalizado do PIB a } \\
\text { preços de mercado }\end{array}$ & BCB22109 \\
\hline $\begin{array}{l}\text { Preço internacional convertido } \\
\text { em moeda doméstica (e) }\end{array}$ & $\begin{array}{c}\text { Taxa de câmbio - Livre - } \\
\text { Dólar americano (venda) - } \\
\text { diário- u.m.c./US\$ (média } \\
\text { trimestral) } \\
* \\
\text { Producer Price Index- } \\
\text { Commodities - Original data } \\
\text { value }\end{array}$ & $\begin{array}{c}\text { BCB1 } \\
\text { BLSWPU00000000 }\end{array}$ \\
\hline
\end{tabular}




\begin{tabular}{|c|c|c|}
\hline Variável $^{(1)}$ & Descrição & Fonte $^{(2)}$ \\
\hline Expectativa para a inflação $\left(\mathrm{E}_{\mathrm{t}-1}\left(\pi_{\mathrm{t}}\right)\right)$ & $\begin{array}{l}\text { Expectativa IPCA Focus - } \\
\text { variação \% - Mediana - } \\
\text { Mensal, acumulada por } \\
\text { trimestre, com um período de } \\
\quad \text { defasagem }\end{array}$ & BCB FOCUS \\
\hline \multicolumn{3}{|c|}{ 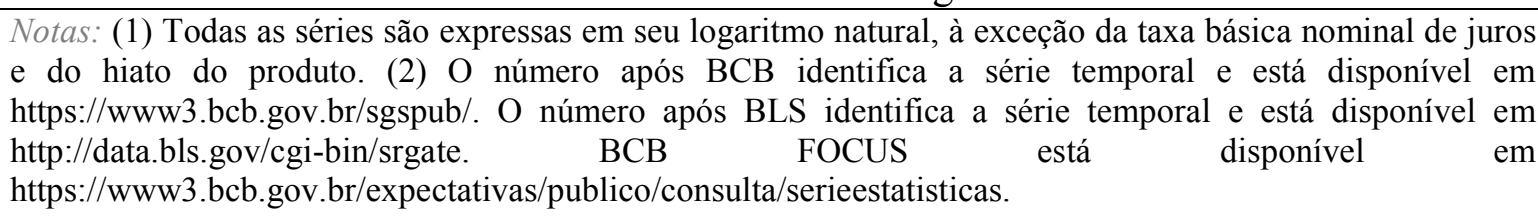 } \\
\hline
\end{tabular}

Tabela 4.2 - Estatística descritiva das variáveis. Amostra: 1999.3 - 2015.3

\begin{tabular}{lccccc}
\hline Variável & Média & Mediana & Mínimo & Máximo & Desvio Padrão \\
\hline$\pi$ & 7.88 & 7.89 & 7.34 & 8.38 & 0.28 \\
$\mathrm{i}$ & 14.17 & 13.65 & 7.16 & 26.32 & 4.54 \\
$\mathrm{c}$ & 13.71 & 13.67 & 12.56 & 14.96 & 0.81 \\
$\mathrm{~h}$ & -0.00 & 0.00 & -0.10 & 0.04 & 0.02 \\
$\mathrm{e}$ & 5.90 & 5.88 & 5.44 & 6.50 & 0.21 \\
$\mathrm{E}_{\mathrm{t}-1}\left(\pi_{\mathrm{t}}\right)$ & 0.01 & 0.01 & 0.00 & 0.02 & 0.00 \\
\hline
\end{tabular}

Para especificar a função apresentada em (4.1), tomou-se por base a literatura a seguir, que aponta os principais determinantes do movimento no nível de preços em geral, e no Brasil em particular, aduzindo-se a hipótese ora investigada acerca da relevância do crédito.

Carneiro et al (2002) utilizam modelagem que toma como base a Curva de Phillips backward looking, em que a taxa de inflação é explicada de forma linear por inflações passadas (a fim de capturar a inércia), pela desvalorização cambial corrente e por uma medida de nível de atividade. Os autores concluem que há evidências de que o repasse cambial para o IPCA ocorre de forma não linear.

Muinhos e Alves (2003) apresentam um modelo macroeconômico de média escala para a economia brasileira, em que mudanças na oferta e demanda agregadas, bem como nas expectativas do nível de preços e na taxa de câmbio, são os principais fatores potenciais que afetam o processo inflacionário.

Também destacando a importância das expectativas, Alves e Tombini (2006) apontam que a percepção dos agentes econômicos pode desencadear uma mudança no comportamento de famílias e firmas em relação à precificação e às decisões de consumo. Ademais, os resultados obtidos pelos autores apontam que os preços livres respondem basicamente à inflação passada, à inflação esperada e ao repasse cambial.

A sensibilidade da inflação à taxa básica de juros da economia, por seu turno, está no próprio cerne da concepção da política monetária e é premissa inerente ao regime de metas 
adotado pelo Banco Central, tendo recebido confirmação empírica em inúmeros estudos nacionais - e.g. Araújo et al (2015), Minella e Souza-Sobrinho (2011) e Siqueira (2007).

Por fim, Schwartzman (2006), estima um significativo impacto da taxa de câmbio sobre os preços de bens comercializáveis e monitorados.

\subsection{Estratégia econométrica}

Considerando os objetivos da presente pesquisa, isto é, verificar e mensurar eventual impacto do crédito sobre a inflação, no curto e longo prazos, lançou-se mão de um modelo autorregressivo de defasagens distribuídas (Autoregressive Distributed Lag - ARDL) para testar a hipótese de cointegração entre as variáveis e estimar a magnitude da influência dos determinantes da inflação, no equilíbrio. Além disso, foi empreendida a análise de funções resposta-impulso e da decomposição da variância dos erros de previsão, derivadas de um modelo vetorial de correção de erros (VECM). Apresenta-se de modo mais detalhado, a seguir, a metodologia econométrica utilizada.

\subsubsection{Cointegração}

Se determinados processos não estacionários movem-se juntos no longo prazo, embora cada um deles exiba tendência estocástica - traduzindo-se, portanto, em séries integradas de ordem $d$, ou I(d) -, então tais processos são guiados por uma tendência estocástica comum e são ditos cointegrados. No caso, a diferença entre as séries será estacionária, permitindo inferir um relacionamento causal entre séries não estacionárias (HARRIS, 1995, p. 6). Formalmente: "variáveis em um vetor $\mathrm{y}_{\mathrm{t}} \mathrm{k}$-dimensional são chamadas cointegradas de ordem $(\mathrm{d}, \mathrm{b})-\mathrm{y}_{\mathrm{t}} \sim \mathrm{CI}(\mathrm{d}, \mathrm{b})$, em notação - se todos os componentes de $\mathrm{y}_{\mathrm{t}}$ são $\mathrm{I}(\mathrm{d})$ e existe uma combinação linear $z_{t}=\beta^{\prime} y_{t}$, com $\beta=\left(\beta_{1}, \ldots, \beta_{k}\right)^{\prime} \neq 0$, tal que $z_{t}$ é $I(d-b)$ " (LÜTKEPOHL, 2005 , p. 245). O conceito de integração pode ser ampliado para admitir, em um sistema, variáveis estacionárias, de maneira que qualquer combinação linear $\mathrm{I}(0)$ de variáveis extraída desse sistema é referida como uma relação de cointegração (JOHANSEN, 1995; LÜTKEPOHL e KRÄTZIG, 2004). Nesse framework, $\beta$ recebe a denominação de vetor de cointegração.

Brooks (2008, p. 336) explica:

Muitas séries temporais são não estacionárias, mas se movem juntas ao longo do tempo - isto é, existem algumas influências sobre as séries (forças de mercado, 
por exemplo) implicando que elas estão vinculadas por alguma relação no longo prazo. Uma relação de cointegração pode também ser vista como um equilíbrio ou fenômeno de longo prazo, dada a possibilidade de que variáveis cointegradas desviem-se de seu equilíbrio no curto prazo, retornando, posteriormente, à sua associação de longo prazo (tradução livre).

Assim, o conceito de cointegração "mimetiza a existência de um equilíbrio de longo prazo para o qual um sistema econômico converge ao longo do tempo" (HARRIS, 1995, p. 6). É justamente essa interpretação - a possibilidade que a técnica oferece de capturar a noção econômica subjacente ao fenômeno - que desperta o interesse acerca da cointegração.

Desse modo, recorreu-se à análise de cointegração entre as séries temporais para testar a hipótese de que crédito e inflação estão relacionados no longo prazo. Yusof e Usman (2015) apontam que várias técnicas permitem a avaliação empírica acerca da existência de cointegração entre variáveis, indicando, entre os mais comuns, o procedimento de dois passos de Engle e Granger (1987), o teste do traço e do autovalor estabelecido por Johansen (1991) e o ARDL concebido por Pesaran et al (2001). Gjanci e Cërava (2014, p. 37) explicam que o ARDL "consiste em uma especificação dinâmica que inclui valores defasados da variável dependente e das variáveis explicativas, assim como valores contemporâneos das variáveis explicativas, para estimar relações tanto de curto quanto de longo prazo entre tais variáveis".

Segundo Bahmani-Oskooee e Nasir (2004), o primeiro passo para empreender a análise de equilíbrio de longo prazo é determinar a ordem de integração das variáveis envolvidas. Assim, após testes preliminares de estacionariedade (ver tabelas A1 a A3, no apêndice), constatou-se que as variáveis selecionadas são $\mathrm{I}(0)$ e I(1), notando-se alguns resultados conflitantes entre os testes utilizados. Conforme Eslamloueyan e Darvishi (2007, p. 111):

Se os testes de estacionariedade mostram que temos uma combinação de variáveis com diferentes graus de integração, os testes regulares de cointegração não serão adequados para verificar a presença de um eventual relacionamento de equilíbrio de longo prazo entre as variáveis (tradução livre).

Diante desse quadro, os autores sugerem a abordagem proposta por Pesaran et al (2001) para lidar com a questão, dado que o procedimento- denominado bounds test approach -, que toma por base um modelo ARDL, é capaz de testar a existência de relacionamento de longo prazo entre as variáveis independentemente se estas são estacionárias, integradas ou mutuamente cointegradas. Em suma, usa-se o teste $\mathrm{F}$ para examinar a significância de variáveis defasadas em um modelo irrestrito de correção de erros (Unrestricted Error Correction Model - UECM), espécie de modelo de defasagens distribuídas: caso a estatística computada esteja fora do intervalo apresentado por Pesaran et 
al, se podem fazer inferências conclusivas sem a necessidade de conhecer o estado de cointegração entre as variáveis subjacentes.

A literatura aponta diversas vantagens do método popularizado por Pesaran et al, se comparado às abordagens sugeridas por Engle e Granger (1987) e Johansen (1991). Em primeiro lugar, essas duas últimas alternativas "necessitam que as variáveis subjacentes sejam integradas de ordem (0) ou (1). Isso inevitavelmente envolve testes preliminares, introduzindo um grau de incerteza que pode afetar a análise dos relacionamentos de longo prazo" (YUSOF e USMAN, 2015, p. 90).

Explica-se:

ao se aplicarem testes convencionais de raiz unitária como Dickey Fuller Aumentado ou Phillips-Perron, pode-se incorretamente concluir que uma raiz unitária está presente numa série que é, na verdade, estacionária ao redor de uma quebra estrutural singular. O ARDL é útil, então, pois evita esse problema (PAHLAVANI, et al, 2005, p. 1160) (tradução livre).

Ademais, todas as variáveis são assumidas endógenas e os coeficientes de curto e longo prazos do modelo são estimados simultaneamente (DRITSAKIS, 2011).

O modelo, ainda, exibe robustez em face de eventuais problemas de autocorrelação, desde que "as ordens de defasagem sejam adequadamente escolhidas com base em alguma informação a priori, ou estimadas usando um processo de seleção tal como o Akaike Information Criterion (AIC) ou o Schwarz-Bayesian Criterion (SIC)" (YUSOF e USMAN, 2015, p. 90-91).

Pahlavani et al (2005, p. 1159) aduzem que o procedimento consiste em uma abordagem "mais estatisticamente significante para determinação de cointegração em pequenas amostras, enquanto a técnica de Johansen ainda exige grandes amostras para assegurar sua validade". Os autores prosseguem na indicação de vantagens do modelo ARDL:

Uma outra dificuldade da técnica de cointegração de Johansen que o modelo ARDL evita diz respeito ao grande número de escolhas que precisam ser feitas. Isso inclui, por exemplo, decisões relativas ao número de variáveis endógenas e exógenas (se existentes) a serem incluídas, o tratamento de elementos determinísticos, assim como a ordem do VAR e o número ótimo de defasagens que deve ser especificado. Os resultados empíricos são, geralmente, muito sensíveis ao método e às várias escolhas alternativas disponíveis no procedimento de estimação. Finalmente, com o ARDL admite-se que diferentes variáveis tenham diferentes defasagens ótimas, enquanto em modelos do tipo Johansen isso não é possível (PAHLAVANI et al, 2005, p. 1160) (tradução livre).

Por fim, Cakan e Mona (2013, p. 8) anotam, também em benefício da adoção do ARDL, que "o modelo de correção de erros (ECM) pode ser derivado a partir do ARDL mediante uma simples transformação linear, o que integra ajustes de curto prazo ao equilíbrio de longo prazo sem perda de informação". 
Tomando em consideração tais observações, e tendo em conta as características específicas das séries de tempo selecionadas para o estudo, bem como os objetivos da pesquisa, adotou-se o modelo de defasagens distribuídas para o teste de cointegração, seguindo a abordagem proposta por Pesaran et al (2001).

\subsubsection{ARDL e bounds test approach}

Conforme Choong et al (2005), que sumaziram Pesaran et al (2001), o modelo ARDL pode ser expresso como um VAR de ordem $p-\operatorname{VAR}(\mathrm{p})$ :

$$
\mathrm{z}_{\mathrm{t}}=\alpha_{0}+\mu \tau+\sum_{i=1}^{p} \eta_{\mathrm{i}} z_{\mathrm{t}-\mathrm{i}}+\varepsilon_{\mathrm{t}}
$$

\section{Onde:}

$\mathrm{Z}_{\mathrm{t}}$ representa um vetor coluna de dimensão $\mathrm{k}+1$, composto de variáveis dependentes e independentes $-\mathrm{y}_{\mathrm{t}}$ é a variável dependente e $\mathrm{x}_{\mathrm{t}} \mathrm{e}$ um vetor coluna de $\mathrm{k}$ variáveis explicativas;

$\alpha_{0}$ e $\mu$ são vetores de termos constantes com $\mathrm{k}+1$ componentes;

$\tau$ representa o termo temporal linear;

$\eta_{\mathrm{i}}$ é uma matriz $(\mathrm{k}+1) \times(\mathrm{k}+1)$ de parâmetros VAR para as defasagens $i$;

p indica a defasagem ótima máxima (número de lags) para as variáveis do sistema;

$\varepsilon_{\mathrm{t}}$ é um vetor coluna com $\mathrm{k}+1$ elementos que captura os resíduos da regressão, de modo que $\varepsilon_{\mathrm{t}}=\left[\varepsilon_{1 \mathrm{t}}, \ldots, \varepsilon_{\mathrm{k}+1 \mathrm{t}}\right]^{\prime} \sim \mathrm{IN}(0, \Omega)$ e $\Omega$ é positiva definida.

A equação (4.2) pode ser reescrita na forma de um modelo vetorial de correção de erros (VECM):

$$
\Delta \mathrm{z}_{\mathrm{t}}=\alpha_{0}+\mu \tau+\Pi \mathrm{z}_{\mathrm{t}-1}+\sum_{i=1}^{p-1} \Gamma_{\mathrm{i}} \Delta \mathrm{z}_{\mathrm{t}-\mathrm{i}}+\varepsilon_{\mathrm{t}}
$$

Em que:

$\Pi=-\left(\mathrm{I}-\sum_{i=1}^{p} \eta_{\mathrm{i}}\right)$ é o multiplicador matricial de longo prazo;

$\Gamma_{\mathrm{i}}=-\sum_{j=i+1}^{p} \eta_{\mathrm{j}}$ representa a matriz das repostas de curto prazo;

$\Delta$ é o operador de primeiras diferenças; e

I é a matriz identidade. 
O modelo assume uma única relação de longo prazo entre as variáveis (CHOONG et al, 2005, p. 16). Adotando-se essa premissa, e seguindo as assunções de Pesaran et al (2001) para o caso II (com intercepto restrito e sem tendência), especificou-se o seguinte UECM para o caso concreto:

$$
\begin{aligned}
& \Delta \pi_{\mathrm{t}}=\alpha_{0}+\sum_{i=1}^{n} \alpha_{1 \mathrm{i}} \Delta \pi_{\mathrm{t}-\mathrm{i}}+\sum_{j=0}^{p} \alpha_{2 \mathrm{i}} \Delta \mathrm{i}_{\mathrm{t}-\mathrm{j}}+\sum_{k=0}^{q} \alpha_{3 \mathrm{i}} \Delta \mathrm{c}_{\mathrm{t}-\mathrm{k}}+ \\
& \sum_{l=0}^{r} \alpha_{4 \mathrm{i}} \Delta \mathrm{h}_{\mathrm{t}-1}+\sum_{m=0}^{s} \alpha_{5 \mathrm{i}} \Delta \mathrm{e}_{\mathrm{t}-\mathrm{m}}+\sum_{o=0}^{v} \alpha_{6 \mathrm{i}} \Delta \mathrm{E}_{\mathrm{t}-1}\left(\pi_{\mathrm{t}}\right)_{\mathrm{t}-\mathrm{o}}+\delta_{1} \pi_{\mathrm{t}-1} \\
& \delta_{2} \mathrm{i}_{\mathrm{t}-1}+\delta_{3} \mathrm{c}_{\mathrm{t}-1}+\delta_{4} \mathrm{~h}_{\mathrm{t}-1}+\delta_{5} \mathrm{e}_{\mathrm{t}-1}+\delta_{6} \mathrm{E}_{\mathrm{t}-1}\left(\pi_{\mathrm{t}}\right)_{\mathrm{t}-1}+\varepsilon_{\mathrm{t}}
\end{aligned}
$$

Assim, em (4.4), $n, p, q, r, s, v$ indicam a extensão da defasagem ótima (número de lags) para cada variável, $\alpha_{\mathrm{i}}$ são parâmetros que captam a dinâmica de curto prazo do modelo, enquanto $\delta_{\mathrm{i}}$ servem como multiplicadores de longo prazo. O termo $\varepsilon_{\mathrm{t}}$ é o erro do modelo. Previamente à estimação propriamente dita, faz-se necessário, portanto, definir a combinação que representa a melhor escolha entre o número ótimo de períodos de defasagem para cada variável. Com base na minimização da estatística proposta por Akaike (1973) - critério AIC, (Akaike information criterion) -, limitando-se a análise a quatro lags máximos em virtude do tamanho da amostra, as ordens $(n, p, q, r, s, v)$ estimadas para as variáveis $\left(\pi_{\mathrm{t}}, \mathrm{i}_{\mathrm{t}}, \mathrm{c}_{\mathrm{t}}, \mathrm{h}_{\mathrm{t}}, \mathrm{e}_{\mathrm{t}}, \mathrm{E}_{\mathrm{t}}\right.$ $\left.{ }_{1}\left(\pi_{\mathrm{t}}\right)\right)$ no modelo ARDL especificado em (4.4) foram $(3,4,3,4,1,3)$, dentre 12500 possibilidades avaliadas.

Yusof e Usman (2015) indicam que a implementação do bounds test approach - cujos fundamentos foram apresentados na seção 4.1 - deve obedecer a quatro estágios: primeiro, certifica-se a existência de cointegração entre as variáveis utilizando-se um modelo de correção de erros (ECM); uma vez confirmada a cointegração, estima-se o relacionamento de longo prazo entre as variáveis, servindo-se do modelo ARDL; o terceiro passo consiste em estimar o ECM associado ao modelo ARDL; ao final, a adequação do ARDL é verificada mediante testes de robustez e estabilidade.

A eventual existência de relacionamento de longo prazo, i.e., cointegração entre as variáveis é aferida mediante o uso da estatística $\mathrm{F}$ (Teste de Wald), estabelecendo-se a seguinte hipótese nula $\left(\mathrm{H}_{0}\right): \delta_{1}=\delta_{2}=\delta_{3}=\delta_{4}=\delta_{5}=\delta_{6}=0$. Sob $\mathrm{H}_{0}$, não há relacionamento de nível no longo prazo. A estatística $F$ computada - cuja distribuição não é padrão - é, então, 
comparada com os valores críticos do intervalo proposto por Pesaram et al (2001): caso o valor esteja acima do limite superior, rejeita-se a hipótese nula; caso esteja abaixo, $\mathrm{H}_{0}$ não pode ser rejeitada; por fim, se a estatística estiver dentro do intervalo, o teste é inconclusivo (NOWAK e BISTA, 2014).

Cumprida a primeira etapa e evidenciada a hipótese de cointegração, passa-se à estimação do modelo ARDL adequado, para fins de obtenção e interpretação dos resultados de longo prazo. Como, no equilíbrio o sistema é estável, por definição, temos:

$$
\begin{aligned}
& \sum_{i=1}^{n} \alpha_{1 \mathrm{i}} \Delta \pi_{\mathrm{t}-\mathrm{i}}=\sum_{j=0}^{p} \alpha_{2 \mathrm{i}} \Delta \mathrm{i}_{\mathrm{t}-\mathrm{j}}=\sum_{k=0}^{q} \alpha_{3 \mathrm{i}} \Delta \mathrm{c}_{\mathrm{t}-\mathrm{k}}=\sum_{l=0}^{r} \alpha_{4 \mathrm{i}} \Delta \mathrm{h}_{\mathrm{t}-\mathrm{l}}= \\
& \sum_{m=0}^{s} \alpha_{5 \mathrm{i}} \Delta \mathrm{e}_{\mathrm{t}-\mathrm{m}}=\sum_{o=0}^{v} \alpha_{6 \mathrm{i}} \Delta \mathrm{E}_{\mathrm{t}-1}\left(\pi_{\mathrm{t}}\right)_{\mathrm{t}-\mathrm{o}}=0
\end{aligned}
$$

Então, substituindo (4.5) em (4.4):

$$
\pi_{\mathrm{t}-1}=\alpha_{0}+\gamma_{2} \mathrm{i}_{\mathrm{t}-1}+\gamma_{3} \mathrm{c}_{\mathrm{t}-1}+\gamma_{4} \mathrm{~h}_{\mathrm{t}-1}+\gamma_{5} \mathrm{e}_{\mathrm{t}-1}+\gamma_{6} \mathrm{E}_{\mathrm{t}-1}\left(\pi_{\mathrm{t}}\right)_{\mathrm{t}-1}+\mathrm{v}_{\mathrm{t}}
$$

Com $\gamma_{\mathrm{i}}=-\left(\delta_{\mathrm{i}} / \delta_{1}\right), \mathrm{i} \in[2,6], \alpha_{0}=-\delta_{1}{ }^{-1} \alpha_{0}$ e $v_{\mathrm{t}}=-\delta_{1}{ }^{-1} \varepsilon_{\mathrm{t}}$. Desse modo, a partir das estimativas obtidas com o modelo ARDL, obtém-se os coeficientes $\left(\gamma_{\mathrm{i}}\right)$ que denotam o relacionamento de longo prazo entre as variáveis.

Segue-se à terceira fase: substituindo-se as variáveis defasadas em (4.4) pelo resíduo $v_{t}$ decorrente da estimação de (4.6) - referido por termo de correção de erros - obtém-se o modelo de correção de erros (ECM) restrito correspondente ao ARDL:

$$
\begin{aligned}
& \Delta \pi_{\mathrm{t}}=\alpha_{0}+\sum_{i=1}^{n} \alpha_{1 \mathrm{i}} \Delta \pi_{\mathrm{t}-\mathrm{i}}+\sum_{j=0}^{p} \alpha_{2 \mathrm{i}} \Delta \mathrm{i}_{\mathrm{t}-\mathrm{j}}+\sum_{k=0}^{q} \alpha_{3 \mathrm{i}} \Delta \mathrm{c}_{\mathrm{t}-\mathrm{k}}+ \\
& \sum_{l=0}^{r} \alpha_{4 \mathrm{i}} \Delta \mathrm{h}_{\mathrm{t}-\mathrm{l}}+\sum_{m=0}^{s} \alpha_{5 \mathrm{i}} \Delta \mathrm{e}_{\mathrm{t}-\mathrm{m}}+\sum_{o=0}^{v} \alpha_{6 \mathrm{i}} \Delta \mathrm{E}_{\mathrm{t}-1}\left(\pi_{\mathrm{t}}\right)_{\mathrm{t}-\mathrm{o}}+\varphi v_{\mathrm{t}-1}+\mathrm{u}_{\mathrm{t}}
\end{aligned}
$$

Dado que o modelo em (4.7) representa a dinâmica de retorno a um equilíbrio de longo prazo, é esperado que $\varphi$ tenha sinal negativo para assegurar a convergência e seja menor que a unidade, em módulo. Ademais, $\varphi$ pode ser interpretado como o parâmetro de velocidade de ajuste ao equilíbrio (DAVIDSON et al, 1978).

Por fim, na última etapa são empreendidos testes de diagnóstico para correlação serial, especificação da forma funcional, normalidade e heterocedasticidade dos resíduos, além de 
testes de estimação recursiva para examinar a estabilidade estrutural dos parâmetros do modelo.

\subsubsection{Funções resposta-impulso}

Funções resposta-impulso, como se depreende da própria denominação, "exibem a resposta de cada uma das variáveis do sistema a um choque em quaisquer das outras variáveis" (BEN-KAABIA et al, 2002, p. 40), revelando-se úteis para examinar o comportamento de variáveis de interesse ao longo do tempo, diante de uma perturbação dentro do sistema. Assim, em linha com os objetivos da pesquisa, adotou-se a análise das funções resposta-impulso (FRI) visando a testar a existência de relacionamento e descrever a dinâmica de curto prazo entre crédito e inflação.

Admitida a hipótese de cointegração, as FRI são obtidas a partir de um VECM da forma expressa em (4.3), representado por um processo média móvel (moving average - MA) de ordem infinita (PESARAN e SHIN, 1999):

$$
\Delta \mathrm{z}_{\mathrm{t}}=\sum_{i=0}^{\infty} \Psi_{\mathrm{i}} \varepsilon_{\mathrm{t}-\mathrm{i}}
$$

Onde $\Psi_{\mathrm{i}}$ representa uma matriz de coeficientes que pode ser obtida recursivamente usando $\Psi_{\mathrm{i}}=\eta_{1} \Psi_{\mathrm{i}-1}+\eta_{2} \Psi_{\mathrm{i}-2}+\ldots+\eta_{\mathrm{p}} \Psi_{\mathrm{i}-\mathrm{p}}$, para $\mathrm{i}=1,2, \ldots$, com $\Psi_{\mathrm{i}}=0$ para $\mathrm{i}<0$ e $\Psi_{0}=\mathrm{I}_{\mathrm{k}}$.

Lütkepohl (2005, p. 264) assevera:

Uma notável característica das resposta impulso [em um VECM] é que elas não retornam a zero com o passar do tempo após o choque, mas aproximam-se de algum valor não nulo. Claramente, isso reflete a não estacionariedade do sistema, no qual um impulso único pode ter efeitos permanentes (tradução livre).

No mesmo sentido: Alter e Schüler (2011), Arfanuzzaman (2014), Kaliontzakis (2015) e Akram e Li (2016), dentre outros.

Pesaran e Shin (1998) lembram que, dada a necessidade de tornar independentes os erros do sistema, a decomposição de Cholesky é rotineiramente aplicada para "ortogonalizar" funções impulso-resposta e, a partir daí, proceder à análise dinâmica de modelos de vetores autorregressivos. Tal método, contudo, impõe uma ordenação causal recursiva entre as variáveis "que somente se justifica sob assunções predeterminadas não passíveis de serem testadas na ausência de restrições prévias derivadas da teoria" (COOLEY e LeROY, 1985, p. 301). Ademais, as FRI obtidas são sensíveis à ordenação causal - um VAR(p) com n variáveis permite $\mathrm{n}$ ! arranjos e "não há uma diretriz clara acerca de qual dessas possíveis parametrizações deveria ser usada" (PESARAN e SHIN, 1998, p. 3) - o que enfraquece a validade dos resultados obtidos. 
De maneira a contornar tais fragilidades, utilizou-se a função resposta-impulso generalizada (FRIG) proposta por Pesaran e Shin (1998). Os autores enfatizam que a FRIG são únicas - não variam com a reordenação das variáveis do VAR - e "consideram inteiramente os padrões históricos das correlações observadas entre os diferentes choques" (PESARAN e SHIN, 1998, p. 4).

Warne (2008) aduz que a FRIG não requer a identificação de choques estruturais, evitando a crítica de Cooley e LeRoy. Mendonça e Silva (2008, p. 6) apontam, ainda, duas vantagens na aplicação do método concebido por Pesaran e Shin:

(i) a função de impulso-resposta generalizada fornece resultados mais robustos do que o método ortogonalizado, e (ii) devido ao fato de a ortogonalidade não ser imposta, a função impulso-resposta generalizada permite interpretar de forma mais acurada a resposta do impacto inicial decorrente de cada choque causado por uma variável sobre as demais.

A abordagem pode ser brevemente resumida como se segue (PESARAN e SHIN, 1998).

A FRIG é descrita como o resultado de um experimento conceitual em que o perfil temporal da economia, após ser atingida em $t$ por um hipotético vetor ( $\mathrm{k} \times 1)$ de choques de tamanho $\zeta=\left(\zeta_{1}, \ldots, \zeta_{\mathrm{m}}\right)^{\prime}$, é comparado ao perfil contrafactual dessa economia em $t+n$, delineado por um baseline que incorpora o histórico do sistema econômico subjacente. São considerados, assim, os choques que atingem a economia em $t$, bem como os choques esperados entre $t+1$ e $t+n$, além do estado prevalente da economia no momento anterior aos choques (em $t-1)$.

Nestes termos, a função resposta-impulso generalizada de $z_{\mathrm{t}}$ no horizonte temporal $n$ é definida por:

$\mathrm{FRIG}_{\mathrm{z}}\left(\mathrm{n}, \zeta, \Lambda_{\mathrm{t}-1}\right)=\mathrm{E}\left(\mathrm{z}_{\mathrm{t}+\mathrm{n}} \mid \varepsilon_{\mathrm{t}}=\zeta, \Lambda_{\mathrm{t}-1}\right)-\mathrm{E}\left(\mathrm{z}_{\mathrm{t}+\mathrm{n}} \mid \Lambda_{\mathrm{t}-1}\right)$

denotando por $\Lambda_{\mathrm{t}-1}$ o conjunto informacional não-decrescente que contém o histórico da economia até o horizonte $t-1$. No caso de (4.8), a FRIG seria dada por

$\mathrm{FRIG}_{\Delta \mathrm{z}}\left(\mathrm{n}, \zeta, \Lambda_{\mathrm{t}-1}\right)=\Psi_{\mathrm{n}} \zeta$

Alternativamente a um choque em todos os elementos de $\varepsilon_{t}$, pode-se considerar uma perturbação apenas em seu j-ésimo elemento, fazendo $\varepsilon_{\mathrm{jt}}=\zeta_{\mathrm{j}}$, e incorporar os efeitos de outros choques usando uma distribuição dos erros (que pode ser assumida ou derivada da observação histórica). Desse modo, fixando $\zeta_{\mathrm{j}}=\sigma_{\mathrm{jj}}^{1 / 2}$ e após alguma manipulação, a resposta-impulso generalizada passa a ser dada por:

$\operatorname{FRIG}_{\Delta z, j}(\mathrm{n})=\Psi_{\mathrm{n}} \Omega 1_{\mathrm{j}} \sigma_{\mathrm{jj}}{ }^{-1 / 2}$ 
Com $\Omega=E\left(\varepsilon_{\mathrm{t}} \varepsilon_{\mathrm{t}}{ }^{\prime}\right), \sigma_{\mathrm{jj}}=\mathrm{E}\left(\varepsilon_{\mathrm{jt}}{ }^{2}\right)$. lj é a j-ésima coluna da matriz identidade $\mathrm{I}_{\mathrm{k}}$, representando o vetor seleção do choque com tamanho de um desvio-padrão.

Assim, (4.11) mede o efeito, sobre $\Delta \mathrm{z}_{\mathrm{t}+\mathrm{n}}$, de um choque aplicado à j-ésima equação em (4.8). O gráfico da FRIG é, então, obtido como de costume, plotando-se os resultados no eixo y do plano, com o perfil temporal sobre o eixo x.

\subsubsection{Decomposição da variância dos erros de previsão}

Para se determinar quanto da variância do erro de previsão de uma dada variável, no nésimo período à frente (para $\mathrm{n}=1,2, \ldots$ ), é explicado por inovações em cada variável explicativa, recorre-se à decomposição da variância dos erros de previsão (DVEP). Dado que uma perturbação em determinada variável irá afetá-la diretamente e, além disso, será transmitida às demais variáveis do sistema mediante a estrutura dinâmica do VAR, a DVEP “dá a proporção dos movimentos nas variáveis dependentes que são devidos a choques em si próprias, em contraposição a choques em outras variáveis” (BROOKS, 2008, p. 300).

Segundo Dees et al, "tradicionalmente, a DVEP de um modelo VAR é executada a partir de um conjunto de choques ortogonais por meio dos quais é calculada a contribuição da j-ésima inovação ortogonalizada ao erro quadrado médio da previsão, para o n-ésimo período à frente" (2007, p. 18). Entretanto, dadas as já apontadas dificuldades inerentes a esse método de identificação, Lanne e Nyberg (2014) propõem uma DVEP generalizada (DVEPG) que toma por base o conceito da FRIG descrita na seção anterior.

Para um choque $j$, variável $z$, horizonte $n(\mathrm{n}=0,1,2, \ldots)$ e histórico da economia representado por $\Lambda_{\mathrm{t}-1}$, a DVEPG é obtida como função da FRIG dada por (4.11), conforme a seguir:

$$
\operatorname{DVEPG}_{\mathrm{jz},} \Lambda_{\mathrm{t}-1}(\mathrm{n})=\frac{\sum_{t=0}^{\mathrm{n}} \operatorname{FRIG}\left(\mathrm{t}, \zeta_{\mathrm{j}}, \Lambda_{\mathrm{t}-1}\right)_{\mathrm{z}}^{2}}{\sum_{j=1}^{\mathrm{k}} \sum_{t=0}^{\mathrm{n}} \operatorname{FRIG}\left(\mathrm{t}, \zeta_{\mathrm{j}}, \Lambda_{\mathrm{t}-1}\right)_{\mathrm{z}}^{2}}, \quad \mathrm{j}, \mathrm{z}=1, \ldots, \mathrm{k}
$$

Em (4.14), o denominador mede o efeito agregado acumulado de todos os choques, enquanto o numerador indica o efeito acumulado do j-ésimo choque. Por construção, (4.14) está limitada entre 0 e 1, medindo a contribuição relativa do j-ésimo choque em relação ao impacto total de todos os $\mathrm{k}$ choques depois de $\mathrm{n}$ períodos sobre a j-ésima variável em $\mathrm{z}_{\mathrm{t}}$ (LANNE e NYBERG, 2014, p. 4-5). 
A análise da DVEPG, conforme acima explicado, será utilizada para mensurar a influência, no curto prazo, dos movimentos no crédito sobre a inflação e as demais variáveis relevantes. 


\section{RESULTADOS}

Neste capítulo comentam-se os resultados das estimações empreendidas com o uso das técnicas indicadas na seção anterior. Conforme antecipado no capítulo introdutório, a hipótese de que crédito e inflação estão relacionados no longo prazo foi verificada mediante a utilização de um modelo ARDL, cujas conclusões são objeto da primeira subseção adiante. A análise das funções resposta-impulso e da decomposição da variância dos erros de previsão é apresentada nas demais subseções que compõem o capítulo.

\subsection{ARDL}

Antes de adentrar na interpretação dos resultados obtidos a partir da estimação do modelo ARDL, apresentam-se os outputs do teste de Wald balizado pelos valores críticos do intervalo proposto por Pesaran et al (2001) - $1^{\text {a }}$ etapa da implementação da metodologia, conforme explicado na subseção 4.2.2.

A tabela 5.1 exibe os resultados do teste, que demonstram a presença de relacionamento de longo prazo entre a inflação e as variáveis independentes selecionadas para o caso brasileiro.

Tabela 5.1 - Resultados do teste para análise de cointegração (bounds test approach)

\begin{tabular}{lcc}
\hline Estatística F computada (Teste de Wald): & $\mathrm{F}(7,37)=11.3078$ \\
$\mathrm{H}_{0}: \delta_{1}=\delta_{2}=\delta_{3}=\delta_{4}=\delta_{5}=\delta_{6}=0$ & & \\
\hline & limite inferior, & limite superior, \\
Valores críticos do intervalo para a estatística $\mathrm{F}$ & $\mathrm{I}(0)$ & $\mathrm{I}(1)$ \\
$1 \%$ de significância $(\mathrm{k}=5)$ & 3.06 & 4.15 \\
\hline ota: Os valores críticos reportados são oriundos de Pesaran et al $(2001)$, Tabela C1.ii (caso II: com intercepto \\
\end{tabular}

Aceita a hipótese de cointegração, passa-se à discussão dos resultados. A Tabela 5.2 apresenta os coeficientes estimados pelo modelo de correção de erros (ECM) restrito correspondente ao ARDL.

Tabela 5.2 - Coeficientes de curto prazo ECM. Var. dependente: $\Delta \pi_{\mathrm{t}}$ Período: 1999.3-2015.3

\begin{tabular}{lccc}
\hline Regressor & Coeficiente & Erro padrão & Estatística t \\
\hline$\Delta \pi_{\mathrm{t}-1}$ & -0.17 & 0.11 & -1.56 \\
$\Delta \pi_{\mathrm{t}-2}$ & -0.31 & 0.08 & $-3.52 * * *$ \\
$\Delta \mathrm{i}_{\mathrm{t}}$ & 0.00 & 0.00 & $4.66^{* * *}$ \\
$\Delta \mathrm{i}_{\mathrm{t}-1}$ & -0.00 & 0.00 & -1.12 \\
$\Delta \mathrm{i}_{\mathrm{t}-2}$ & -0.00 & 0.00 & $-3.21 * * *$ \\
\hline
\end{tabular}




\begin{tabular}{lccc}
\hline Regressor & Coeficiente & Erro padrão & Estatística t \\
\hline$\Delta \mathrm{i}_{\mathrm{t}-3}$ & -0.00 & 0.00 & $-1.89 *$ \\
$\Delta \mathrm{c}_{\mathrm{t}}$ & 0.08 & 0.02 & $3.20 * * *$ \\
$\Delta \mathrm{c}_{\mathrm{t}-1}$ & 0.09 & 0.02 & $4.16^{* * *}$ \\
$\Delta \mathrm{c}_{\mathrm{t}-2}$ & 0.06 & 0.02 & $2.24 * *$ \\
$\Delta \mathrm{h}_{\mathrm{t}}$ & 0.15 & 0.06 & $2.42 * *$ \\
$\Delta \mathrm{h}_{\mathrm{t}-1}$ & 0.22 & 0.07 & $2.87 * * *$ \\
$\Delta \mathrm{h}_{\mathrm{t}-2}$ & 0.08 & 0.06 & 1.24 \\
$\Delta \mathrm{h}_{\mathrm{t}-3}$ & 0.13 & 0.06 & $2.01 *$ \\
$\Delta \mathrm{e}_{\mathrm{t}}$ & -0.01 & 0.01 & -1.18 \\
$\Delta \mathrm{E}_{\mathrm{t}-1}\left(\pi_{\mathrm{t}}\right)_{\mathrm{t}}$ & 0.44 & 0.21 & $2.05 * *$ \\
$\Delta \mathrm{E}_{\mathrm{t}-1}\left(\pi_{\mathrm{t}}\right)_{\mathrm{t}-1}$ & 0.76 & 0.18 & $4.02 * * *$ \\
$\Delta \mathrm{E}_{\mathrm{t}-1}\left(\pi_{\mathrm{t}}\right)_{\mathrm{t}-2}$ & 0.59 & 0.20 & $2.93 * * *$ \\
$v_{\mathrm{t}-1}(\mathrm{ECT})$ & -0.21 & 0.02 & $-9.59 * * *$ \\
\hline
\end{tabular}

Nota: Asteriscos $(*, * *, * * *)$ denotam significância estatística ao nível de $10 \%, 5 \%$ e $1 \%$, respectivamente.

Os coeficientes das primeiras diferenças $-\alpha_{i}$, em (4.7) - representam a dinâmica de ajuste e o respectivo impacto sobre a inflação, no curto prazo, das variáveis crédito, taxa básica nominal de juros, hiato do produto, preço internacional convertido em moeda doméstica e expectativas. Nota-se, em princípio, que os valores estimados para todas as variáveis explicativas possuem o sinal esperado e são estatisticamente significantes, à exceção da inflação com uma defasagem e do preço internacional, que não são, entretanto, estatisticamente significantes.

Perturbações positivas no volume de crédito concedido pelo sistema financeiro impactam a variação no índice de preços na mesma direção: um choque de crédito é inflacionário, no curto prazo. Os resultados sugerem conclusão análoga para os movimentos das variáveis hiato do PIB e expectativas de inflação.

Os coeficientes, em lags, referentes à variação da Selic são negativos, ilustrando o impacto esperado (e defasado) de um choque de política monetária sobre a inflação; foge a esta regra a estimativa que relaciona, contemporaneamente, a taxa básica de juros e o índice de preços: há aqui uma resposta positiva da inflação, de modo que, em um primeiro momento, o aumento dos juros é acompanhado por uma elevação nos preços da economia. Tais resultados refletem o price puzzle comumente observado em pesquisas dessa natureza (SIMS, 1992): referido fenômeno recebe esta denominação por representar, justamente, a trajetória inesperada que a inflação exibe diante de um aperto monetário, e pode advir de uma resposta branda do Banco Central a um aumento previsto nos preços, dentro da natural abordagem prospectiva das medidas adotadas pela autoridade monetária. Uma leitura alternativa oferece justificativa diversa para o enigma ao relacionar o aumento nos juros à elevação dos custos 
financeiros das empresas, que buscariam repassar os novos encargos aos preços de modo a preservar, ou recompor, suas margens de lucro (FERREIRA e JAYME JUNIOR, 2005).

O coeficiente associado ao error correction term (ECT) é negativo e altamente significante, como esperado, fato que reforça a existência de um relacionamento estável no longo prazo entre as variáveis em discussão. A magnitude do ECT indica a velocidade de ajustamento que restaura o equilíbrio no modelo dinâmico e, no caso, aponta que eventuais desvios do steady state provocados por choques em quaisquer variáveis são corrigidos moderadamente, a uma taxa de $21,8 \%$ a cada período; assim, o sistema demora cerca de três trimestres para absorver $50 \%$ do choque (meia-vida) que o desvia do equilíbrio de longo prazo.

$\mathrm{Na}$ Tabela 5.3, estão transcritos os coeficientes de longo prazo obtidos mediante a estimação de (4.6):

Tabela 5.3 - Coeficientes de longo prazo

\begin{tabular}{lccc}
\hline Regressor & Coeficiente & Erro padrão & Estatística t \\
\hline $\mathrm{i}_{\mathrm{t}-1}$ & 0.01 & 0.00 & $5.89^{* * *}$ \\
$\mathrm{c}_{\mathrm{t}-1}$ & 0.39 & 0.01 & $23.73^{* * *}$ \\
$\mathrm{~h}_{\mathrm{t}-1}$ & -0.29 & 0.26 & -1.09 \\
$\mathrm{e}_{\mathrm{t}-1}$ & 0.23 & 0.03 & $6.18^{* * *}$ \\
$\mathrm{E}_{\mathrm{t}-1}\left(\pi_{\mathrm{t}}\right)_{\mathrm{t}-1}$ & -0.13 & 1.86 & -0.07 \\
$\dot{\alpha}_{0}($ intercepto) & 0.95 & 0.22 & $4.32^{* * *}$ \\
\hline Nota: Asteriscos $(* * *)$ denotam significância estatística ao nível de $1 \%$. &
\end{tabular}

Da tabela, percebe-se que todos os coeficientes relativos ao relacionamento de longo prazo entre as variáveis são estatisticamente significantes, exceto pela estimativa das variáveis referente ao hiato do produto e às expectativas para inflação. Tal resultado ilustra com precisão o alcance do conceito ampliado de cointegração apresentado na seção 4.2.1 do capítulo anterior: o vetor de cointegração, que representa a relação de equilíbrio do sistema no longo prazo, admite a presença de variáveis estacionárias, desde que os parâmetros a elas associados sejam nulos, como é o caso para hiato e expectativas.

O sinal positivo exibido para a estimativa da Selic reforça a hipótese teórica de neutralidade da moeda no longo prazo, de modo que inflação e taxa básica nominal de juros estariam positivamente correlacionadas, nesse horizonte temporal. O resultado evidencia, portanto, o assim chamado Efeito Fisher, alinhando-se a estudos nacionais e internacionais que alcançaram conclusões análogas (CARNEIRO et al, 2003; MISHKIN, 1991).

Nota-se que o impacto do crédito sobre a inflação é substancial e positivo, como esperado, sugerindo que quando o nível absoluto de crédito cresce, a inflação aumenta. Este 
resultado reforça a teoria que destaca as pressões de demanda advindas de movimentos no mercado de crédito, e é consistente com o cenário de restrição de liquidez identificado em outros estudos para o caso brasileiro. Mais precisamente, verifica-se a seguinte elasticidade: um aumento de 1 ponto percentual no volume de crédito concedido pelo sistema financeiro provoca uma inflação de aproximadamente $0.39 \%$ no longo prazo. Noutras palavras, a magnitude da trajetória de crescimento do crédito total, da ordem de cerca de 33 p.p. entre dezembro de 2011 e dezembro de 2013, ocorrida no contexto das medidas albergadas pela Nova Matriz Macroeconômica, perturbaria a inflação de equilíbrio em 13 pontos percentuais; isto é, somente referida escalada recente no volume de crédito provocaria, sozinha, um movimento no nível de preços que, acumulado, superaria o dobro do centro da meta atual de inflação, tomado como nível de equilíbrio, dado o regime de metas em vigor. Tal resultado tem implicações políticas relevantes e indica a necessidade de se adotar uma abordagem parcimoniosa no que diz respeito à continuidade da expansão incentivada do crédito na economia nacional.

Os preços internacionais convertidos em moeda doméstica também se mostraram relevantes para a determinação da inflação no longo prazo. Uma desvalorização do Real e/ou um aumento do índice de preços externos que deprecie a moeda doméstica em 1\%, acarreta um aumento de $0.23 \%$ no índice de preços. Supõe-se que o menor impacto relativo da variável - se comparada aos efeitos do crédito - ocorra em virtude da presença não desprezível dos serviços e dos bens não-comercializáveis na cesta do índice de inflação, segmentos menos sujeitos aos reflexos das flutuações cambiais sobre o nível de preços praticados nos respectivos setores.

O coeficiente relativo às expectativas de inflação apresentou resultado contraintuitivo: o sinal negativo indica que um aumento na inflação esperada reduziria a inflação realizada, no longo prazo. Contudo, tal resultado é estatisticamente insignificante (p-valor 0.941), de modo que não parece influenciar o nível de inflação no estado estacionário, controlando-se para as demais variáveis - especialmente a própria inflação defasada - presentes no sistema estimado. O mesmo se pode dizer do resultado semelhante obtido para o hiato do produto: a não significância estatística da variável é aderente a recorrentes estudos empíricos no sentido de que, no longo prazo, o processo de autocorreção endógena da economia dirige o produto ao seu equilíbrio natural e, portanto, o hiato é estacionário e tende a zero, não impactando os movimentos no nível de preços.

Os testes de diagnóstico para correlação serial, especificação da forma funcional, normalidade e heterocedasticidade dos resíduos estão reunidos na tabela 5.4. Os resultados 
confirmam a validade de modelo: não há evidência de autocorrelação, a forma funcional foi corretamente especificada e os resíduos são normalmente distribuídos e possuem variância constante.

Tabela 5.4 - Testes de diagnóstico

\begin{tabular}{lcc}
\hline Teste & Estatística & p-valor \\
\hline A: Correlação serial & $\mathrm{X}^{2}(3)=0.1931$ & 0.9787 \\
B. Forma funcional & $\mathrm{F}(2,35)=2.3179$ & 0.1134 \\
C: Normalidade & $\mathrm{X}^{2}(2)=1.4589$ & 0.4821 \\
D: Heterocedasticidade & $\mathrm{F}(23,37)=1.1311$ & 0.3608 \\
\hline A: Teste LM de Breusch-Godfrey & & \\
B: Teste RESET de Ramsey usando o quadrado e o cubo do valor predito \\
C: Teste Jarque-Bera & & \\
D: Teste Breusch-Pagan-Godfrey & & \\
\hline
\end{tabular}

Adicionalmente, os resultados da aplicação de testes CUSUM e CUSUMSQ para examinar a estabilidade estrutural dos parâmetros estimados no modelo indicam que a equação está corretamente especificada. Os gráficos 5.1 e 5.2 explicitam que a hipótese nula de estabilidade estrutural não pode ser rejeitada, uma vez que a soma dos resíduos recursivos (e de seus quadrados) em regra permanece dentro do intervalo crítico a 5\% de significância.

Gráfico 5.1: Controle de soma acumulada dos resíduos recursivos

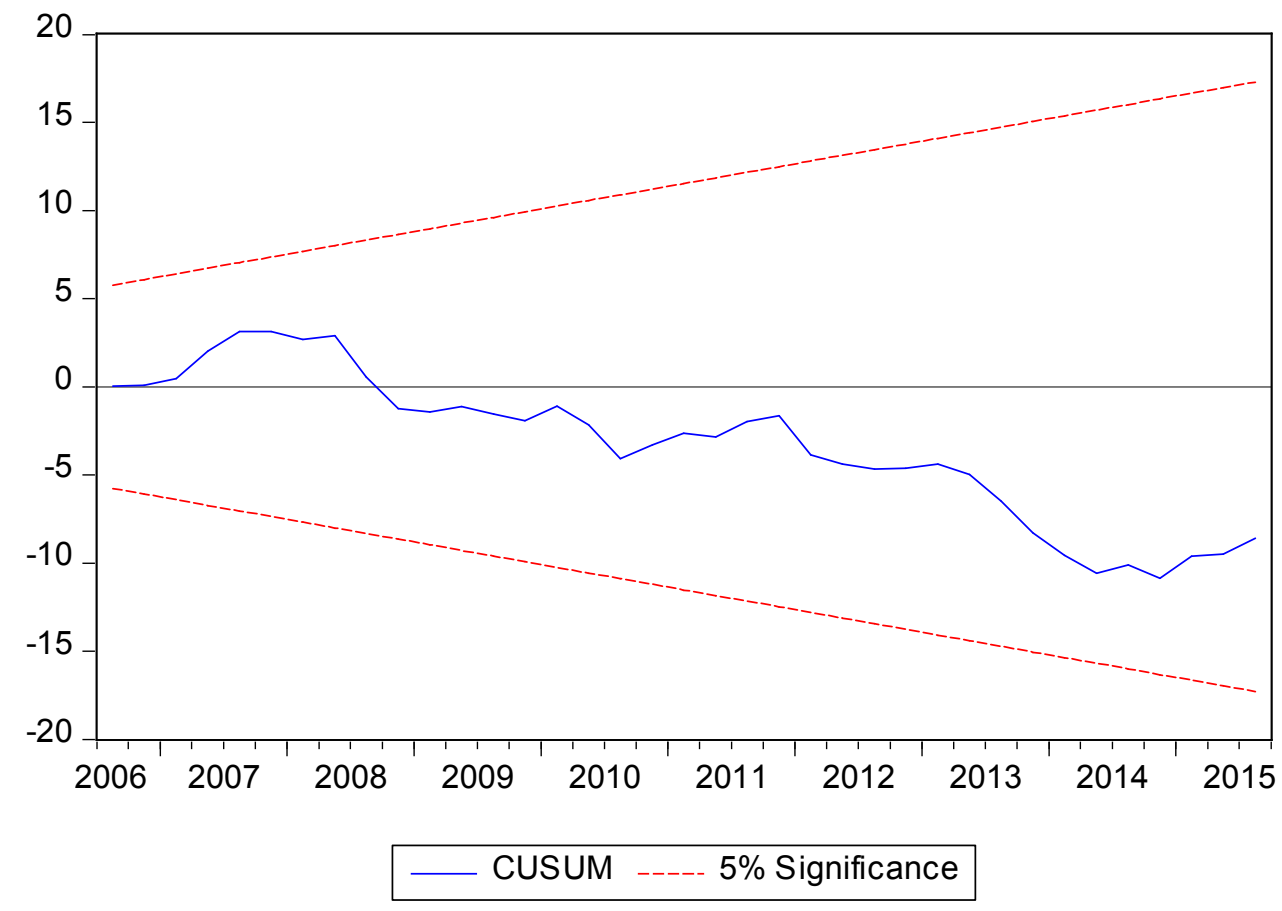


Gráfico 5.2: Controle de soma acumulada dos quadrados dos resíduos recursivos

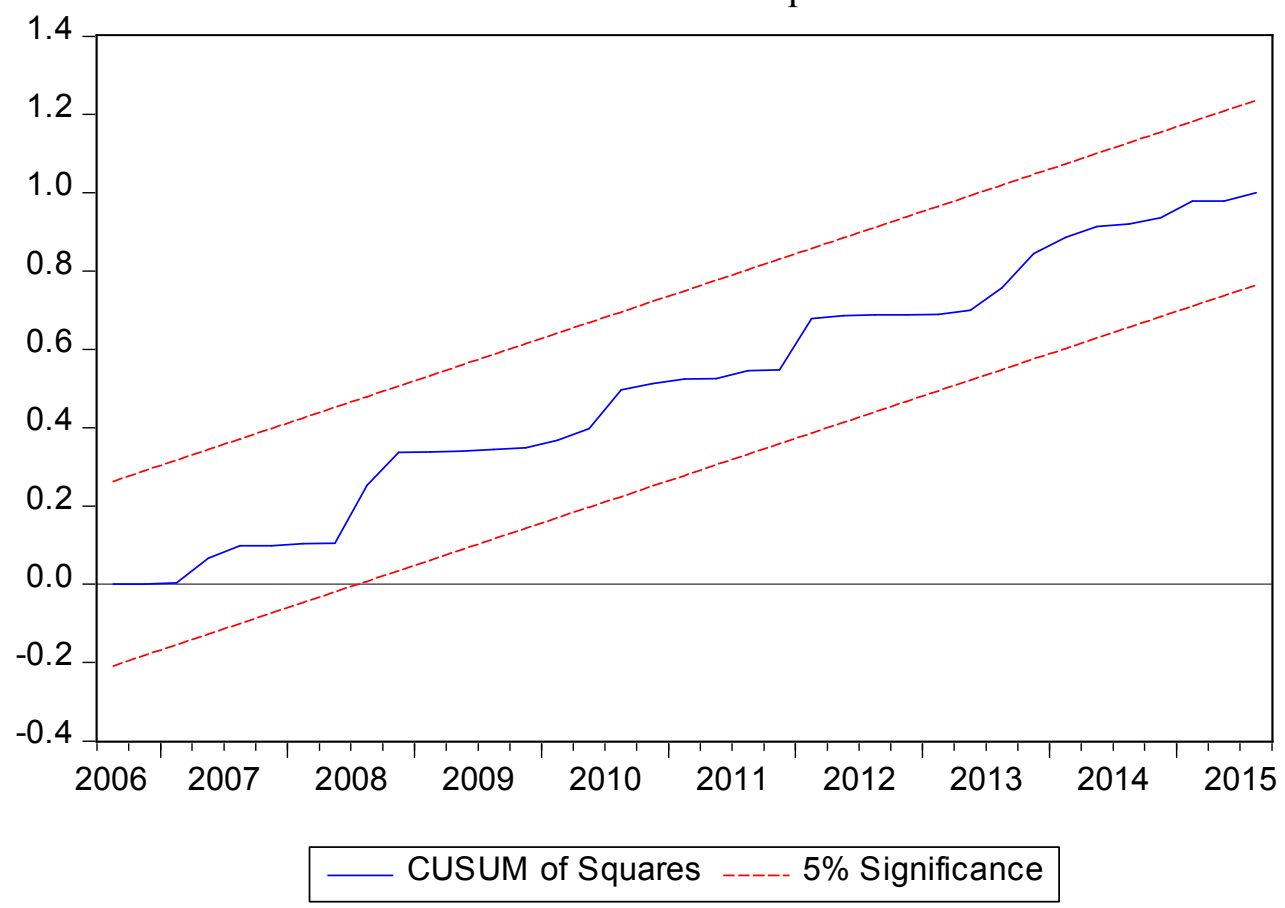

\subsection{Funções resposta-impulso}

Para extração das funções resposta-impulso e da decomposição da variância dos erros de previsão, foi estimado um VECM(5), cuja especificação é dada por:

$$
\Delta \mathrm{z}_{\mathrm{t}}=\alpha_{0}+\Pi \mathrm{z}_{\mathrm{t}-1}+\sum_{i=1}^{5} \Gamma_{\mathrm{i}} \Delta \mathrm{z}_{\mathrm{t}-\mathrm{i}}+\varepsilon_{\mathrm{t}}
$$

$\operatorname{Com} z_{t}=\left[\pi_{t}, i_{t}, c_{t}, h_{t}, e_{t}\right]^{\prime}$. Essa especificação, comparativamente ao ECM disposto em (4.7), exclui as expectativas para a inflação do conjunto de variáveis utilizadas na estimação do modelo. Em particular, tal exclusão proporcionou estabilidade estrutural ao sistema, i.e., que o inverso das raízes do polinômio característico fosse, em módulo, inferior a um.

A figura 5.1 ilustra a resposta das variáveis a um choque de magnitude igual a um desvio-padrão no volume de crédito concedido pelo sistema financeiro. 
Figura 5.1: Respostas a choques de um desvio padrão na variável crédito (FRIG)
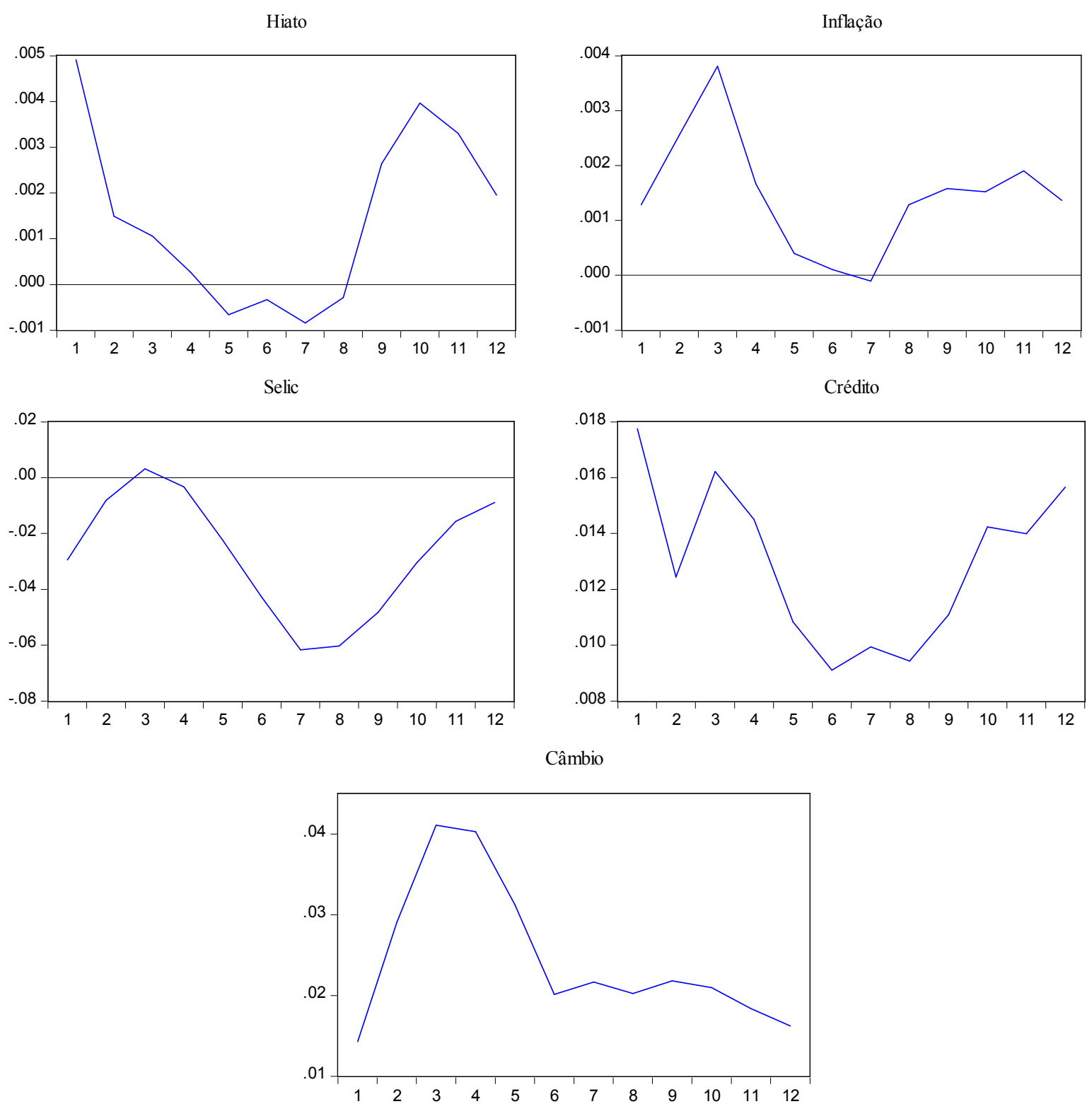

A perturbação no crédito possibilita um aumento do nível de despesas de firmas e famílias, estimulando a demanda agregada e elevando o hiato do produto. Combinados, tais fatores pressionam a o nível geral de preços da economia, de modo que o resultado final do processo é inflacionário, conforme gráfico que exibe a resposta do IPCA ao choque de crédito: a inflação atinge seu pico no terceiro trimestre após o movimento creditício, retrocedendo para o nível anterior ao choque até o sexto trimestre, para voltar a crescer e estabilizar-se em um patamar mais elevado - em comparação ao nível inicial de preços - dois anos depois do choque. 
Embora presente tal efeito inflacionário, em nenhum momento a política monetária aqui representada pela taxa Selic - parece atuar para reverter o processo. De fato, após uma queda no princípio, a taxa básica de juros retorna para seu patamar inicial cerca de três trimestres após o choque, para novamente retroceder, exibindo, assim, uma trajetória senoidal que atinge seu máximo no nível de juros anterior ao aumento no crédito. O fenômeno reforça a percepção de que a Selic, com o advento da Nova Matriz Macroeconômica, ter-se-ia convertido em objetivo (em contraposição a instrumento) de política monetária e, portanto, não responderia, com a tempestividade e magnitude necessárias, a eventuais pressões inflacionárias mapeadas pela autoridade monetária. De fato, quando iniciou o movimento de redução da Selic, em 2011, o próprio Banco Central previa inflação atingindo o teto da meta ao final daquele exercício, com uma probabilidade estimada em $45 \%$ de que o limite superior do intervalo fosse ultrapassado (BACEN, 2011). Referida percepção ganha ainda mais força quando se observa a resposta da Selic a um choque análogo tomando-se, porém, o período anterior à nova matriz, isto é, restringindo-se a amostra a observações entre 2000.2 e 2011.2: nesse período, a simulação retorna uma clara e positiva reação dos juros básicos em um cenário de elevação do crédito, conforme figura 5.2:

Figura 5.2: FRIG da Selic e câmbio a choques de um desvio padrão na variável crédito

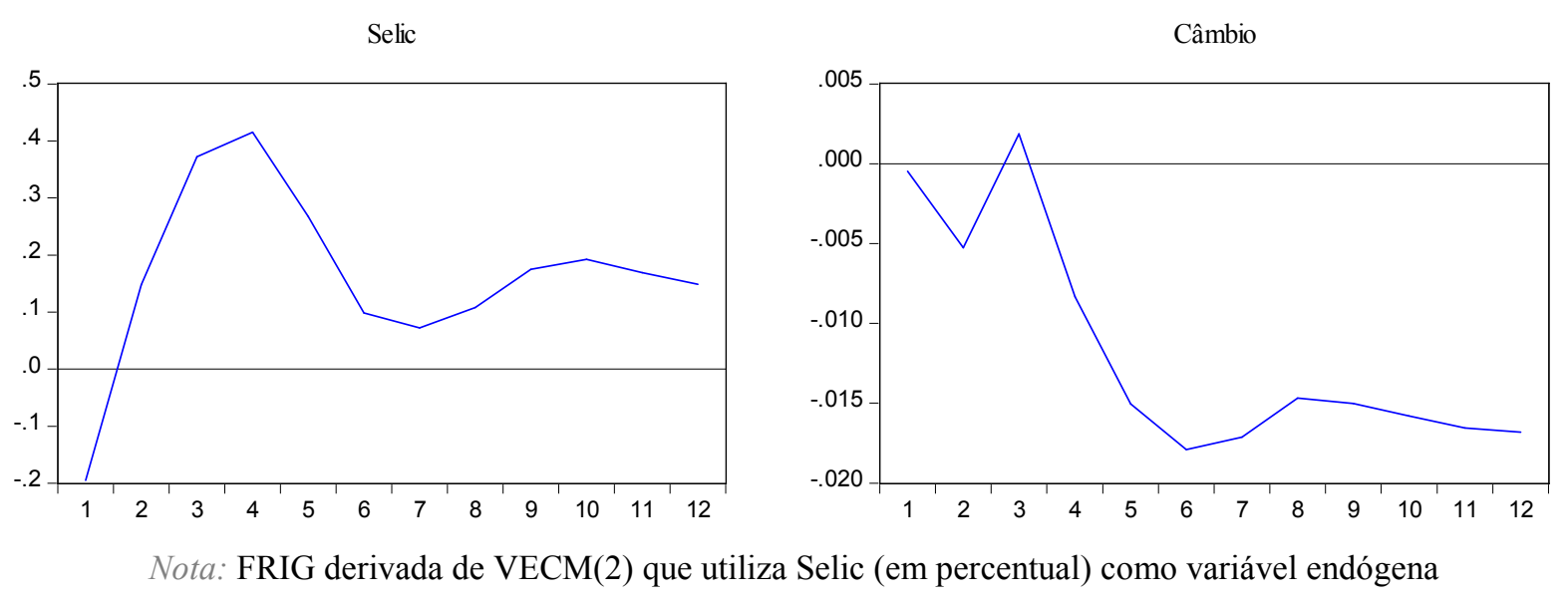

A figura 5.2 exibe, ainda, a FRIG da variável câmbio a um choque no volume crédito, tomando-se o período anterior à nova matriz macroeconômica. Também aqui nota-se movimento inverso ao observado na figura 5.1, que considera toda a amostra (de 1999 a 2015). Em resumo, até 2011 as variáveis Selic e câmbio respondem ao choque conforme previsto pela teoria econômica tradicional: i) a política monetária atua para neutralizar o efeito inflacionário da expansão creditícia; ii) o aumento dos juros de curto prazo estimula a entrada de capital estrangeiro no país, acarretando a apreciação cambial exibida em 5.2 (MUNDELL, 
1963). Após 2011, contudo, dada a resposta reticente - e mesmo negativa - da Selic a uma elevação no volume crédito, observa-se a depreciação cambial explicitada em 5.1, ilustrando um dos efeitos da política econômica consistente na Nova Matriz, como acima argumentado.

Por fim, consoante figura 5.3 adiante, o crédito reage negativamente a uma elevação na taxa básica de juros da economia - conforme previsto, a restrição monetária provoca o consequente aumento nos custos de endividamento cobrados de firmas e famílias, reduzindo consumo, investimento e PIB efetivo, nos termos do antecipado pelo tradicional canal de demanda. A redução na demanda agregada desestimula a procura por crédito, recrudescendo os efeitos do choque. Do mesmo modo, uma desvalorização da moeda doméstica reduz o nível de crédito concedido pelas instituições financeiras: o encarecimento do custo de captação inibe a oferta, por parte dos bancos, e, de outro lado, reduz a demanda oriunda de firmas que, embora preponderantemente aufiram receitas em reais, poderiam buscar financiamento em moeda estrangeira. Ambos os movimentos ocorrem consoante descrito pela teoria do canal do crédito, combinados os efeitos do banking lending e do balance-sheet channels.

Figura 5.3: Respostas do crédito a choques de um desvio padrão nas variáveis (FRIG):

Hiato

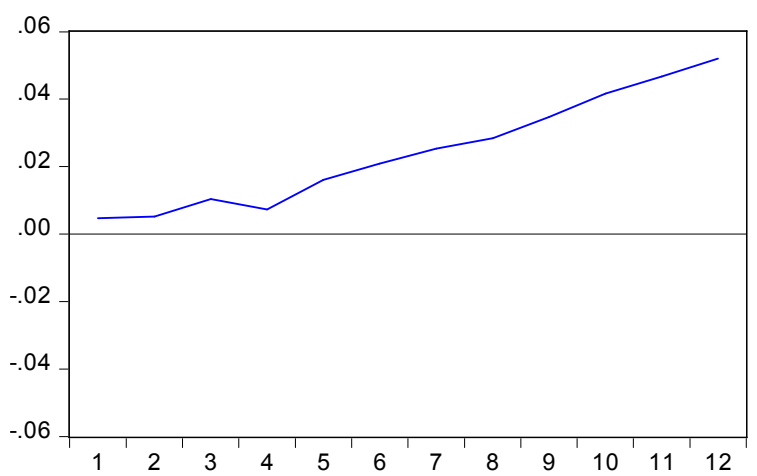

Selic

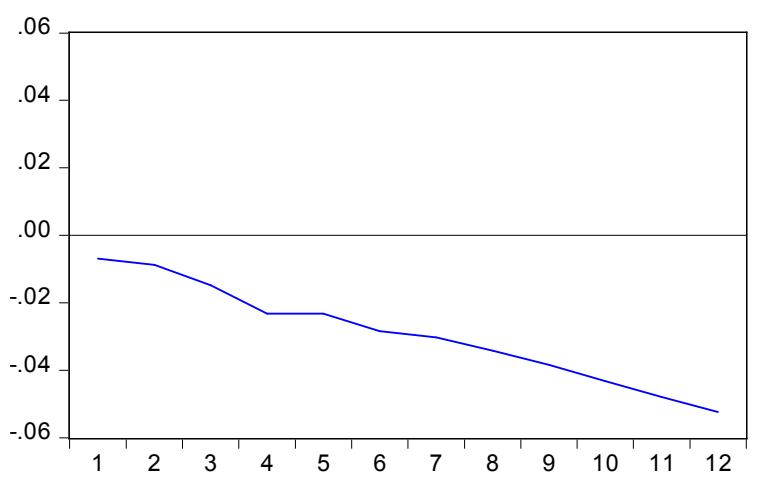

Inflação

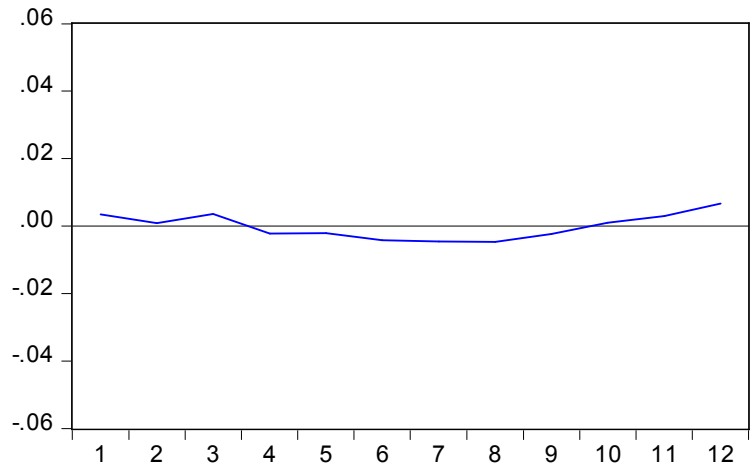

Câmbio

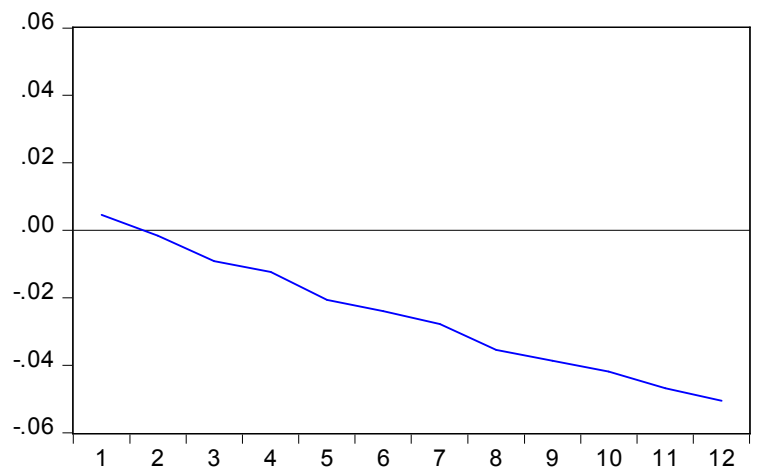




\subsection{Decomposição da variância dos erros de previsão}

A tabela 5.5 exibe os resultados da decomposição da variância do erro de previsão das variáveis utilizadas para estimação do VEC, utilizando-se a DVEPG. De acordo com a tabela, nota-se que, no curto prazo, a par do efeito dominante devido a choques na própria variável (79\%), secundado pela importância relativa de movimentos no índice de preços (13\%), perturbações no volume de crédito explicam cerca de 5,5\% do erro de previsão do hiato do produto no trimestre imediatamente posterior ao choque. Em seguida aparecem Selic e câmbio, contribuindo com percentuais bem mais modestos: aproximadamente, $1,5 \%$ e $0,9 \%$, nesta ordem. O resultado novamente sugere que perturbações no crédito afetam as decisões de gasto de firmas e famílias no curto prazo, confirmando a evidência obtida a partir da estimação das funções impulso-resposta e coadunando-se com as hipóteses albergadas pela teoria do credit channel.

A decomposição da variância da inflação, por seu turno, exibe um efeito ainda mais relevante de choques no crédito: após um pico de 14,7\% observado 12 meses após o choque, movimentos no saldo de crédito concedido pelo sistema financeiro explicam 11,6\% do erro de previsão da variância da inflação no horizonte de doze trimestres; choques na própria inflação respondem por 20,8\% e perturbações nos preços internacionais convertidos em moeda doméstica, por $50,4 \%$. Novamente, ratifica-se o potencial inflacionário inerente a choques de crédito, conforme discutido a partir dos resultados obtidos mediante a aplicação do modelo irrestrito de correção de erros (UECM).

No que concerne à reação do crédito diante de perturbações no sistema, extrai-se da tabela que movimentos na Selic são relevantes e representam cerca de $35 \%$ da variância do erro de previsão no horizonte de três anos após o choque, chegando a atingir quase $40 \%$ após seis trimestres. Em segundo lugar, o câmbio contribui com 30,9\%, seguido pelo hiato, com aproximadamente $28 \%$.

Tabela 5.5 - Decomposição da variância do erro de previsão

\begin{tabular}{lccccc}
\hline $\begin{array}{l}\text { Hiato } \\
\text { Período }\end{array}$ & Hiato & Inflação & Selic & Crédito & Câmbio \\
\hline 1 & 0,79 & 0,12 & 0,01 & 0,05 & 0,00 \\
2 & 0,74 & 0,17 & 0,01 & 0,02 & 0,03 \\
3 & 0,70 & 0,18 & 0,01 & 0,02 & 0,06 \\
4 & 0,65 & 0,18 & 0,03 & 0,01 & 0,10 \\
5 & 0,69 & 0,16 & 0,02 & 0,01 & 0,09 \\
6 & 0,71 & 0,15 & 0,02 & 0,00 & 0,09 \\
7 & 0,70 & 0,15 & 0,02 & 0,00 & 0,10 \\
\hline
\end{tabular}




\begin{tabular}{|c|c|c|c|c|c|}
\hline $\begin{array}{l}\text { Hiato } \\
\text { Período }\end{array}$ & Hiato & Inflação & Selic & Crédito & Câmbio \\
\hline 8 & 0,68 & 0,15 & 0,03 & 0,00 & 0,12 \\
\hline 9 & 0,69 & 0,17 & 0,02 & 0,00 & 0,10 \\
\hline 10 & 0,69 & 0,18 & 0,02 & 0,00 & 0,09 \\
\hline 11 & 0,68 & 0,19 & 0,02 & 0,00 & 0,09 \\
\hline 12 & 0,67 & 0,20 & 0,02 & 0,00 & 0,09 \\
\hline \multicolumn{6}{|l|}{ Inflação } \\
\hline Período & Hiato & Inflação & Selic & Crédito & Câmbio \\
\hline 1 & 0,11 & 0,73 & 0,04 & 0,02 & 0,07 \\
\hline 2 & 0,07 & 0,52 & 0,03 & 0,06 & 0,30 \\
\hline 3 & 0,05 & 0,38 & 0,02 & 0,13 & 0,39 \\
\hline 4 & 0,05 & 0,36 & 0,02 & 0,14 & 0,40 \\
\hline 5 & 0,08 & 0,35 & 0,03 & 0,14 & 0,38 \\
\hline 6 & 0,09 & 0,34 & 0,03 & 0,13 & 0,39 \\
\hline 7 & 0,08 & 0,31 & 0,04 & 0,12 & 0,43 \\
\hline 8 & 0,08 & 0,28 & 0,04 & 0,11 & 0,46 \\
\hline 9 & 0,10 & 0,25 & 0,04 & 0,11 & 0,47 \\
\hline 10 & 0,11 & 0,23 & 0,04 & 0,11 & 0,47 \\
\hline 11 & 0,11 & 0,22 & 0,04 & 0,12 & 0,49 \\
\hline 12 & 0,12 & 0,20 & 0,04 & 0,11 & 0,50 \\
\hline \multicolumn{6}{|l|}{ Crédito } \\
\hline Período & Hiato & Inflação & Selic & Crédito & Câmbio \\
\hline 1 & 0,05 & 0,02 & 0,11 & 0,75 & 0,04 \\
\hline 2 & 0,07 & 0,01 & 0,18 & 0,69 & 0,03 \\
\hline 3 & 0,11 & 0,01 & 0,25 & 0,53 & 0,07 \\
\hline 4 & 0,08 & 0,01 & 0,37 & 0,40 & 0,11 \\
\hline 5 & 0,12 & 0,00 & 0,38 & 0,28 & 0,18 \\
\hline 6 & 0,16 & 0,00 & 0,39 & 0,20 & 0,22 \\
\hline 7 & 0,19 & 0,00 & 0,39 & 0,15 & 0,25 \\
\hline 8 & 0,20 & 0,00 & 0,37 & 0,11 & 0,28 \\
\hline 9 & 0,22 & 0,00 & 0,36 & 0,09 & 0,30 \\
\hline 10 & 0,24 & 0,00 & 0,36 & 0,07 & 0,30 \\
\hline 11 & 0,26 & 0,00 & 0,35 & 0,06 & 0,31 \\
\hline 12 & 0,27 & 0,00 & 0,34 & 0,05 & 0,30 \\
\hline
\end{tabular}

Nota: Valores obtidos a partir de (4.14), utilizando-se os dados da FRIG expostos na tabela A.5. 


\section{CONSIDERAÇÕES FINAIS}

Diante da escolha governamental no sentido de alçar a expansão do crédito à condição de pilar de sustentação da estratégia de crescimento econômico do país, esta pesquisa buscou avaliar os eventuais impactos daí decorrentes sobre as variações do nível de preços medido pelo IPCA. Utilizando-se de um modelo irrestrito de correção de erros (UECM), procurou-se verificar a existência e estimar a intensidade do relacionamento entre referidas variáveis, no curto e longo prazos, adicionando-se, como demais regressores, uma estimativa para o hiato do produto, a taxa básica de juros da economia, os preços internacionais convertidos em moeda doméstica e as expectativas sobre a inflação. Recorreu-se, também, à análise de funções resposta-impulso e da decomposição da variância dos erros de previsão, derivadas de um modelo vetorial de correção de erros (VECM), visando a descrever a dinâmica de curto prazo e mensurar a influência do crédito sobre a inflação.

Após a realização de testes que demonstraram a validade e consistência dos modelos especificados, concluiu-se que, no curto prazo, a perturbação no crédito possibilita um aumento do nível de despesas de firmas e famílias, estimulando a demanda agregada e elevando o hiato do produto; por conseguinte, elevações no volume de crédito concedido pelo sistema financeiro têm impacto positivo e significante sobre os movimentos no nível de preços. No mesmo horizonte, e analogamente, as expectativas para inflação também se mostraram relevantes, confirmando sua importância sobre a formação de preços no curto prazo.

No longo prazo, as evidências obtidas são consistentes com as hipóteses e apontam para um efeito não desprezível da expansão do crédito sobre a inflação, isto é, um aumento no nível de crédito agregado acarreta pressões inflacionárias. Especificamente, uma elevação de $1 \%$ no volume de crédito traduz-se em um impacto inflacionário de $0,39 \%$. Tal constatação confirma a hipótese de que a trajetória crescente do volume de crédito observada no País, nos últimos anos, tem o condão de desequilibrar a estrutura de preços e provocar inflação. Do mesmo modo, os preços internacionais convertidos em moeda doméstica ganham destaque na determinação da inflação, no equilíbrio: uma depreciação de $1 \%$ da moeda doméstica acarreta um aumento de $0,23 \%$ no índice de preços.

Os resultados obtidos alinham-se à teoria apresentada neste trabalho em revisão de literatura, conforme capítulo que cuidou do canal do crédito e de sua importância como mecanismo capaz de promover um relaxamento das restrições orçamentárias de firmas e famílias. Esta é a principal contribuição deste estudo, confirmando, para o Brasil, as 
conclusões já obtidas em relação a outros países, é dizer, o caráter inflacionário de excessos na política creditícia. Confirmam-se, ainda, as conclusões que Barbi (2014b) e Fonseca (2014) alcançaram por metodologias diversas da utilizada neste trabalho. Extrai-se, daí, epílogo inevitável: deve-se lançar olhar necessariamente mais parcimonioso sobre a estratégia do governo federal de incentivo ao crédito, mediante maciço uso de bancos públicos, dados os potenciais efeitos deletérios que abusos em referida orientação trazem ao equilíbrio macroeconômico no longo prazo.

Também corroborando a previsão teórica, o crédito reage negativamente a uma elevação na Selic, dado que a restrição monetária acarreta um aumento nos custos de endividamento de firmas e famílias - movimento explicado pelo balance sheet channel. A desvalorização da moeda doméstica, por seu turno, reduz o nível de crédito concedido pelas instituições financeiras, ilustrando o efeito predito pelo banking lending channel.

Constatou-se, ainda, como resultado adicional da pesquisa, que, no contexto das ações adotadas sob a égide da "Nova Matriz Macroeconômica", a taxa Selic não respondeu conforme seria esperado e em linha com o que se observou até 2011 - com a tempestividade e magnitude necessárias aos movimentos inflacionários provocados pela aceleração no volume de crédito ofertado na economia. $\mathrm{O}$ fenômeno reforça a percepção de que, com o advento da Nova Matriz, reduziu-se a autonomia operacional do Banco Central, tendo a taxa básica de juros da economia se convertido em objetivo de política econômica, em claro prejuízo à credibilidade do Bacen e à efetividade das ações de política monetária.

Considerando que modelos lineares como o adotado no presente estudo podem não capturar, adequadamente, as assimetrias eventualmente presentes ao longo dos ciclos econômicos, uma extensão natural desta pesquisa é a adoção de frameworks não lineares multivariados para averiguar as conclusões aqui apresentadas. Dado o expressivo crescimento no volume de crédito, bem como a mudança de orientação na política econômica ao longo do período, pode-se lançar mão da estratégia aplicada por Calza e Souza (2005) para testar a sensibilidade dos resultados em um modelo econométrico regime-dependente, com a estimação de determinado limiar crítico, a partir do qual se poderia examinar possível alteração no comportamento das variáveis de interesse.

Noutro aspecto, e também com vistas a aprimorar o conhecimento na área desta pesquisa, é oportuno o empreendimento de estudos com a utilização de microdados que, à semelhança do proposto por Bayoumi e Melander (2008), voltem-se a estimar o efeito dos movimentos no mercado de crédito (volume e spreads) de maneira desagregada sobre os diferentes setores da economia. 


\section{REFERÊNCIAS}

Akaike, H. Information theory and an extension of the maximum likelihood principle. In Petrov, B.N.; Csáki, F., 2nd International Symposium on Information Theory, Tsahkadsor, Armenia, USSR, sept. 2-8, 1971, p. 267-281.Budapest: Akadémiai Kiadó, 1973.

Akerlof, G. The market for lemons: quality uncertainty and the market mechanism. Quarterly Journal of Economics, aug. 1970, p. 488-500. 1970.

Akram, T.; Li, H. The Empirics of Long-Term US Interest Rates. Levy Economics Institute of Bard College. Working Paper Series n. 863. Mar. 2016.

Alter, A.; Schüler, Y. S. Credit Spread Interdependencies of European States and Banks during the Financial Crisis. University of Konstanz, Department of Economics. Working Paper Series 2011-24. 2011.

Alves, S. A. L.; Tombini, A. S. The recent Brazilian disinflation process and costs. Brasília: Banco Central do Brasil, Working Paper Series, n. 109, jun. 2006.

Araújo, E. C.; Oreiro, J. L. C.; Fonseca, M. R. R. Não-linearidade da política monetária brasileira no período de metas de inflação: uma análise com base em um modelo MSVaR. Instituto de Economia da Universidade Federal do Rio de Janeiro (UFRJ). Texto para discussão n. 02. Rio de Janeiro, 2015.

Araújo, V. L.; Gentil, D. L. Avanços, Recuos, Acertos e Erros: Uma Análise da Resposta da Política Econômica Brasileira à Crise Financeira Internacional. Instituto de Pesquisa Econômica Aplicada (Ipea). Texto para discussão 1602, Rio de Janeiro, mar. 2011.

Arfanuzzaman, Md. The Long-Run Dynamic Relationship between Broad Money Supply and the GDP of Bangladesh: A VECM Approach. Developing Country Studies, v.4, n.14, p. 167-178. 2014.

Arsène, M.F.; Guy-Paulin, D.D. An econometric analysis of the nexus between credit to the private sector, inflation and economic growth: case of Cameroon 1965 - 2010. Global Journal of Management and Business Research, v. 13, n.7, p. 41-53. 2013.

Avdjiev, S.; Zeng, Z. Credit Growth, Monetary Policy, and Economic Activity in a Three-Regime TVAR Model. Bank for International Settlements Working Papers, n. 449. Jun. 2014.

Averbug, A.; Giambiagi, F. (2000). A crise brasileira de 1998/1999: origens e conseqüências. Banco Nacional de Desenvolvimento Econômico e Social (BNDES). Textos para discussão, v. 77. Rio de Janeiro, maio 2000.

Banco Central do Brasil (Bacen). Histórico das Taxas de Juros. Disponível em: http://www.bcb.gov.br/?COPOMJUROS. Acesso em: 06 abr. 2016.

Indicadores Econômicos Consolidados. Disponível em:

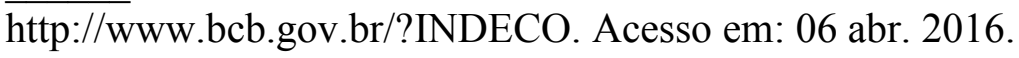


. Relatório de Inflação. Jun. 1999, Disponível em: http://www.bcb.gov.br/htms/relinf/port/1999/06/ri199906b4p.pdf. Acesso em: 08 abr. 2016.

Relatório de Inflação. Set. 2011, Disponível em: http://www.bcb.gov.br/htms/relinf/port/2011/09/ri201109c6p.pdf. Acesso em: 08 abr. 2016.

Bahmani-Oskooee, M.; Nasir, A. ARDL approach to test the productivity bias hypothesis. Review of Development Economics, v. 8, p. 483-488. 2004.

Barbi, F. C. Determinants of Credit Expansion in Brazil. São Paulo School of Economics (FGV). Mar. 17, 2014 (2014a).

Public Credit, Monetary Policy and Financial Stability. São Paulo School of Economics (Job Market Paper). Mar. 17, 2014 (2014b).

Barbosa, N.; Souza, J. A. P. A Inflexão do Governo Lula: Política Econômica, Crescimento e Distribuição de Renda. In Brasil: entre o Passado e o Futuro, E. Sader e M. A. Garcia (orgs.). São Paulo: Fundação Perseu Abramo e Editora Boitempo, 2010.

Bayoumi, T.; Melander, O. Credit Matters: Empirical Evidence on U.S. Macro-Financial Linkages. IMF Working Paper. July, 2008.

Belluzzo, L. G.; Coutinho, L. "Financeirização" da riqueza, inflação de ativos e decisões de gasto em economias abertas. Economia e sociedade, v. 11, p. 137-150, dez. 1998.

Ben-Kaabia, M.; Gil, J. M.; Chebbi, H. The effect of long-run identification on impulseresponse functions: An application to the relationship between macroeconomics and agriculture in Tunisia. Agricultural Economics Review, v. 3, n. 2, p.36-48. Aug., 2002.

Bernanke, B. S. Credit in the macroeconomy. Federal Reserve Bank of New York Quarterly Review, spring, 1992-93. 1992.

Bernanke, B.; Blinder, A. S. Credit, Money, and Aggregate Demand. NBER Working Paper Series, n. 2534. Mar., 1988.

The Federal Funds Rate and the Channels of Monetary Transmission. The American Economic Review, v. 82, n. 4, p. 901-921. Sept., 1992.

Bernanke, B.; Gertler, M. Agency Costs, Net Worth, and Business Fluctuations. The American Economic Review, v. 79, n. 1, p. 14-31. Mar. 1989.

Inside the Black Box: the credit channel of monetary policy transmission. NBER

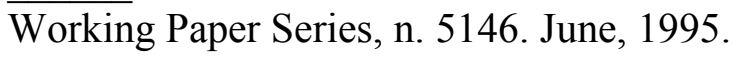

Bertola, G.; Disney, R.; Grant, C. The Economics of Consumer Credit. The MIT Press Cambridge, Massachusetts. London, England. 2006. 
Black, L. K.; Rosen, R. J. The Effect of Monetary Policy on the Availability of Credit: How the Credit Channel Works. Federal Reserve Bank of Chicago. Working Paper n. 200713 (revised). Mar. 2011.

Blanchard, O.; Dell'Ariccia, G.; Mauro, P. Rethinking Macroeconomic Policy. IMF Staff Position Note. Feb. 2010.

Blinder, A. S.; Stiglitz, J. E. Money, Credit Constraints and Economic Activity. NBER Working Paper Series, n. 1084. Mar. 1983.

Brasil. Banco Central do Brasil. Resolução 2.615, de 30 de junho de 1999. Fixa as metas para a inflação e seus respectivos intervalos de tolerância, bem como o índice de preços a que se aplicam, para os anos 2001, 2000 e 1999. Diário Oficial da República Federativa do Brasil. Brasília, 30 jun. 1999 (1999b).

Câmara de Comércio Exterior. Resolução 70, de 28 de setembro de 2012. Altera temporariamente a alíquota do Imposto de Importação ao amparo da Decisão no 39/11 do Conselho Mercado Comum do MERCOSUL - CMC. Diário Oficial da República Federativa do Brasil. Brasília, 01 out. 2012 (2012b).

Decreto 3.088, de 21 de junho de 1999. Estabelece a sistemática de "metas para a inflação" como diretriz para fixação do regime de política monetária e dá outras providências. Diário Oficial da República Federativa do Brasil. Brasília, 22 jun. 1999 (1999a).

Decreto 7.653, de 23 de dezembro de 2011. Autoriza o aumento do capital social do Banco Nacional de Desenvolvimento Econômico e Social - BNDES e da Caixa Econômica Federal - CEF, e dá outras providências. Diário Oficial da República Federativa do Brasil. Brasília, 26 dez. 2011.

Decreto 7.880, de 28 de dezembro de 2012. Autoriza o aumento de capital na Caixa Econômica Federal - CEF. Diário Oficial da República Federativa do Brasil. Brasília, 28 dez. 2012.

Lei Complementar n. 101, de 4 de maio de 2000. Estabelece normas de finanças públicas voltadas para a responsabilidade na gestão fiscal e da outras providencias. Diário Oficial da República Federativa do Brasil. Brasília, 5 mai. 2000. Disponível em: $<$ http://www.planalto.gov.br/ccivil_03/leis/LCP/Lcp101.htm> Acesso em: 6 abr. 2016.

Medida Provisória 470, de 13 de outubro de 2009. Constitui fonte adicional de recursos para ampliação de limites operacionais da Caixa Econômica Federal e dá outras providências. Diário Oficial da República Federativa do Brasil. Brasília, 14 out. 2009.

Medida Provisória 581, de 20 de setembro de 2012. Dispõe sobre o Fundo de Desenvolvimento do Centro-Oeste - FDCO; autoriza a União a conceder subvenção econômica às instituições financeiras oficiais federais, sob a forma de equalização de taxa de juros nas operações de crédito para investimentos no âmbito do FDCO; altera as Leis $\mathrm{n}^{\mathrm{o}} 7.827$, de 27 de setembro de 1989, e $\mathrm{n}^{\mathrm{o}} 10.177$, de 12 de janeiro de 2001, que tratam das operações com recursos dos Fundos Constitucionais de Financiamento do Norte, do Nordeste e do Centro-Oeste; constitui fonte adicional de recursos para ampliação de limites 
operacionais da Caixa Econômica Federal e do Banco do Brasil S.A., e dá outras providências. Diário Oficial da República Federativa do Brasil. Brasília, 21 set. 2012.

Medida Provisória 600, de 28 de dezembro de 2012. Altera a Lei $\mathrm{n}^{\circ} 12.409$, de 25 de maio de 2011; a Medida Provisória $n^{\circ}$ 581, de 20 de setembro de 2012, que dispõe sobre o Fundo de Desenvolvimento do Centro-Oeste - FDCO; constitui fonte adicional de recursos para ampliação de limites operacionais da Caixa Econômica Federal; altera as Leis no 12.462, de 4 de agosto de 2011, e $\mathrm{n}^{\mathrm{o}} 8.399$, de 7 de janeiro de 1992; altera a Medida Provisória $\mathrm{n}^{\mathrm{o}}$ 12.096, de 24 de novembro de 2009; altera a Lei $\mathrm{n}^{\mathrm{o}} 12.663$, de 5 de junho de 2012; e dá outras providências. Diário Oficial da República Federativa do Brasil. Brasília, 28 dez. 2012.

Medida Provisória 620, de 12 de junho de 2013. Altera a Lei $\mathrm{n}^{\circ} 12.793$, de 2 de abril de 2013, para dispor sobre o financiamento de bens de consumo duráveis a beneficiários do Programa Minha Casa Minha Vida, constitui fonte adicional de recursos para a Caixa Econômica Federal, altera a Lei $n^{\mathbf{0}} 12.741$, de 8 de dezembro de 2012, que dispõe sobre as medidas de esclarecimento ao consumidor, para prever prazo de aplicação das sanções previstas na Lei $\mathrm{n}^{\circ}$ 8.078, de 11 de setembro de 1990, e dá outras providências. Diário Oficial da República Federativa do Brasil. Brasília, 12 jun. 2013.

$2012(2012 a)$.

Ministério da Fazenda. Economia Brasileira em Perspectiva. 17. ed. Brasília, dez.

. Ministério da Fazenda. Economia Brasileira em Perspectiva. 18. ed. Brasília, mar. 2013.

Ministério da Fazenda e Ministério do Desenvolvimento, Indústria, e Comércio Exterior. Exposição de Motivos Interministerial no 4, de 21 de janeiro de 2009. Submete à consideração da Presidente da República proposta de edição de Medida Provisória, constituindo fonte adicional de recursos para permitir o financiamento de projetos de investimento por parte do Banco Nacional de Desenvolvimento Econômico e Social BNDES. Brasília, 2009.

Ministério do Planejamento, Orçamento e Gestão. Secretaria de Planejamento e Investimentos Estratégicos. Plano Plurianual 2012-2015, Mensagem Presidencial. Brasília, 2011. Disponível em http://planejamento.gov.br/secretarias/upload/arquivo/spi-1/ppa1/2012/mensagem_presidencial_ppa-2.pdf. Acesso em: 06 jul. 2015.

Tribunal de Contas da União. Acórdão 3.071/2012-TCU-Plenário. Relatório de Levantamento de Auditoria - Processo TC 022.684/2010-7. Unidade Técnica: Secretaria de Macroavaliação Governamental. Relator: Min. Aroldo Cedraz. Brasília, 14 de julho de 2012.

Bresser-Pereira, L. C. O Tripé, o Trilema e a Política Macroeconômica. In Dossiê da Crise IV: A Economia Brasileira na Encruzilhada, p. 10-18. Out. 2013.

Brooks, C. Introductory Econometrics for Finance. 2. ed. Cambridge: Cambridge University Press, 2008.

Brooks, P. K. The Bank Lending Channel of Monetary Transmission: Does It Work in Turkey? IMF Working Paper 07/272. 2007. 
Cakan, E.; Mona, K. Impact of Military Expenses on the US Economic Growth: A Cointegration Analysis by ARDL Bound Test. Department of Economics, The University of New Haven. Working Paper n. 1311. 2013.

Caldas, F. A. M. R. Análise Econômica do Especialista. In Dez Anos de Metas para a Inflação no Brasil - 1999-2009. Brasília: Banco Central do Brasil, 2011. p. 401-454.

Calza, A.; Souza, J. Output and Inflation Responses to Credit Shocks: Are There Threshold Effects in the Euro Area? European Central Bank. Working Paper Series, n. 481. Apr. 2005.

Campbell, J.; Mankiw, G. Permanent Income, Current Income, and Consumption. Journal of Business and Economic Statistics, 8, p. 265-279. 1990.

Carneiro, D. D. et al. Mecanismos não-lineares de repasse cambial para o IPCA. Revista de Economia e Administração, v. 3, n. 1, jan./mar. 2002.

Carneiro, D. D.; Salles, F. M.; Wu, T. Y. H. Juros, câmbio e as imperfeições do canal do crédito. Economia Aplicada, v. 10(1), p. 7-23. Jan./mar. 2006.

Caneiro, F. G.; Divino, J. A. C. A.; Rocha, C. H. Reconsiderando o efeito Fisher: uma análise de cointegração entre taxas de juros e inflação. Revista Nova Economia, v. 13, n. 1, p. 81-100, jan./jun. 2003.

Carrara, A. F; Correa, A. L. O Regime de Metas de Inflação no Brasil: Uma Análise Empírica do IPCA. Revista Economia Contemporânea, v. 16, n. 3, p. 441-462, set./dez. 2012.

Castro, N. J.; Brandão, R.; Dantas, G.; Rosental, R. O Processo de Reestruturação do Setor Elétrico Brasileiro e os Impactos da MP 579. In: Seminário Redução das Tarifas do Setor Elétrico Brasileiro. Rio de Janeiro, 2013.

Ciccarelli, M.; Maddaloni, A.; Peydró, J. L. Trusting the Bankers: A New Look at the Credit Channel of Monetary Policy. European Central Bank. Working Paper Series, n. 1228. Jul. 2010

Cooley, T. F.; LeRoy, S. F. Atheoretical Macroeconometrics: A critique. Journal of Monetary Econometrics, v. 16, p. 283-308.1985.

Costa, F. N. Atuação anticíclica dos bancos públicos brasileiros. Instituto de Economia da Universidade Estadual de Campinas (Unicamp). Texto para Discussão n. 258. Campinas, set. 2015.

Davidson, J. E. H.; Hendry, D. F.; Srba, F.; Yeo, S. Econometric modelling of the aggregate time-series relationship between consumers' expenditure and income in the United Kingdom. Economic Journal, v. 88, n. 352, p. 661-692. Dec. 1978.

Deaton, A. Understanding Consumption. Oxford: Oxford University Press.1992. 
Dees, S.; Holly, S.; Pesaran, M. H.; Smith, L. V. Long Run Macroeconomic Relations in the Global Economy. European Central Bank. Working Paper Series n. 750. May 2007.

Dritsakis, N. Demand for Money in Hungary: An ARDL Approach. Review of Economics and Finance, n. 5. 2011.

Eslamloueyan, K.; Darvishi, A. Credit Expansion and Inflation in Iran: An Unrestricted Error Correction Model. Iranian Economic Review, v. 12, n. 19, p. 105-126. 2007.

European Central Bank. Introductory statement by Mr. Jean-Claude Trichet, President of the European Central Bank, at the European Parliament. Brussels, 14 Sep. 2005.

Fazzari, S.; Hubbard, G.; Petersen, B. Financing Constraints and Corporate Investment. Brookings Papers on Economic Activity, v. 1, p. 141-195. 1988.

Ferreira, A. B.; Jayme Junior, F. G. Metas de Inflação e Vulnerabilidade Externa no Brasil. In XXXIII Encontro Nacional de Economia da ANPEC - Anais. Natal: ANPEC, 2005

Fonseca, M. G. S. Credit Shocks and Monetary Policy in Brazil: A Structural FAVAR Approach. Tese (Doutorado em Economia). Escola de Economia de São Paulo (FGV). São Paulo, 2014.

Fraga Neto, A. Dez Anos de Metas para a Inflação. In Dez Anos de Metas para a Inflação no Brasil - 1999-2009. Brasília: Banco Central do Brasil, 2011. p. 24-34.

Friedman, M. The role of monetary policy. The American Economic Review, v. LVIII, n. 1, mar. 1968.

Friedman, B. M.; Kuttner, K. N. Economic Activity and the Short-term Credit Markets: An Analysis of Prices and Quantities. Brookings Papers on Economic Activity, v. 2, p. 193283. 1993

Fuerst, T. Liquidity, loanable funds, and real activity. Journal of Monetary Economics, february 1992. p. 3-24. 1992.

Gilchrist, S. G.; Zakrajsek, E. The Importance of Credit for Macroeconomic Activity: Identification Through Heterogeneity. Conference Series, Federal Reserve Bank of Boston, v. 39, p. 129-173. 1995.

Gjanci, G.; Cërava, A. An empirical analysis of the trade balance in post-communist Albania. Review of Applied Socio-Economic Research, v. 7, n. 1, p. 33-42. 2014.

Gomes, F. A. R. Consumo no Brasil: Comportamento Otimizador, Restrição de Crédito ou Miopia? Revista Brasileira de Economia, v. 64, n. 3, p. 261-275. Jul./set. 2010.

Gomes, F. A. R.; PAZ, L. S. Consumption in South America: Myopia or Liquidity Constraints? Economia Aplicada, v. 14, n. 2, p. 129-145. 2010.

Gonçalves, C. E. Too Tight and Too Loose: Policy in Brazil in the last decade. Working paper. Set. 2015. Disponível em: http://www.joserobertoafonso.ecn.br/biblioteca- 
virtual/item/download/2648_d741be579319910d7bb3672b76a2375a.html. Acesso em: 07 abr. 2016.

Harris, R. I. D. Using Cointegration Analysis in Econometric Modelling. Harlow: Prentice Hall, 1995.

Hendricks, T. W.; Kempa, B. Monetary policy and the credit channel, broad and narrow. Eastern Economic Journal, v. 37, p. 403-416. Summer 2011.

Holland, M. Transição para a nova matriz macroeconômica afetou o PIB. Valor Econômico. Brasília, 17 dez. 2012.

Instituto Brasileiro de Geografia e Estatística (IBGE). Sistema nacional de índices de preços ao consumidor. Disponível em: http://www.ibge.gov.br/home/estatistica/indicadores/precos/ inpc_ipca/ipca-inpc_201505_1.shtm. Acesso em: 02 jul. 2015.

Jensen, M.; Meckling, W. Theory of the firm managerial behavior, agency costs, and ownership structure. Journal of Financial Economics, p. 305-360. Oct. 1976.

Johansen, S. Likelihood-Based Inference in Cointegrated Vector Autorregressive Models. Oxford: Oxford University Press, 1995.

Kaliontzakis, M. The curious case of Greece: The impact of fiscal policy shocks on key macroeconomic variables. A VAR based approach. Master's Theses. Paper 134. 2015.

Kashyap, A. K.; Stein, J. C. Monetary Policy and Bank Lending. In Monetary Policy, p. 221-261. The University of Chicago Press. 1994.

What Do A Million Observations on Banks Say About the Transmission of Monetary Policy? American Economic Review, v. 90, n. 3, p. 407-428. Jun. 2000.

Keong, C. C.; Yusop, Z.; Sen, V. L. K. Export-Led Growth Hypothesis in Malaysia: An Investigation Using Bounds Test. Sunway Academic Journal. n. 2, p. 13-22. 2005.

Koop, G.; Pesaran, M. H.; Potter, S. M. Impulse response analysis in nonlinear multivariate models. Journal of Econometrics, v. 74, p. 119-47. 1996.

Korkmaz, S. Impact of Bank Credits on Economic Growth and Inflation. Journal of Applied Finance \& Banking, v. 5, n. 1/2015, p. 57-69. Scienpress Ltd. 2015.

Kwiatkowski, D.; Phillips, P. C. B.; Schmidt, P.; Shin, Y. Testing the Null Hypothesis of Stationarity against the Alternative of a Unit Root. Journal of Econometrics, v. 54, p. 159178. 1992.

Lanne, M.; Nyberg, H. Generalized forecast error variance decomposition for linear and nonlinear multivariate models. School of Economics and Management, University of Aarhus. CREATES Research Papers 2014-17. May 2014. 
Lima, I. S.; Ferreira, D. Q. G. A Participação Estatal no Sistema Bancário Brasileiro: Uma Análise Do Período 1996-2006. IPEA: Planejamento e Políticas Públicas. n. 39, jul.dez. 2012.

Ludvigson, S. Consumption and Credit: A Model of Time-Varying Liquidity Constraints. The Review of Economics and Statistics, v. 81(3), p. 434-447. Aug. 1999.

Lütkepohl, H. New Introduction to Multiple Time Series Analysis. Berlin: Springer, 2005.

Lütkepohl, H.; Krätzig, M. Applied Time Series Econometrics. Cambridge: Cambridge University Press, 2004.

MacKinnon, J. G. Numerical distribution functions for unit root and cointegration tests. Journal of Applied Econometrics, v. 11, p. 601-618. 1996.

Mantega, G. O primeiro ano da nova matriz econômica. Valor Econômico. Brasília, 19 dez. 2012.

Mello, G. S. Regimes macroeconômicos e o Brasil pós-crise. Revista Política Social e Desenvolvimento, ano 3, p. 16-23. Mar. 2015.

Mendonça, H. F.; Silva, R. T. Administração da dívida pública sob um regime de metas para inflação: evidências para o caso brasileiro. Economia Aplicada, v. 12, n. 4, p. 635657. Out./dez. 2008.

Minella, A; Souza-Sobrinho, N. F. Canais Monetários no Brasil sob a Ótica de um Modelo Semiestrutural. In Dez Anos de Metas para a Inflação no Brasil- 1999-2009. Brasília: Banco Central do Brasil, 2011. p. 35-93.

Mishkin, F. S. Is the Fisher effect for real? A reexamination of the relationship between inflation and interest rates. NBER Working Paper Series, n. 3632. Feb. 1991.

. Symposium on the Monetary Transmission Mechanism. Journal of Economic Perspectives, v. 9, n. 4, p. 3-10. Fall 1995.

The economics of money, banking and financial markets. 9. ed. The AddisonWesley Series in economics. Boston: Pearson Education, Inc, 2009.

Modenesi, A. M.; Modenesi, R. L.; Martins, N. M.; Araújo, P. F. R. Reestruturando o Arcabouço de Política Econômica em um Contexto de Crise: em direção a uma nova convenção? Instituto de Economia da Universidade Federal do Rio de Janeiro (UFRJ). Texto para discussão n. 12. Rio de Janeiro, 2013.

Modigliani, F. The Monetary Mechanism and Its Interaction with Real Phenomena. The State of Monetary Economics. National Bureau Committee for Economic Research. p. 79107. 1965.

Modigliani, F.; Miller, M. H. The cost of capital, corporation finance and the theory of investment. The American Economic Review, v. XLVIII, n. 3, june, 1958. 
Moinescu, B. G. Credit Flow, Output Gap and Inflation: Nominal Convergence Challenges for the EU New Members States. Journal of Applied Quantitative Methods, v. 7, n. 4. Winter, 2012.

Morais, L; Saad-Filho, A. Da economia política à política econômica: o novodesenvolvimentismo e o governo Lula. Revista de Economia Política, v. 31, n. 4 (124), p. 507-527, out./dez. 2011.

Muinhos, M. K.; Alves, S. A. L. Medium-size macroeconomic model for the Brazilian economy. Brasília: Banco Central do Brasil, Working Paper Series, n. 64. 2003.

Mundell, R. A. Capital Mobility and Stabilization Policy under Fixed and Flexible Exchange Rates. The Canadian Journal of Economics and Political Science, v. 29, n. 4, p. 475-485. Nov. 1963.

Nassif, A. Dilma 2.0: dará certo a continuidade do tripé da política macroeconômica? Revista Política Social e Desenvolvimento, ano 3, p. 6-27. Abr. 2015.

Nowak, H. A. Z.; Bista, N. B. Macroeconomic implications of fiscal deficit in Nepal. Journal of Management and Development Economics, v. 3, n. 1, apr., 2014.

Oliner, S. D.; Rudebusch, G. D. Is There a Broad Credit Channel for Monetary Policy? Federal Reserve Bank of San Francisco Economic Review, n. 1. 1996.

Oliveira, F. N.; Andrade Neto, R. M.A Relevância do Canal de Empréstimos Bancários no Brasil. Revista Brasileira de Finanças, v. 6, n. 3, p. 357-409. 2008

Oreiro, J. L. C. Muito além do tripé: proposta de um novo regime de política macroeconômica para dobrar a renda per capita em 20 anos. In: Seminário Indústria e Desenvolvimento Produtivo do Brasil. São Paulo, 2014.

Do Tripé Macroeconômico ao Fracasso da Nova Matriz: A Evolução do Regime de Política Macroeconômica no Brasil (1999-2014). Revista Politika. No prelo, 2015.

Brasil: Do "Espetáculo do Crescimento" a Estagnação Secular? Disponível em http://joseluisoreiro.com.br/site/link/2efc4d314e27790611ac00749a9a33ba4e2f032c.pdf. Acesso em: 06 abr. 2015. (2015)

Ozcelbi, O. The Role of Interest Rates and Credits in Explaining Output Variations: Empirical Evidence from Turkey and the Euro Area. Privredna kretanja i ekonomska politika, v. 133, p. 47-77. 2012.

Pesaran, M. H.; Shin. Y. Generalized Impulse Response Analysis in Linear Multivariate Models. Economic Letters, v. 58, n. 1, p. 17-29. 1998.

Long Run Structural Modelling. Edinburgh School of Economics, Discussion Paper Series, n. 44. Apr., 1999.

Pesaran, H.; Shin, Y.; Smith, R. J. Bounds Testing Approaches to the Analysis of Level Relationship. Journal of Applied Econometrics 16, p. 289-326. 2001. 
Poole, W. Credit Veils and Credit Realities. Federal Reserve Bank of New York Quarterly Review, p. 83-85. Spring, 1992-93.

Poon, Wai-Ching. A monetary policy rule: The augmented Monetary Conditions Index for Philippines using UECM and bounds tests. Monash University. Department of Economics, Discussion paper 04/10. 2010

Roarelli. M. L. M.; Ornelas Neto, J.; Brown, R. Análise das recentes operações entre o Tesouro, o BNDES, a CEF e o Fundo Soberano e seu impacto sobre as contas públicas a “Contabilidade Criativa". Senado Federal. Orçamento Público em discussão, v. 11. 2013.

Romer, D. Advanced Macroeconomics. 4th. ed. New York: McGraw-Hill, 2012.

Santin, R. R. M. Análise da Política de Crédito do BNDES em um Modelo DSGE. Dissertação (Mestrado em Economia). Escola de Economia de São Paulo (FGV). São Paulo, 2013.

Saxegaard, M. Excess Liquidity and Effectiveness of Monetary Policy: Evidence from Sub-Saharan Africa. IMF Working Paper 06/115. 2006.

Schwartzman, F. F. Estimativa de curva de Phillips para o Brasil com preços desagregados. Economia Aplicada, v. 10, n. 1, p. 137-155, jan./mar. 2006.

Sims, C. A. Interpreting the Macroeconomic Time Series Facts: The Effects of Monetary Policy. European Economic Review, v. 36, p. 975-1000. June, 1992.

Siqueira, M. S. Política Monetária e Inflação no Brasil: Uma Análise pela Função Impulso-Resposta Generalizada. Dissertação (Mestrado em Finanças e Economia Empresarial). Fundação Getúlio Vargas (FGV). Rio de Janeiro, 2007.

Soares, F. A. R. A Administração da Taxa de Câmbio no Plano Real e os Fundamentos Econômicos Brasileiros. Tese (Doutorado em Economia). Faculdade de Economia, Administração, Contabilidade e Ciência da Informação e Documentação da Universidade de Brasília. Brasília, jun. 2006.

Souza-Sobrinho, N. F. Uma avaliação do canal do crédito no Brasil. Dissertação (Mestrado em Economia). Faculdade de Economia, Administração e Contabilidade da Universidade de São Paulo (USP). 2003.

Tang, T .C. Bank Lending and Inflation in Malaysia: Assessment from Unrestricted Error-Correction Models. Asian Economic Journal, v. 15, n. 3, p. 275-289. 2001.

Tornell, A.; Westermann, F. The Credit Channel in the Middle Income Countries. NBER Working Paper Series, n. 9355. Nov. 2002.

Walsh, C. E. Monetary Theory and Policy. 3. ed. Cambridge: The MIT Press, 2010.

Walsh, C. E.; e Wilcox, J. A. Bank credit and economic activity. Conference Series, Federal Reserve Bank of Boston. v. 39, p. 83-125. 1995. 
Yusof, R. M.; Usman, F. H. Islamic Home Financing and the Real Sectors in Malaysia: An ARDL Bound Testing Approach to Cointegration. International Journal of Economics, Management and Accounting, v. 23, n. 1, p. 79-107. 2015.

Zeldes, S. P. Consumption and Liquidity Constraints: An Empirical Investigation. Journal of Political Economy, v. 97, n. 2, p. 305-346. 1989. 


\section{APÊNDICE}

Tabela A.1 - Resultados dos testes de raiz unitária Augmented Dickey Fuller (ADF)

\begin{tabular}{lcccc}
\hline \multirow{2}{*}{ Variável } & \multicolumn{3}{c}{ nível } & \multicolumn{2}{c}{ primeira diferença } \\
\cline { 2 - 5 } & intercepto & tendência e intercepto & intercepto & tendência e intercepto \\
\hline$\pi$ & $-1.12(3)$ & $-2.33(3)$ & $-3.41(2)^{* *}$ & $-3.50(2)^{* *}$ \\
$\mathrm{i}$ & $-2.34(1)$ & $-3.38(1)^{*}$ & $-6.10(2)^{* * *}$ & $-6.07(2)^{* * *}$ \\
$\mathrm{c}$ & $0.37(1)$ & $-1.81(1)$ & $-2.49(3)$ & $-2.35(3)$ \\
$\mathrm{h}$ & $-1.04(1)$ & $-0.77(1)$ & $-4.94(0)^{* * *}$ & $-5.13(0)^{* * *}$ \\
$\mathrm{e}$ & $-1.14(1)$ & $-1.70(1)$ & $-5.39(0)^{* * *}$ & $-5.37(0)^{* * *}$ \\
$\mathrm{E}_{\mathrm{t}-1}\left(\pi_{\mathrm{t}}\right)$ & $-3.18(5)^{* *}$ & $-3.04(5)$ & $-4.18(4)^{* * *}$ & $-4.23(4)^{* * *}$ \\
\hline
\end{tabular}

Notas: Os algarismos entre parêntesis representam o número ótimo de lags, cuja seleção foi feita de maneira automática com base no Schwarz information criterion (número máximo de defasagens limitado a dez). Asteriscos $(*, * *, * * *)$ denotam rejeição da hipótese nula ao nível de $10 \%, 5 \%$ e $1 \%$, respectivamente, com valores críticos baseados em MacKinnon (1996).

Tabela A.2 - Resultados dos testes de raiz unitária Phillips-Perron (PP)

\begin{tabular}{lcccc}
\hline \multirow{2}{*}{ Variável } & \multicolumn{2}{c}{ nível } & \multicolumn{2}{c}{ primeira diferença } \\
\cline { 2 - 5 } & intercepto & tendência e intercepto & intercepto & tendência e intercepto \\
\hline$\pi$ & $-1.36(0)$ & $-1.83(1)$ & $-5.05(8)^{* * *}$ & $-5.02(9)^{* * *}$ \\
$\mathrm{i}$ & $-1.74(4)$ & $2.28(3)$ & $-4.45(14)^{* * *}$ & $-4.44(14)^{* * *}$ \\
$\mathrm{c}$ & $0.46(4)$ & $-2.17(4)$ & $-7.81(4)^{* * *}$ & $-7.80(4)^{* * *}$ \\
$\mathrm{~h}$ & $-0.26(1)$ & $0.63(0)$ & $-4.91(2)^{* * *}$ & $-5.10(2)^{* * *}$ \\
$\mathrm{e}$ & $-0.71(5)$ & $-1.22(4)$ & $-5.23(14)^{* * *}$ & $-5.19(14)^{* * *}$ \\
$\mathrm{E}_{\mathrm{t}-1}\left(\pi_{\mathrm{t}}\right)$ & $-4.89(9)^{* * *}$ & $-4.90(8)^{* * *}$ & $-17.86(20)^{* * *}$ & $-17.53(20)^{* * *}$ \\
\hline
\end{tabular}

Notas: Os algarismos entre parêntesis representam a largura de banda (bandwidth) ótima, cuja seleção foi feita de maneira automática com base no método de estimação espectral Newey-West usando kernel de Bartlett (1994). Asteriscos $\left({ }^{* *}\right)$ denotam rejeição da hipótese nula ao nível de $1 \%$, com valores críticos baseados em MacKinnon (1996).

Tabela A.3 - Resultados dos testes de raiz unitária Kwiatkowski-Phillips-Schmidt-Shin (KPSS)

\begin{tabular}{lcccc}
\hline \multirow{2}{*}{ Variável } & \multicolumn{2}{c}{ nível } & \multicolumn{2}{c}{ primeira diferença } \\
\cline { 2 - 5 } & intercepto & tendência e intercepto & intercepto & tendência e intercepto \\
\hline$\pi$ & $1.02(6)^{* * *}$ & $0.17(6)^{* *}$ & $0.25(2)$ & $0.15(1)^{* *}$ \\
$\mathrm{i}$ & $0.79(6)^{* * *}$ & $0.12(5)^{* *}$ & $0.11(5)$ & $0.08(5)$ \\
$\mathrm{c}$ & $1.02(6)^{* * *}$ & $0.15(6)^{* *}$ & $0.28(5)$ & $0.26(4)^{* * *}$ \\
$\mathrm{~h}$ & $0.14(5)$ & $0.14(5)^{* *}$ & $0.32(2)$ & $0.16(1)^{* *}$ \\
$\mathrm{e}$ & $0.43(6)^{*}$ & $0.12(6)^{*}$ & $0.19(6)$ & $0.18(6)^{* *}$ \\
$\mathrm{E}_{\mathrm{t}-1}\left(\pi_{\mathrm{t}}\right)$ & $0.26(4)$ & $0.15(4)^{* *}$ & $0.15(17)$ & $0.13(16)^{* *}$ \\
\hline
\end{tabular}

Notas: Os algarismos entre parêntesis representam a largura de banda (bandwidth) ótima, cuja seleção foi feita de maneira automática com base no método de estimação espectral Newey-West usando kernel de Bartlett (1994). Asteriscos $(*, * *, * * *)$ denotam rejeição da hipótese nula (estacionariedade) ao nível de $10 \%, 5 \%$ e $1 \%$, respectivamente, com valores críticos baseados em Kwiatkowski-Philips-Schmidt-Shin (1992). 
Tabela A.4 - VECM - Raízes do polinômio característico

\begin{tabular}{cc}
\hline Raiz & Módulo \\
\hline 1,00 & 1,00 \\
1,00 & 1,00 \\
1,00 & 1,00 \\
1,00 & 1,00 \\
$0,01+0,98 \mathrm{i}$ & 0,98 \\
$0,01-0,98 \mathrm{i}$ & 0,98 \\
$-0,98$ & 0,98 \\
0,95 & 0,95 \\
$0,82-0,46 \mathrm{i}$ & 0,94 \\
$0,82+0,46 \mathrm{i}$ & 0,94 \\
$0,59-0,65 \mathrm{i}$ & 0,88 \\
$0,59+0,65 \mathrm{i}$ & 0,88 \\
$-0,67+0,47 \mathrm{i}$ & 0,82 \\
$-0,67-0,47 \mathrm{i}$ & 0,82 \\
$-0,21-0,78 \mathrm{i}$ & 0,80 \\
$-0,21+0,78 \mathrm{i}$ & 0,80 \\
$0,21+0,77 \mathrm{i}$ & 0,80 \\
$0,21-0,77 \mathrm{i}$ & 0,80 \\
$-0,45-0,65 \mathrm{i}$ & 0,79 \\
$-0,45+0,65 \mathrm{i}$ & 0,79 \\
0,79 & 0,79 \\
$0,43+0,62 \mathrm{i}$ & 0,75 \\
$0,43-0,62 \mathrm{i}$ & 0,75 \\
$-0,56-0,42 \mathrm{i}$ & 0,71 \\
$-0,56+0,42 \mathrm{i}$ & 0,71 \\
$-0,66-0,18 \mathrm{i}$ & 0,69 \\
$-0,66+0,18 \mathrm{i}$ & 0,69 \\
0,50 & 0,50 \\
$0,14+0,46 \mathrm{i}$ & 0,48 \\
$0,14-0,46 \mathrm{i}$ & 0,48 \\
\hline $010-4$ &
\end{tabular}

Nota: 4 raízes unitárias impostas 
Tabela A.5 - Função impulso-resposta generalizada

\begin{tabular}{|c|c|c|c|c|c|}
\hline \multirow{2}{*}{$\begin{array}{l}\text { Resposta: Hiato } \\
\text { Período }\end{array}$} & \multicolumn{5}{|c|}{ Choque } \\
\hline & Hiato & Inflação & Selic & Crédito & Câmbio \\
\hline 1 & 0,0185 & 0,0074 & 0,0025 & 0,0049 & $-0,0020$ \\
\hline 2 & 0,0182 & 0,0099 & 0,0028 & 0,0014 & $-0,0054$ \\
\hline 3 & 0,0168 & 0,0101 & $-0,0016$ & 0,0010 & $-0,0077$ \\
\hline 4 & 0,0128 & 0,0083 & $-0,0066$ & 0,0002 & $-0,0096$ \\
\hline 5 & 0,0241 & 0,0094 & $-0,0030$ & $-0,0006$ & $-0,0070$ \\
\hline 6 & 0,0252 & 0,0093 & $-0,0047$ & $-0,0003$ & $-0,0088$ \\
\hline 7 & 0,0235 & 0,0109 & $-0,0047$ & $-0,0008$ & $-0,0112$ \\
\hline 8 & 0,0200 & 0,0120 & $-0,0054$ & $-0,0002$ & $-0,0125$ \\
\hline 9 & 0,0312 & 0,0172 & $-0,0014$ & 0,0026 & $-0,0082$ \\
\hline 10 & 0,0309 & 0,0179 & $-0,0031$ & 0,0039 & $-0,0068$ \\
\hline 11 & 0,0295 & 0,0184 & $-0,0050$ & 0,0033 & $-0,0099$ \\
\hline 12 & 0,0251 & 0,0178 & $-0,0065$ & 0,0019 & $-0,0127$ \\
\hline \multicolumn{6}{|l|}{ Resposta: Inflação } \\
\hline Período & Hiato & Inflação & Selic & Crédito & Câmbio \\
\hline 1 & 0,0026 & 0,0065 & 0,0016 & 0,0012 & 0,0020 \\
\hline 2 & 0,0012 & 0,0043 & 0,0009 & 0,0025 & 0,0056 \\
\hline 3 & 0,0006 & 0,0014 & 0,0001 & 0,0038 & 0,0054 \\
\hline 4 & $-0,0011$ & 0,0005 & $-0,0002$ & 0,0016 & 0,0021 \\
\hline 5 & $-0,0022$ & 0,0000 & $-0,0015$ & 0,0004 & 0,0006 \\
\hline 6 & $-0,0013$ & 0,0006 & 0,0006 & 0,0001 & 0,0019 \\
\hline 7 & $-0,0009$ & $-0,0000$ & 0,0016 & $-0,0001$ & 0,0040 \\
\hline 8 & $-0,0013$ & 0,0004 & 0,0009 & 0,0012 & 0,0042 \\
\hline 9 & $-0,0027$ & 0,0003 & 0,0008 & 0,0015 & 0,0034 \\
\hline 10 & $-0,0020$ & 0,0006 & 0,0012 & 0,0015 & 0,0030 \\
\hline 11 & $-0,0013$ & 0,0013 & 0,0009 & 0,0019 & 0,0039 \\
\hline 12 & $-0,0028$ & 0,0005 & 0,0001 & 0,0013 & 0,0042 \\
\hline \multicolumn{6}{|l|}{ Resposta: Crédito } \\
\hline Período & Hiato & Inflação & Selic & Crédito & Câmbio \\
\hline 1 & 0,0047 & 0,0034 & $-0,0068$ & 0,0177 & 0,0045 \\
\hline 2 & 0,0051 & 0,0009 & $-0,0086$ & 0,0124 & $-0,0016$ \\
\hline 3 & 0,0103 & 0,0036 & $-0,0148$ & 0,0162 & $-0,0090$ \\
\hline 4 & 0,0072 & $-0,0022$ & $-0,0232$ & 0,0145 & $-0,0123$ \\
\hline 5 & 0,0160 & $-0,0020$ & $-0,0232$ & 0,0108 & $-0,0205$ \\
\hline 6 & 0,0208 & $-0,0042$ & $-0,0284$ & 0,0091 & $-0,0239$ \\
\hline 7 & 0,0253 & $-0,0045$ & $-0,0302$ & 0,0099 & $-0,0277$ \\
\hline 8 & 0,0284 & $-0,0046$ & $-0,0342$ & 0,0094 & $-0,0354$ \\
\hline 9 & 0,0347 & $-0,0023$ & $-0,0383$ & 0,0110 & $-0,0386$ \\
\hline 10 & 0,0416 & 0,0009 & $-0,0431$ & 0,0142 & $-0,0418$ \\
\hline 11 & 0,0467 & 0,0029 & $-0,0479$ & 0,0139 & $-0,0468$ \\
\hline 12 & 0,0519 & 0,0066 & $-0,0523$ & 0,0156 & $-0,0504$ \\
\hline
\end{tabular}

